\title{
THE LANGUAGE OF LACE AND EMBROIDERY FROM THE COURT OF LOUIS XIV THROUGH TO CONTEMPORARY \\ HAUTE COUTURE
}

By

Cathrine Lloyd

\begin{abstract}
A thesis submitted to the Victoria University of Wellington in fulfilment of the requirements for the degree of Master of Arts
\end{abstract}

Victoria University of Wellington

2015 



\begin{abstract}
The history of thread work is a story of practicality and functionality, but it is also a tale of power, fashion, virtuosity, decorum, art and culture. Thread work has played a role as a visual language in France for many centuries, continually evolving in its techniques and range of expressive and stylistic possibilities and thus in its significance as a communicative medium. In more recent times, thread work has come to be considered as a form of social and cultural discourse in its own right that is consequently referred to as 'visual rhetoric'. Following this unique form of visual discourse through the history of fashion allows consideration of the development of identity and gender roles in French society as well as the interrelated narratives of the creative processes involved in the production of lace and embroidery. These reflections lead in turn to consideration of the ways processes of production and consumption were disrupted and transformed by major events, by sumptuary laws and political edicts. The language of thread work has been encoded and decoded by all socio-economic classes, and is underwritten by tensions between power and dependency, rich and poor, light and dark, public show and private domesticity. It has the capacity to express identities and to enhance communities. In more recent times the reconsideration of the value of thread work in the design concepts of haute couture has seen a revitalisation of the appreciation of this medium in an industry associated with luxury, exclusivity and creativity. The language of thread-work remains ambivalent and complex in France today, signifying an innocuous 'feminine' pastime on the one hand, and a valued professional skill and cultural heritage on the other.
\end{abstract}




\section{Acknowledgements}

I wish to thank first and foremost my supervisor, Dr Keren Chiaroni, who has been my friend and mentor for many years. Her appreciation of my work as a practitioner of embroidery and lace has encouraged me to widen my knowledge in the field of academic research, which has consolidated and stimulated my passion for thread work. Throughout many years of French study, culminating in this thesis, Dr Chiaroni has been an encouraging and inspirational teacher.

I would like to thank Victoria University for assisting me to travel to Paris to further my research.

I would also like to thank Jean Anderson for her support and patience. Thank you also to my family who have always encouraged me in my endeavours. Thank you to my daughter Jen, for her proof reading and advice, and my husband Nigel for his ongoing support for my belief in life-long learning. 


\section{Table of Contents}

Table of Figures............................................................................................. vii

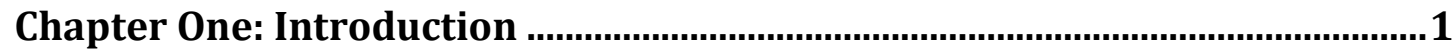

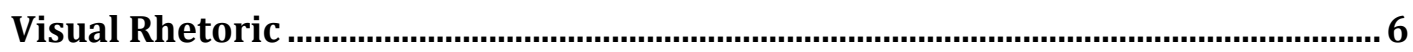

Chapter Two: Interwoven Narratives of the Materiality and Fabrication of

Embroidery and Lace. .................................................................................... 13

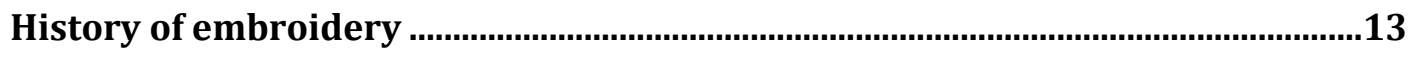

Origins of Lace

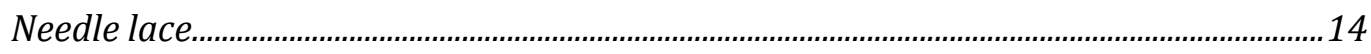

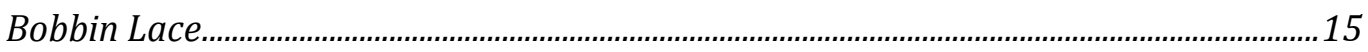

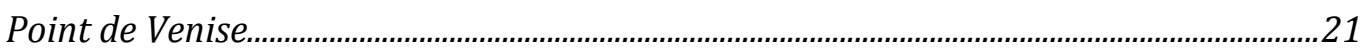

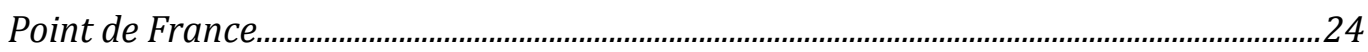

Who did the work?

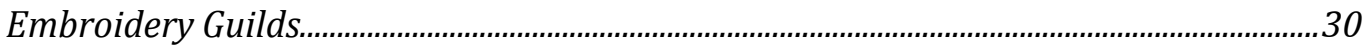

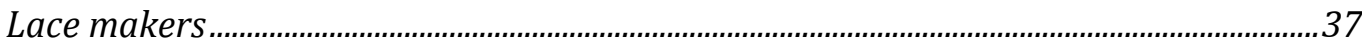

Colbert's Sponsorship of the Lace Industry …......................................................

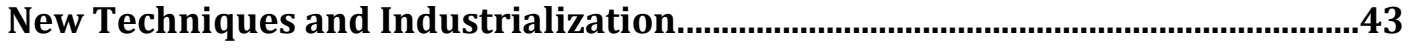

Chapter Three: The Language of Power .......................................................... 45

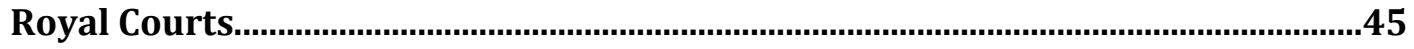

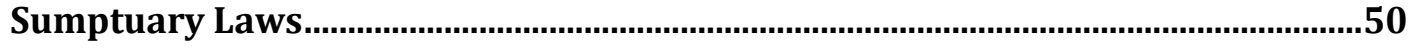

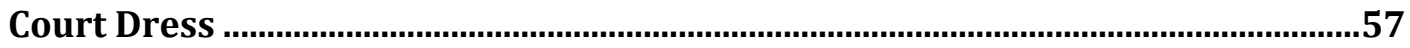

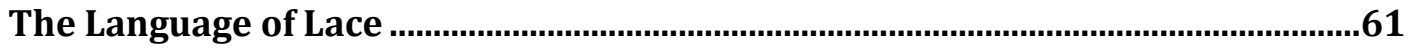

Representation of Lace and Embroidery in Paintings............................................66

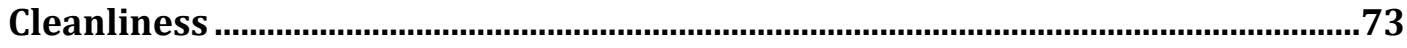

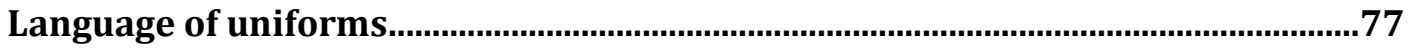

Chapter Four: Changing Attitudes and the Domestication of Needlework 83 Changing Representations: The new language of lace and embroidery in

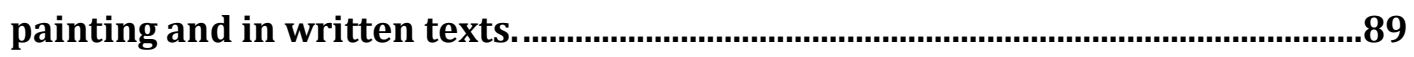

Chapter Five: Patterns of Identity ..............................................................101

Breton Costume

Chapter Six: The Language of Haute Couture: the Expression of Excess in a

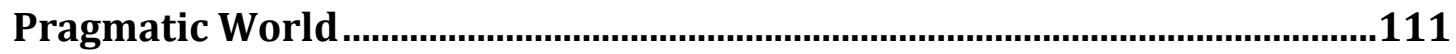

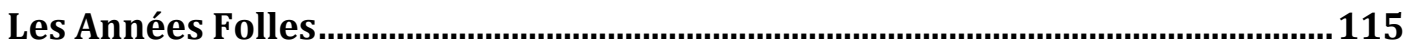




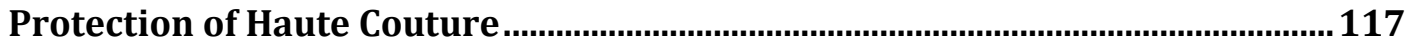

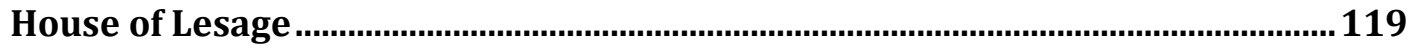

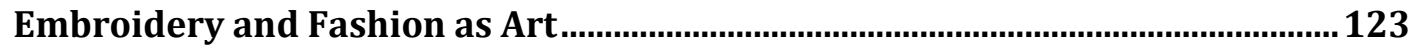

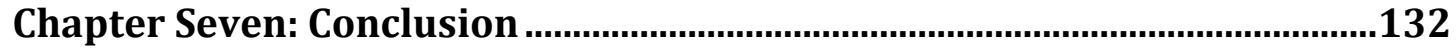

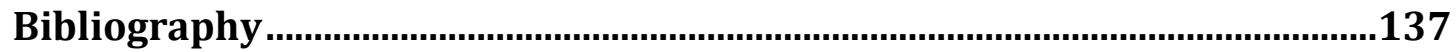




\section{Table of Figures}

Figure 1. Illustration of bobbin lace technique, Encyclopédie, ou dictionnaire raisonné des sciences, des arts et des métiers, Diderot, Denis and Jean le Rond d'Alembert Vol. 20 page 21:1. ARTFL Encyclopédie Project. ...

Figure 2. Diagram of techniques of bobbin lace, Encyclopédie, ou dictionnaire raisonné des sciences, des arts et des métiers, Diderot, Denis and Jean le Rond d'Alembert Vol. 20 page 21:1. ARTFL Encyclopédie Project....................... 18

Figure 3. Federico Vinciolo, Les singuliers et nouveaux pourtraicts, 1587, 42........19

Figure 4. Bartolomeo Danieli, Design pattern, 1639. Etching, 34 x 49cm. New York, Metropolitan Museum of Art.

Figure 5. Point de Venise border of needlelace, 17th century. 306.1 x $20.3 \mathrm{~cm}$.

Metropolitan Museum of Art

Figure 6. Pierre-Imbert Drevet, Bishop Jacques-Benigne Bossuet, 1723. engraving, 509 x 307mm. London, The British Museum. (C) Trustees of the British Museum. 25

Figure 7. Cravat End with monogram of Louis XIV, Bobbin lace, point d'Angleterre, Brussels, 1675-1715. Art Institute of Chicago 26

Figure 8. Saint-Aubin, Augustin de, Un atelier de broderie, 18th century. Black and brown ink drawing, 0.123 x $0.223 \mathrm{~m}$. Paris, Musée du Louvre, RMN.

Figure 9. Jacques Launosnier, Entrevue de Louis XIV de France et de Philippe IV d'Espagne dans l'Île des Faisans en 1659, 17th century. Oil on canvas, 89.1 $\times 130 \mathrm{~cm}$. Mans, Musée de Tessé

Figure 10. Nanteuil, Louis XIV, 1664. Engraving, Bibliothèque de France

Figure 11. Hyacinthe Rigaud, Louis XIV, 1702. Châteaux de Versailles et de Trianon, Paris

Figure 12. Antoine-François Callet, Louis XVI, King of France and Navarre, 1789. Oil on canvas, 278 x $196 \mathrm{~cm}$. Châteaux de Versailles. 68

Figure 13. François-Hubert Drouais, Portrait of Madame Pompadour at her Tambour Frame, 1753. Oil on canvas, 217 x $156.8 \mathrm{~cm}$, London, National Gallery .70 
Figure 14. Tocque Louis, Madame Dangé faisant les næuds, 1753, Oil on canvas, $0.83 \mathrm{~m}$ x $0.63 \mathrm{~m}$, Paris, Musée du Louvre.

Figure 15. One of a series of seven embroidered bees, thought to be destined for the Throne room at Fontainebleau, 19th century. Gold threads on canvas, 0.15m x 0.95m. Rueil-Malmaison, chateaux de Malmaison et Bois-Préau. ORMN 80

Figure 16. Jean-Baptiste-Siméon Chardin, The Embroiderer, 1736. oil on canvas, 15.5 x $19 \mathrm{~cm}$. National Museum, Stockholm, Sweden. 89

Figure 17. Jean-Baptist-Siméon Chardin, Young Draughtsman copying an Academy, 1736. Oil on canvas, 15.5 x $19 \mathrm{~cm}$. National Museum Stockholm. 89

Figure 18. Jean-Baptiste-Siméon Chardin, La Mère laborieuse, 1740. Oil on canvas, 39 x 49 cm. Paris, Musée du Louvre.

Figure 19. Paul Poiret, fancy dress costume designed and worn to the mille et deuxième nuit party, 1911. Metal, silk, cotton, Length $127.6 \mathrm{~cm}$, diameter $20.6 \mathrm{~cm}$. New York, Metropolitan Museum of Art.

Figure 20. Women's Evening Coat, designed by Elsa Schiaparelli. Designed in collaboration with Jean Cocteau. Embroidered by Lesage, Paris, Fall 1937. Rayon knit, silk and gilded metallic thread embroidery, silk appliquéd flowers. Centre Back Length: $147.3 \mathrm{~cm}$. Philadelphia Museum of Art: Gift of Mme Elsa Schiaparelli, 1969

Figure 21. Woman's Dinner Jacket, Designed by Elsa Schiaparelli, Designed in collaboration with Jean Cocteau, Embroidered by Lesage, Paris French, Fall 1937. Linen plain weave, gilded metallic and silk thread embroidery, beads, and paillettes. Waist: $71.8 \mathrm{~cm}$. Center Back Length: $52.7 \mathrm{~cm}$. Circumference (Bust): $87.6 \mathrm{~cm}$. Hips: $90.2 \mathrm{~cm}$. Philadelphia Museum of Art: Gift of Mme. Elsa Schiaparelli, 1969 


\section{Glossary and Abbreviations}

Basque

Bigoudène

Bobbin lace

Compagnon

Cordonnet

Cut Work

Filet

Frac

Galloon

Glazic

Goffering iron
Bodice or jacket of women's clothing

Regional embroidery from the region of Pont-l'Abbé, Brittany.

Generic term for lace made by plaiting and twisting together a number of threads wound on small bobbins and secured at the upper ends to a hard pillow.

A male embroiderer who has completed his apprenticeship and is working towards becoming a Maître. This professional formation took three years.

A core of threads covered with close button-hole stitches, forming the reliefs of a needlelace.

From the $16^{\text {th }}$ century, a generic name for all needlelace based on a woven net background.

Handmade knotted net, often embroidered.

Man's long frock coat, with long sleeves.

Decorative woven trim in the form of a braid.

Regional embroidery of Quimper, Brittany.

Metal rod, the size of a test-tube, or iron, used to make pleats in ruffs. 
Grand habit du cour

Habit habillé

Lacis

Lunéville

Lunévilleuses

Maintenuese

Maître

Needle lace

Nœuds

Paillette

Parure
A bare shouldered dress worn by women at the court of Louis XIV. It comprised of a heavily trimmed skirt with a long train, a boned bodice and puff sleeves.

Elaborate silk or velvet coat, worn by men at the court of Louis XIV, often covered in embroidery and jewellery.

Old technique in which hand-made knotted net is decorated with embroidery.

Or point de Lunéville, is a form of applied embroidery by which beads and sequins are fastened to a ground material with a tambour hook.

Women that make embroidery with a hook using the Lunéville technique.

Women that make embroidery by hand.

Highly skilled master embroiderer who owns his own atelier and is able to train apprentices.

Generic term for all forms of open work constructed stitch by stitch with a needle and thread.

Knots. A popular pastime in the seventeenth and eighteenth century was making knots using a shuttle. These knots, when arranged closely together, formed a braid which could then be applied to fabric.

Ring of flattened gold with a small hole in the middle for stitching to fabric. Equivalent to contemporary sequin.

Adornment. 
Passementerie

Point

Reticella

Tambour

Thread work
The art of making elaborate trimmings or edgings of applied braid, gold or silver cord, embroidery, colored silk, or beads.

French term for stitch.

A form of cutwork in which threads were pulled from linen fabric to make a "grid" on which the pattern was stitched, primarily using buttonhole stitch. Later reticella used a grid made of thread rather than a fabric ground. Both methods resulted in a characteristic geometric design of squares and circles with various arched or scalloped borders.

A type of circular embroidery frame.

Lace and embroidery made by hand, including bobbin lace and needlelace. 


\section{Chapter One: Introduction}

Thread work has played a role as a visual language in France for many centuries, continually evolving in its techniques and range of expressive and stylistic possibilities. The history of thread work, defined as hand embroidery, needle lace and bobbin lace, is a story of practicality and functionality. But it also resonates with ideas of power, fashion, virtuosity, decorum, art and culture. As such, the discourse of lace and embroidery implicates all members of society - the privileged and the marginalized, the wearers and the weavers of the fabric of the tale. The visual rhetoric of lace and embroidery thus offers unique insights into some of the stories a society tells about itself and has fabricated with skill and virtuosity.

Dress in the late seventeenth century where my research begins, was directly related to social position. People believed that association with the king and his supreme power could elevate them to a higher social level. ${ }^{1}$ Accordingly, sartorial grandeur was a key factor in social differentiation, and conforming to and understanding its language was essential to one's political survival. Lace and embroidery were an integral part of this dress culture. They were an omnipresent feature of costume throughout the century and operated as a potent sign within accepted dress codes. Their meaning was layered, and composed of several different strands, or sub-texts. Where the manufacture of thread work relied on the lower classes, its commercial success depended on the merchants who handled and sold it, while its consumption

\footnotetext{
${ }^{1}$ Edward Maeder, "The Elegant Art of Dress," in An Elegant Art: Fashion and Fantasy in the Eighteenth Century, ed. Phil Freshman (New York, Harry N. Abrams Inc., 1983), 15.
} 
depended on the aristocracy who bought and wore it. It was, after all, the most expensive of items and only the aristocracy and the high-ranking clergymen could afford it.

In this research I propose to examine a very particular 'text' of complex pleasures and simple practicality: the language of lace and embroidery from the court of Louis XIV through to the re-emergence of a comparable discourse of hand-worked luxury in twentieth-century haute couture. Exploration of this unique form of visual discourse in French fashion history allows us also to consider questions of identity and gender roles in French society, and the interrelated narratives of production and consumption over time. Selected examples of thread work included in this research are derived from museum collections and archival holdings, while others are derived from the representations of thread work in historical paintings. Royal portraits, in particular, demonstrate how lace and embroidery have been an integral part of the portrayal of status and power for centuries. Thread work was used symbolically and was highlighted in great detail in many of these portraits, which could then be used as a dazzling yet carefully 'phrased', or 'worded', form of political propaganda. One of the difficulties in researching lace and embroidery in this way is that the work was often alluded to only briefly in written descriptions, while its makers were rarely named. Elizabeth Walsh insists, however, that portraits remain a valuable source of information for the researcher requiring only sensitive de-coding to reveal their rich significance:

Material goods are mute but they can still be interpreted when aided by an array of written and visual evidence and approached with care. Furthermore, when 
they are better understood, such objects can create a resonance....a sort of harmony of intention. ${ }^{2}$

Consideration of these material objects enables a fuller appreciation of the semantics of the designs, as well as the 'messages' involved in the production and reception of thread work.

Just as each individual word is significant in the composition of a phrase or a sentence, so the narrative of each part of the story of lace and embroidery adds complexity to the sign language of this unique visual discourse. The narrative of the fabricators of the lace, for example, is a reminder that this is a tale not just of hierarchies but also of hiddenness. For lower class women were often the invisible and anonymous producers of commercial work by contrast with the aristocratic women who used the creation as well as the consumption of thread work to overtly demonstrate their refinement and education. The tension between rich and poor, the light of the mirrored hall at Versailles compared to the workplaces where lace was made in near total darkness in order to conserve the thread, the visual prominence of the aristocracy in society versus the invisibility of those who created their spectacular finery - these are all persistent and recurring threads in a history as textured as the material it purports to represent.

The fabricators of this material history have ensured that brilliance was not only the province of the wearers of lace and embroidery. Virtuosity in execution of thread

\footnotetext{
${ }^{2}$ Walsh, "Gros point de Venise: Lace and its Representation 1660-1702," (PhD diss., University of East Anglia, 2009), 14.
} 
work has demonstrated a luxuriance of detail and technique as dazzling as any court dress, as professional thread workers made full use of the different ways of making marks or meaning in stitch work. These markers are as infinite as those used in verbal discourse. Threads of different colours, stitches of different complexities, the use of different instruments and needles in fabrication, various fabrics and ways of treating it, and the combination of each of these variables, all offered the skilled embroiderer and lace maker an infinite number of ways of constructing meaning even without explicit reference to symbols or pictorial images. As Jennifer Wearden affirms:

Given technical ability, the effects that can be created through embroidery are almost limitless. While each stitch or group of stitches have their own qualities and characteristics, it is the embroiderer's ability to select and exploit them that will transform a plain piece of fabric into a pleasing and unique work of art. The power to perform magic with a needle comes through the embroiderer's familiarity with stitches: with their structure, with the hand movement required to make them and with their seemingly infinite variation. $^{3}$

In short, fluency in the language of thread work, like fluency in the language of words, facilitates more complex and subtle forms of communication. The skill of the fabricator is thus an essential part of the discourse of thread work as is consideration of how and where it was made. The consumer, or wearer of the garment, naturally contributes further shades of meaning to the 'message', depending on how, when and

\footnotetext{
${ }^{3}$ Jennifer Wearden, "Stitches and Techniques," in Samplers from the Victoria and Albert Museum, ed. Browne and Wearden, (London: V\&A publications, 1999), 129.
} 
where the garment is worn, and the social ritual the wearer engages in. In turn each 'reader' or observer of the ritual may then perceive the message differently according to his or her own life experiences and cultural influences. ${ }^{4}$

I have chosen to draw on the thread work of embroidery and lace for the purposes of this research, largely because embroidery is the precursor of lace and is thus inseparable from it in historical terms. At the same time I have framed my research with exclusive reference to the use of thread work in dress and clothing, rather than in furnishing or spatial design. The definition of the central term of lace includes reference to its fabrication with a needle, known as needle lace, and with a bobbin, where the lace is produced through manipulation and twisting of threads, known as bobbin lace. Because of the inclusion of bobbin lace, which is made without a needle, the preferred term in this research is 'thread work,' rather than needlework, which is commonly associated with embroidery.

Appreciating the language of thread work necessitates the study of the specific materiality of certain cultural artefacts. The references here to 'discourse' and 'rhetoric' are not, therefore, proposing a reading of abstract, or self-referring signs. Rather, attention is focused on a language inseparable from the conditions in which it has evolved and the purposes for which it was created. Signifier and signified have been connected in precise ways and with conscious care and skill.

${ }^{4}$ Foss, Sonja K. "Theory of Visual Rhetoric." in Handbook of Visual Communication: Theory, Methods, and Media. ed. Ken Smith, Sandra Moriarty, Gretchen Barbatsis, and Keith Kenney. (Mahwah, New Jersey: Lawrence Erlbaum, 2005), 147. 


\section{Visual Rhetoric}

Much research has been undertaken on the history and techniques of the fabrication of embroidery and lace throughout the centuries. In more recent times, thread work has been recognised as a form of social and cultural discourse in its own right, referred to as 'visual rhetoric'. This is a relatively new term to the history and study of thread work and has been controversial amongst academics. Traditionally, rhetoric had been considered the domain of verbal discourse, relating especially to the power of speech. Through the power of speech the orator has the capacity to persuade, inform, influence and motivate his or her listener. Roland Barthes, French philosopher and semiotician, began to contest the narrowness of this frame of reference and its underlying assumptions in his early work Mythologies ${ }^{5}$, published in 1957. This book was a compilation of monthly essays written by Barthes to highlight the use of secondary signifiers, or connotations, as they were embedded in the myths of everyday life in France. For example, a full bottle of red wine is on one obvious level a signifier that correlates directly to the actual signified image, i.e. a bottle of alcohol, but there is also a secondary connotation involved that transmits the message of wine as part of the French lifestyle, with associated qualities of health, vigour and strength. This focus on the readability of images laid the groundwork for new ways of reading popular culture. And it introduced techniques of analysis that could be applied to thread work, both historical and contemporary.

Following Barthes' lead, researchers during the 1970s widened the scope of cultural reading to include diverse areas such as photography, art, embroidery and lace, all of

\footnotetext{
${ }^{5}$ Roland Barthes, Mythologies, (Paris: Éditions du Seuil, 1957).
} 
which came to be considered as equally valid examples of visual rhetoric. The primacy of speech was thus overtaken by the key notion of discourse that was adapted to the visual image mediums of advertising, film, internet and television, which were becoming increasingly dominant forms of popular culture. Film in particular became a favourite terrain of study since the films could be viewed from a wide range of cultural and aesthetic perspectives. The language of thread work has sometimes been considered as a vocabulary subset within the visual rhetoric of film. This is partly because of the role costume plays in a dramatic medium that allows for close-ups and manipulation of the body of the actor through special effects. In particular, the close scrutiny of costume that film permits means that actors as well as designers may be more conscious of the ways in which their apparel might be interpreted.

Jean-Jacques Annaud relates the response of one of the actors in the 1992 film L'Amant, to the embroidery used in the creation of his original costume:

Pour le marié, Yvonne Sassinot de Nesle avait préparé un grand costume entièrement brodé, souligné d'une ligne de chevrons, symbole du neuvième ordre des Mandarins - ordre le plus bas, certes, mais ici seulement destiné à marquer la munificence de la famille du Chinois. Or Tony Leung refusa catégoriquement de le porter, arguant de ce que ni lui ni son personnage n'étaient des mandarins: la symbolique demeure vivante! On dut coudre sur les chevrons une bande brodée de symboles plus profanes comme les caractères de la longévité..... ${ }^{6}$

\footnotetext{
${ }^{6}$ Yvonne Sassinot de Nestle, Les fables du vêtement, Musée d'Art et d'Industrie de Roubaix, (Campin, 1995), 12.
} 
The symbolism of the chevron design was perceived by actor Tony Leung as connoting a completely different message to the one appropriate to his character, and especially to himself, as the actor playing the character. This message was one received and experienced through his Chinese heritage, as distinct from mainstream French culture. His reading of the detail of the embroidery, detail that could also be seen and appreciated by viewers, was very different from that of the French costumier and the film crew. A modification was therefore introduced into the design that allowed for a more appropriate 'close reading' of the costume's discourse. The incident serves as a reminder that symbols are woven into an individual cultural language that may not be understood by everyone in the same way. As in verbal, so in visual language, we need keys to be able to decipher images that are 'foreign' to us.

At the same time, great pleasure is derived from observing the juxtaposition of different signs, not all of which we immediately recognise or are familiar with. Barthes' observations in Le Plaisir du texte ${ }^{7}$, suggest that awareness of ambivalence in multi-accented texts is as important as the ability to 'read' the signs with which we are more immediately familiar. Complexity in rhetoric, and the need for careful deciphering, adds mystery to the pleasure of reading, and so extends and prolongs the 'pleasure' of the text. Barthes explains it thus:

Alors le vieux mythe biblique se retourne, la confusion des langues n'est plus une punition, le sujet accède à la jouissance par la

\footnotetext{
${ }^{7}$ Roland Barthes, Le Plaisir du texte (Paris: Éditions du Seuil, 1973).
} 
cohabitation des langages, qui travaillent côte à côte: le texte de plaisir, c'est Babel heureuse. ${ }^{8}$

One of the challenges of this research has been to understand as much as possible some of the rhetorical responses to lace and embroidery at the time of their production. ${ }^{9}$ Barthes' reading of signs implies privileged readings of certain social messages for a privileged class who, in the following passage, are the colonizing French, speaking their language of imperialism:

Je suis chez le coiffeur, on me tend un numéro de Paris-Match [1957]. Sur la couverture, un jeune nègre vêtu d'un uniforme français fait le salut militaire, les yeux levés, fixés sans doute sur un pli du drapeau tricolore. Cela c'est le sens de l'image. Mais, naïf ou pas, je vois bien ce qu'elle me signifie : que la France est un grand empire, que tous ses fils sans distinction de couleur, servent fidèlement sous son drapeau... ${ }^{10}$

Barthes' comments regarding the cover of the Paris Match magazine of June 26, 1955, illustrate how the denoted implication of an image, in this case, a 'negro' saluting the French flag, is not immediately distinguishable from its ideological meaning or 'hidden' signification, namely that France is a great Empire. While the image appears neutral the combination of signifier and signified effectively perpetuates the myth of imperial devotion. In this way, the dominant culture can

\footnotetext{
${ }^{8}$ Ibid., 10.

${ }^{9}$ Ibid., 145.

${ }^{10}$ Barthes, Mythologies, 116.
} 
impose its values through the potency and ubiquitous quality of myth. And myth, unthinkingly consumed, becomes 'reality'.

But are all examples of thread work recognizable as visual rhetoric in this way? Sonya Foss names three features essential to its being received as such, namely: (a) the image must be symbolic, (b) it must involve human intervention and, (c), and it must be presented to an audience for the purpose of communicating with that audience. $^{11}$

Samplers, or essamplaires from the seventeenth century certainly met these three criteria. Produced as a demonstration of skill, dexterity and innovation, these embroidered pieces of fabric were used as a dictionary of stitches and effects. They served as "crucial spaces for developing and sustaining the complex domain and procedural knowledge of thread work". ${ }^{12}$ Firstly, symbolic messages were constructed with great deliberation and deciphered with care by those who valued them. Secondly, a conscious decision was made by the needle-worker to use a certain thread, colour and stitch in order to produce an effect in the sampler. While the needle worker's desire for self-expression may have been a major motivator in the work's production, they made decisions on the choice of materials and how they were placed, even if they alone were the only ones who witnessed and comprehended these decisions - making them a privileged audience of one. The samplers clearly involved human intervention as they were stitched by hand. Thirdly, the samplers were commonly used as a source of inspiration from one generation to the next, suggesting

\footnotetext{
${ }^{11}$ Foss, "Theory of Visual Rhetoric", 144.

12 Ibid., 91.
} 
their message had been successfully communicated and understood. At the same time the embroiderer's individual samplers, or 'phrase books' of stitching, were often used as inspirational sources for other kinds of art and handwork, including parures and textiles.

By the late eighteenth century however, some of the embroidered samplers could not be considered visual rhetoric according to Foss' criteria. Often, they were viewed as an end in themselves, delighting because of their colour, texture and pattern and having no other purpose than to please the eye. Samplers were produced that were stitched using only one stitch, for example, predominantly cross stitch and the completed item had no encoded message. It formed a simple picture or carried a banal message, the whole having been produced for its aesthetic qualities, so that the embroiderer could enjoy the meditative practice of fabricating it and the pleasure of accomplishment. In this respect, such samplers differed from the original samplers of the seventeenth century, while anticipating an approach to thread work that is often associated with the twentieth and twenty-first centuries, and with Barthes' Le Plaisir du texte, as distinguished from his more carefully decoded Mythologies.

From the 1790s onwards, embroidery and lace were subjected to the transformative power of revolution: political revolution, fashion and consumer revolution and industrial revolution. Each of these major upheavals played a part in the eventual demise of lace and embroidery as a language of power, as expressed principally in the royal courts. Embroidery nonetheless survived the challenges of these revolutions through the audacious creativity associated with the designers of haute couture. Today the reconsideration of the value of thread work in haute couture has helped revitalize the medium. Skilled embroiderers of these exclusive high-fashion garments 
use the reflective qualities of sequins and thread in a way that recalls the Court of Louis XIV, where light from hundred and thousands of candles was reflected off the smooth threads of silk and linen, the spangles and paillettes sewn into the courtiers' grande tenue. Haute couture, however, like Barthes' vision of Babel in Le Plaisir de texte, should be read primarily not as a form of historic representation but as a sequence of allusions, a complex rhetoric of fantasy. Once the onlooker learns how to move beyond the expected meanings and narratives of the dress code, and into the realm of the language of thread and fabric for their own sake, they are set adrift on a sea of signifiers. As in oral language, so in the vibrant language of thread work, there are unexpected touches and highlights, painstakingly produced and provocative in effect: "dans certains textes, des mots brillent, ce sont des apparitions distractives, incongrues - il importe peu qu'elles soient pédantes... ${ }^{13}$

\footnotetext{
${ }^{13}$ Barthes, Le Plaisir du texte, 68.
} 


\section{Chapter Two: Interwoven Narratives of the Materiality and Fabrication of Embroidery and Lace.}

While the origin of lace is to be found in the techniques of embroidery, historically their commercial fabrication took diverse pathways. Embroidery was controlled by the traditional patriarchal guild system, while lacemaking developed independently as a women's trade. Embroidery was undertaken by men as the Maîtres, compagnons and apprentices of the workshops and by female family members and women often illegally employed. Some embroidery work was also undertaken in convents. Lace, on

the other hand, was only made by women. Consideration of the production and materiality of thread work assists in an appreciation of the contribution of the original fabricators. These fabricators played an important part in the construction of the visual rhetoric that embroidery and lace portrays. By using different designs, materials, techniques, and applying symbolism into their work, the message became more rich and complex. The history of its production also sheds light onto the gendered economy that resulted, and which in turn developed an association of thread work with femininity and ultimately domesticity.

\section{History of embroidery}

The history of embroidery begins many centuries before that of lace. The embroideries of the medieval period were mainly fabricated for ecclesiastical settings where stories of saints and martyrs were pictorially depicted for the benefit of an illiterate population. Rich gold and silver threads were often used in these literal representations in order to communicate the church's teaching and to underline at the 
same time the church's power and wealth. During the sixteenth century, embroidery began to be applied to more secular projects and the use of it as a highly valued adornment soon became widely apparent. Even though it was controlled by a guild structure, which consisted of large numbers of embroidery ateliers, other workshops were also established, for example, in convents and charitable institutions, to keep up with demand. ${ }^{14}$

\section{Origins of Lace}

There are essentially two different kinds of lace, identified according to the technique and origins involved in their fabrication. Needle lace has evolved from embroidery and bobbin lace has evolved from passementerie, the art of plaiting or weaving together of threads to form a braid or embroidered trimming. ${ }^{15}$

\section{Needle lace}

Needle lace originated around 1540, from the work of Venetian embroiderers who extended the concept of drawn thread work or cutwork $^{16}$ to produce a skeletal woven fabric called punto in aria or 'stitches in the air'. To achieve these 'airy' stitches, threads were laid down in a geometric pattern on a backing of parchment. These threads were then worked over and connected one to another. On completion the thread work was separated from the parchment, giving the impression of something that had been made without a background, hence the name punto in aria. Lacis, a

\footnotetext{
${ }^{14}$ Hélène Farnault, Haute Couture Ateliers (London: Thames and Hudson, 2014), 97.

${ }^{15}$ Kraatz, Lace: History and Fashion (New York: Rizzoli International Publications, 1989), 12.

${ }^{16}$ Cutwork, point coupé, originally an appliqué of cut out shapes, the name was transferred to embroidery in which parts of the ground were cut away. From the mid-sixteenth century, it was the generic name for all forms of needle-lace based on a woven ground.
} 
form of darned netting and reticella, a form of needle lace, were sixteenth century techniques developed from this basic premise. ${ }^{17}$ Both were patronized lavishly by Catherine de Médici, Queen Consort of France to Henry II. Increasingly, fabric was being created where the voids were equally as important as the threads and where the spaces helped delineate the sections of a coded message.

\section{Bobbin Lace}

The guild of passementiers began using bobbins in lace production around the same time that needle lace was being fabricated, namely, in the first half of the sixteenth century. Practitioners would weave ribbons, galloons and other edgings on a loom, or plait them on long cushions, using pins to cross over the threads. They would then wind the threads onto wooden spools, or bobbins, to prevent them from getting tangled. Often called passemens, bobbin laces of the sixteenth and seventeenth century were lighter than the needle laces and were accordingly used to edge ruffs and to form borders. ${ }^{18}$

Some of the techniques of bobbin lace were illustrated in Diderot's L'Encyclopédia ${ }^{19}$ (See Fig.1 and 2). Figure one illustrates the technique of plaiting threads, without a needle. Figure two illustrates how they are a distinct series of specific patterns, which confirms the notion of lace as a readable "coded" language. ${ }^{20}$ The passementiers

\footnotetext{
${ }^{17}$ Kraatz, Lace: History and Fashion, 12.

${ }^{18}$ Ibid.

${ }^{19}$ Denis Diderot, Jean Le Rond Alembert and Pierre Mouchon, Encyclopédie: ou, Dictionnaire raisonné des sciences, des arts et des métiers, 1751-1772 (Geneve: Pellet, 1777).

${ }^{20}$ Diderot, Denis and Jean le Rond d'Alembert Encyclopédie, ou dictionnaire raisonné des sciences, des arts et des métiers, etc., eds. University of Chicago: ARTFL Encyclopédie Project (Spring 2013 Edition), Robert Morrissey (ed). http://encyclopedie.uchicago.edu/
} 
wanted to keep a monopoly on the production of bobbin lace, but felt it was beneath them to use white linen thread in their work, as one of their most important privileges accredited to passementerie guild members was the right to use precious metal threads. Hence, women took over the role of lacemaking and became independent of the all-male guilds of passementerie and embroidery. Lace evolved from the embroidery techniques of this period and went on to rival embroidery in popularity and value as a commodity in the seventeenth and eighteenth centuries. The courts of Louis XIV and Louis XV were the apogee for both embroidery and the lace techniques it generated.

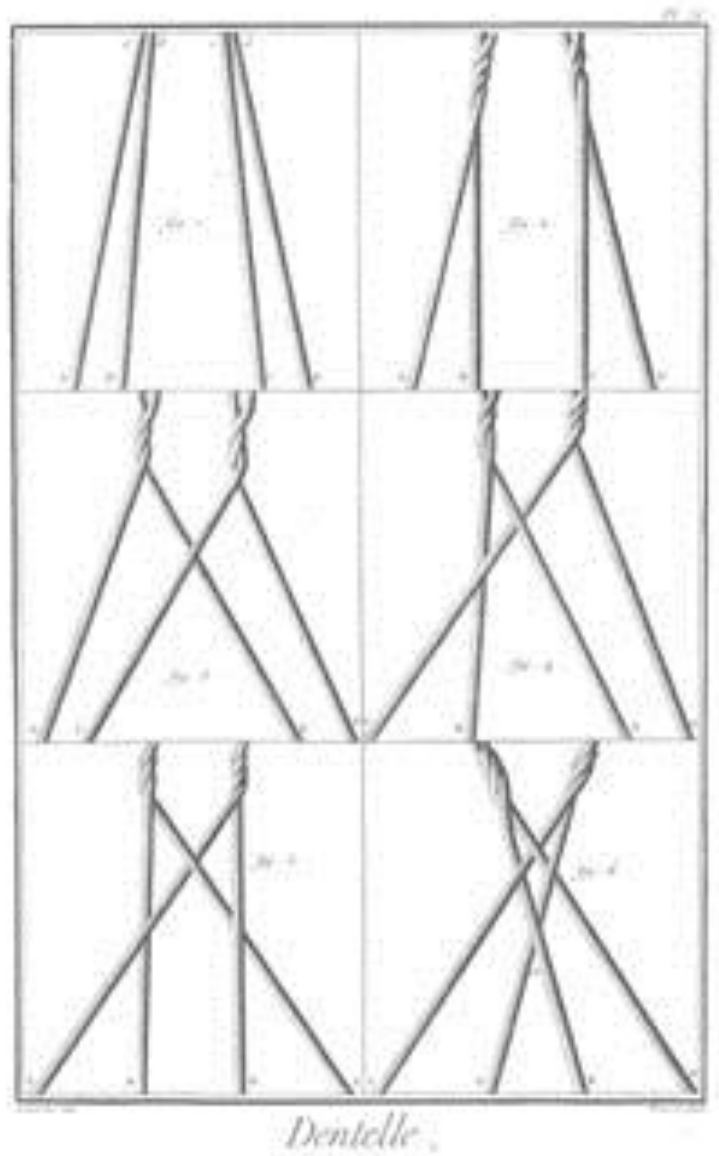

Figure 1

Illustration of bobbin lace technique, Encyclopédie, ou dictionnaire raisonné des sciences, des arts et des métiers, Diderot, Denis and Jean le Rond d'Alembert vol. 20 page 21:1. ARTFL Encyclopédie Project. 


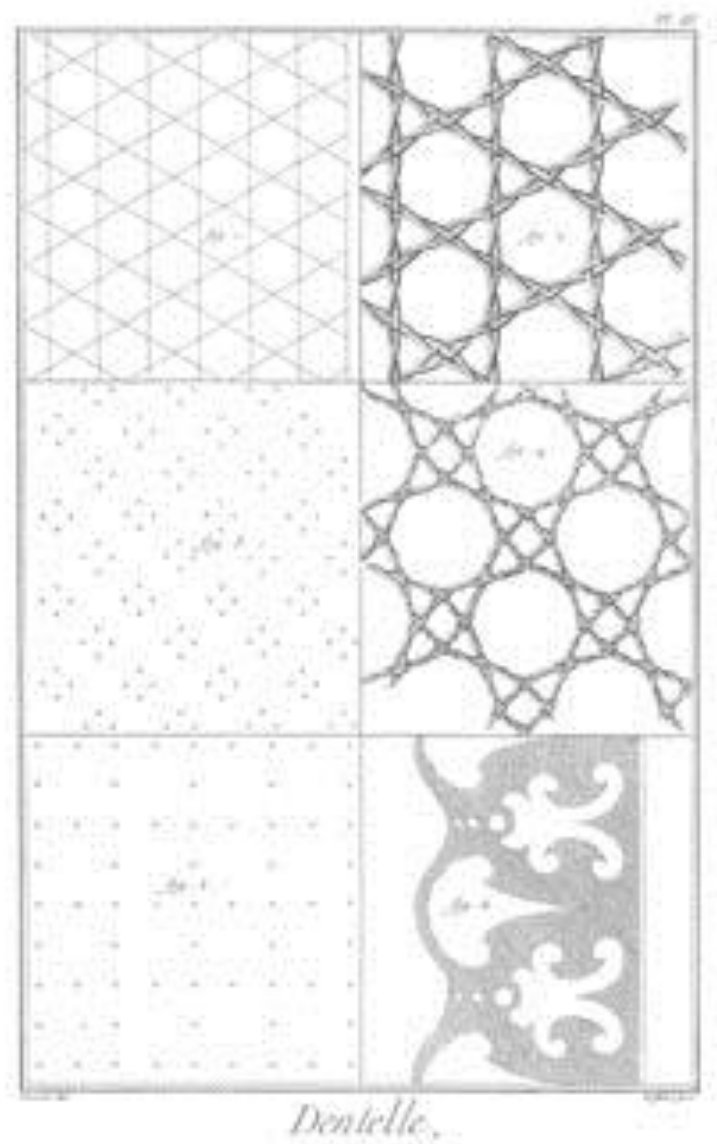

Figure 2.

Diagram of techniques of bobbin lace, Encyclopédie, ou dictionnaire raisonné des sciences, des arts et des métiers, Diderot, Denis and Jean le Rond d'Alembert vol. 20 page 21:1. ARTFL Encyclopédie Project.

\section{Symbolism in Design}

The language of lace and embroidery, used as a tool for communication and a form of visual rhetoric between people and groups, derives its signification primarily from the symbolism of its design. These patterns, often symbolic but also following fashion trends of the time, were published in the sixteenth century by recognised artists of the time. The first pattern books, such as Federico Vinciolo's Renaissance Patterns for 
Lace Embroidery and Needlepoint, published in $1587,{ }^{21}$ presented mainly geometric designs: stars, rosettes, triangles and squares, simple designs influenced by the degree of difficulty of manipulating the threads. (See Fig. 3). Some included animals, flowers and scrolls but these were always enclosed within a geometric framework.

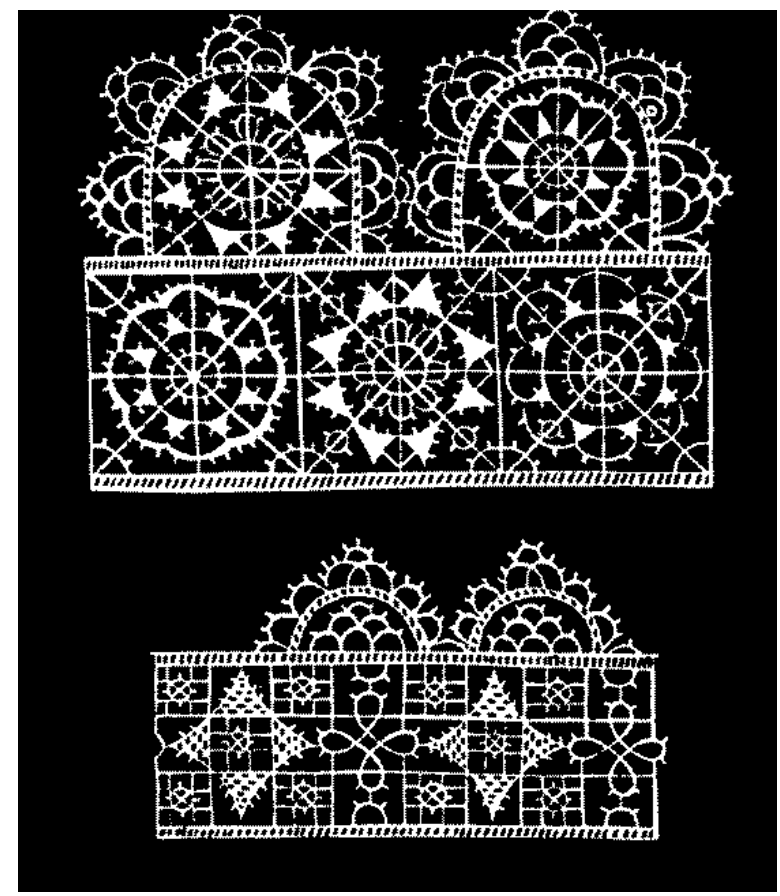

Figure 3 .

Federico Vinciolo, Les singuliers et nouveaux pourtraits, 1587, 42.

The design in Fig. 3 shows an original needle lace pattern designed by Vinciola, a seventeenth century designer, illustrating a pattern that would be suitable for punto in aria lace or embroidery. Catherine de Médici thought so highly of Vinciolo that she brought him to France and gave him the exclusive right to manufacture the enormous starched ruffs (fraises), which the Italian queen had made fashionable in Paris.

\footnotetext{
${ }^{21}$ Federico Vinciolo, Les singuliers et nouveaux pourtraits. Translated by Stanley Applebaum (New York: Dover Publications, 1971).
} 
Embroidery on the other hand was following a different design pathway and followed the fashionable idioms prevalent in other decorative arts, for example symbols of 'grotesques', the rediscovered Roman form of decoration that combined ornamental arrangements of foliage and garlands with images of cupids, fantastic animals, and scrolls. The symbolic and geometric designs of these Renaissance pattern books were easily translated into filet embroidery, a needle lace that was a form of decorative netting, but many large works of filet were not considered authentic as laces for technical reasons - the fact that the background net was often embroidered using a shuttle. Larger works were also more serious in subject matter, the fanciful cupids being replaced by biblical scenes and mythology. ${ }^{22}$ The techniques required to produce fine baroque style designs in lace were not yet evident.

Kraatz suggests that this universally accessible language of linear motifs allowed for the dissemination and increasing popularity of lace across international borders throughout Europe. These geometric patterns, with their straightforward visual and fashionable appeal, were also relatively simple to execute, and could be manipulated by women with little experience. ${ }^{23}$ This, then, was an international language that could be used and understood by anyone with basic lacemaking skills, whatever their country of origin within Europe.

Designers such as the Italian engraver Danieli, provided special inspiration with work based on patterns that could be used architecturally, as well as in the fine thread work

\footnotetext{
${ }^{22}$ Kraatz, Lace, History and Fashion, 16.

${ }^{23}$ Ibid.
} 
of laces that were designed to be appreciated at close range. He printed five pattern books between 1610 and 1639, containing delicate engravings and opulent designs.

The patterns were used not only for lace but also for embroidery, furniture, garden design and the decorative arts generally. Formed around a central motif, such as a vase, the lace required the observer to "read" in a particular direction, much like the pages of a printed book. ${ }^{24}$ (See Fig. 4). Lace and embroidery pattern books thus inspired new designs in other art forms, as they replicated prevailing fashions.

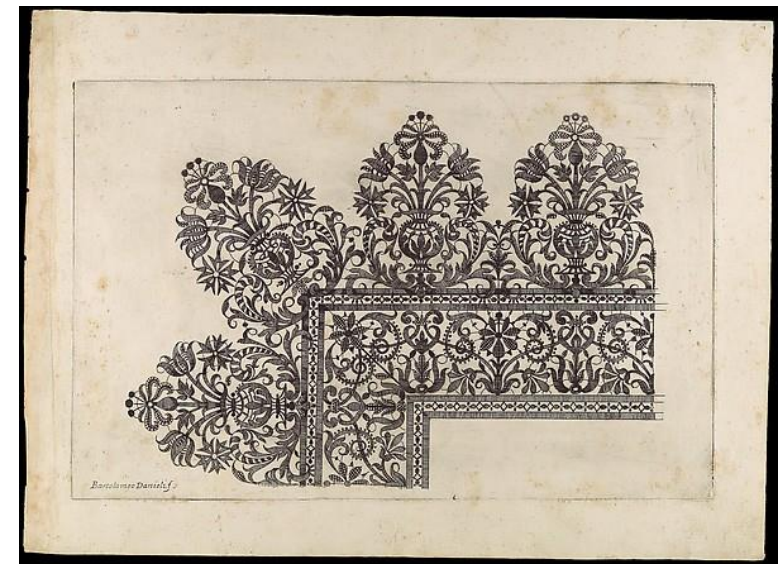

Figure 4.

Bartolomeo Danieli, Design Pattern, 1639, Etching, 34 x 49cm. New York, Metropolitan Museum of Art.

The pattern books were intended for use by aristocratic women, but were also utilised by professional needle lace makers, seamstresses working for the corporation of linen-drapers, nuns and the inmates of hopitaux ${ }^{25}$ and other charitable institutions. ${ }^{26}$

\footnotetext{
${ }^{24}$ Kraatz, Lace, History and Fashion, 37.

${ }^{25}$ These institutions were different to our understanding of hospitals today, which only treat the sick. These were built to house the poor and cared for pilgrims, pregnant women and the infirm.
} 
The pattern books provided a visual language of design and pattern of symbols that needle-workers could use without resorting to a written text. This was particularly relevant when most of the population could not read text. By following a series of diagrams, a complex design could be learnt and fabricated. There were no instructions on how to recreate the pattern, what stitches to use or what colours to add. Printers assumed that the readers of these pattern books already had a basic vocabulary, such as a knowledge of what stitches would work best to achieve the required effect of shading or lines, what type of thread would create the most attractive texture, together with a knowledge of the tools required to make the stitch such as needles and frames. ${ }^{27}$ As is the case when following a knitting pattern, familiarity with the pattern could lead the stitcher to learn a new language or new design terms without having to refer back to the original symbols.

Many different types of laces evolved and most were named after the place of origin of their fabrication. They became identifiable by the techniques and symbolism of the designs included in their manufacture.

\section{Point de Venise}

All point de Venise lace, the most highly sought after lace during the seventeenth century, shared common stylistic features, speaking a baroque language of ritualised embellishment that reflected the codes of courtly behaviours. Embroiderers had improved their techniques and skills in manipulating the fine white flax thread and

\footnotetext{
${ }^{26}$ Kraatz, Lace, History and Fashion, 16.

${ }^{27}$ Maureen Goggin, "Visual Rhetoric in Pens of Steel and Ink of Silk: Challenging the Great Visual/Verbal Divide," in Defining Visual Rhetorics, ed. Charles Hill and Marguerite Helmers (London: Lawrence Erlbaum Associates, 2004), 96.
} 
were now able to produce complex designs. As with filet embroidery, point de Venise reflected the style and preoccupations of other art forms, such as interior design and painting: curvaceous flora, representing exotic leaves and flowers. ${ }^{28}$ (See Fig. 5) Venice had been an important trading centre with the East for many centuries and this prolonged contact with Eastern culture led to designs that referenced exotic flora and fauna such as tulips, carnations, narcissi, different kinds of lily and thistle flowers, and the pomegranate motif, a fruit hitherto unknown in Europe. This complexity along with its prominent high relief curves and scrolls, made point de Venise the most exciting of all laces. The lace produced a "sensual effect of movement," 29 making it the most desirable of all laces in France.

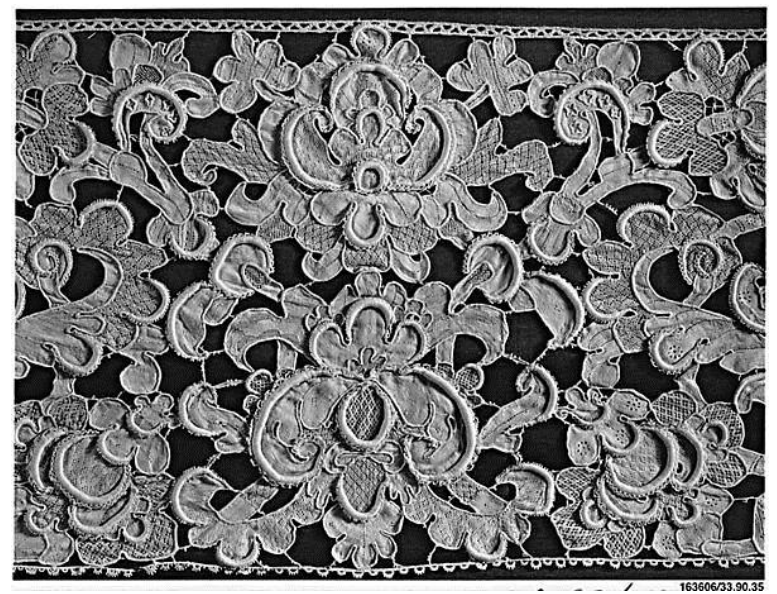

Figure 5.

Point de Venise border of needlelace, 17th century, 306.1 x $20.3 \mathrm{~cm}$. Metropolitan Museum of Art.

\footnotetext{
${ }^{28}$ Santina Levy, Lace, A History (London: Victoria and Albert Museum, 1983), 32.

${ }^{29}$ Kraatz, Lace, History and Fashion, 45.
} 
Gros point de Venise

Gros point de Venise was to lace what Handel's most stately compositions were to music in the middle of the seventeenth century. As a lace it was relatively heavy and opaque. It was intended to be worn flat, in such a way as to display its three dimensional design to full advantage. The light and shade effects of gros point de Venise was not only provided by the presence and absence of actual thread, as in other lace forms, but also by the shadows thrown onto the wearer as a result of the relative height and thickness of the raised cordonnet. ${ }^{30}$ Because the buttonholed filling stitches of the motifs were often tightly worked, these dark shadows mostly fell on the white areas of the lace as well as on any underlying fabrics or skin. ${ }^{31}$ This was particularly effective in the evenings when candlelight was the main source of illumination, as it created intimate plays of light and moving shadow. These dynamic shadows and the way the embroidery was inset with spangles created a theatrical effect, which was important to the language of power and privilege at royal courts where the lace was most often seen. The effect of gros point de Venise was the ultimate expression in thread of the spectacular and ornate Baroque aesthetic and its underlying "vision $d u$ monde."

\footnotetext{
${ }^{30}$ Cordonnet is a core of threads covered with close button-hole stitches, which form the relief of a needle lace. On occasions human hair and horse hair were used as the core.

${ }^{31}$ Elizabeth Walsh, "Gros point de Venise: Lace and its representation 1660-1702" (PhD diss., University of East Anglia, 2009), 41.
} 


\section{Point de France}

Point de France lace, on the other hand, began to gain favour with the aristocracy over the heavier point de Venise, in the late seventeenth century, encouraged by the initiatives and sponsorship of the French lace industry by Jean Baptiste Colbert. French taste at the time favoured a structured and formal ornamentation and the design of the French gros points were arranged vertically, with flowers and pomegranates equally distributed on either side of a central axis, as opposed to the horizontal code of the point de Venise. ${ }^{32}$ This gave the appearance of a mirror effect, an aesthetic perfectly adapted to a court living in the reflective surroundings of Versailles. Many of the designs for Point de France required large areas of fabric and were more suitable for furniture and flounces rather than clothing. Accordingly, the albs of ecclesiastical clothing frequently used large amounts of this white lace and it was worn in extravagant quantities by leading prelates, as seen in the engraving of Bishop Jacques-Benigne Bossuet, by Pierre-Imbert Drevet. (See Fig. 6) It spoke of wealth, power and piety. In time, Point de France came to rival point de Venise. Other laces, too, emerged in the seventeenth and eighteenth centuries and it became possible to identify their origin through the visual codes of their designs, their techniques and material: point de neige, with minute picots that made the fabric appear as if it were dotted with snowflakes, the needle-laces of Alençon, Argentan

\footnotetext{
${ }^{32}$ Kraatz, Lace, History and Fashion, 48.
} 
and Sedan, with their hexagonal mesh, and bobbin lace from Flanders, with its exotic flowers and foliated scrolls. ${ }^{33}$

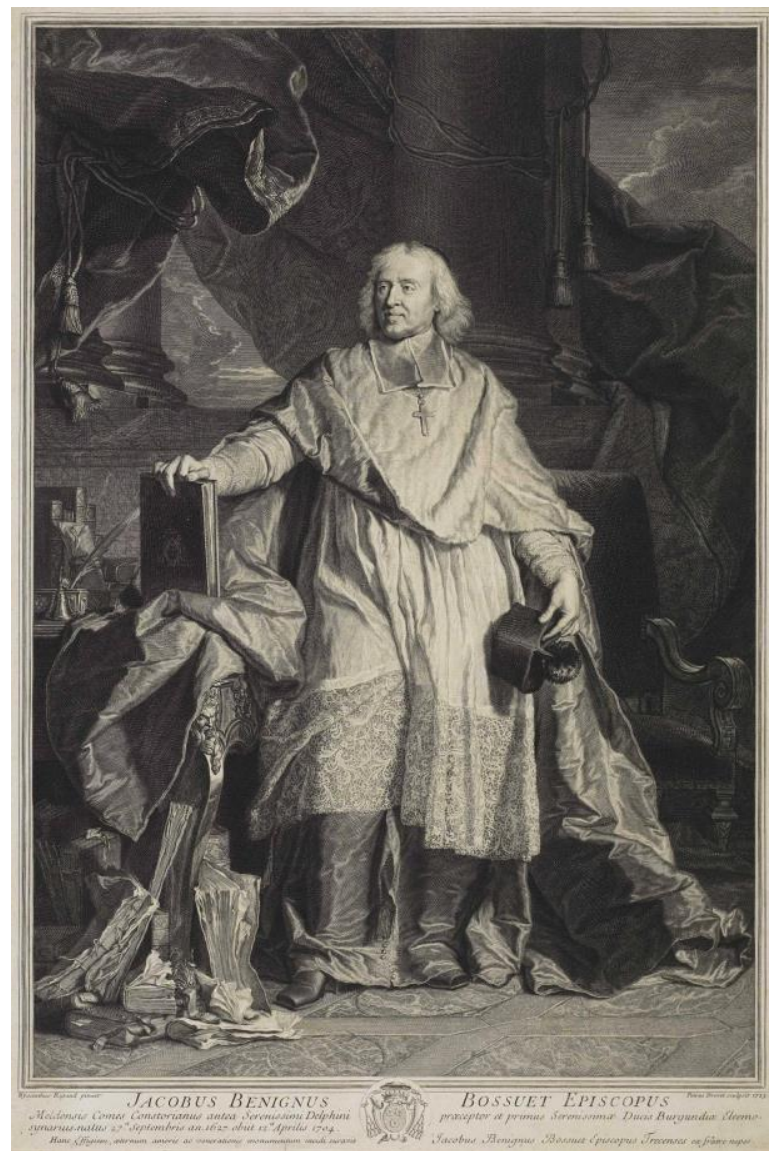

Figure 6.

Pierre-Imbert Drevet, Bishop Jacques-Benigne Bossuet, 1723, engraving, 509 x 307mm, London, The British Museum. (C) Trustees of the British Museum.

The origin of these laces became a marker, easily decoded by aristocrats of wealth and status. Further refinements to this 'message' were derived from an appreciation of the lace's virtuosity, the quality of the materials used and the execution of the design. By choosing fine material and complex designs full of exotic and oriental motifs, the

\footnotetext{
${ }^{33}$ Kraatz, Lace, History and Fashion, 56.
} 
wearer indicated a high level of education and exposure to the world of exploration and discovery, things that exercised a particular fascination in French high society at the time. Some lace included specific symbols commissioned for their personal relevance. A cravat in two sections was made for Louis XIV shortly before his death (See Fig. 7). This design includes many allusions to the King and to military victory. In addition to the trophies of war-drums, standards and weapons, there are two angels

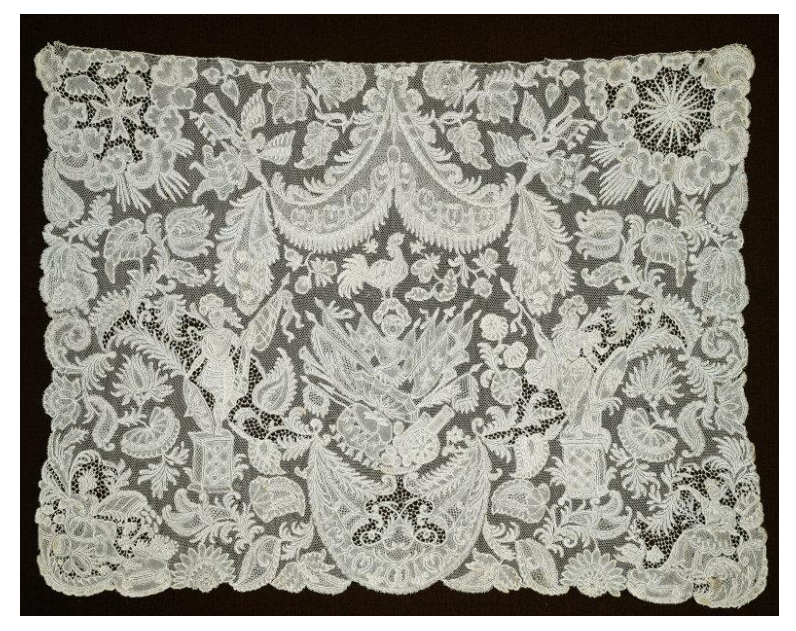

Figure 7.

Cravat End with monogram of Louis XIV, Bobbin lace, point d'Angleterre, Brussels, 1675-1715. Art Institute of Chicago.

blowing the trumpets of fame supporting a dais on which is perched the cockerel of France. The sun, the personal emblem of Louis XIV, appears to smile at the angel on the right out of the clouds and shafts of lightening, symbolizing the return of peace. Finally, in the middle of the border appears the monogram of Louis XIV, the double L. These symbols conveyed a story of Louis XIV that was unique to him. Lace and embroidery demanded attention. It had to be read not just looked at, and understood, to be truly seen, like a text requiring interpretation by a reader before its nuances could be fully appreciated. 
Symbols alluded to the wearer's rank, marital status, ancestry, or specific events in his or her life; coats of arms, motifs such as Louis XIV's sun motif and the fleur-de-lys, the torch of hymen for married ladies, dolphins for royal births. These symbols were closely woven into the rituals and etiquette of society.

\section{Who did the work?}

Aristocratic women stitched embroidery at home. Parker writes, "Embroidery evoked the femininity of the nobility and yet suggested the service and subservience required of the merchants wife." 34 Aristocratic women embroidered in the privacy of their homes. For example, Catherine de Médicis was well known for her love of stitching and Frederico Vinciolo dedicated his pattern book of designs in 1587 to her with a sonnet,

These patterns and designs dedicated to you,

To while away your time and occupy your mind.

In this new enterprise there's much that you can learn.

And finally this craft you'll master in your turn.

The work agreeable, the profit great you'll find. ${ }^{35}$

Several generations later, Louis XIV first wife, Marie Thérèse, his last mistress and second wife, Madame de Maintenon enjoyed this work. Louis XV's wife, Maria Leszczyńska was also a skilled embroiderer, as were her daughters. Royal wives and consorts brought sponsored orphans who showed promise as embroiderers, from the

\footnotetext{
${ }^{34}$ Rozsika Parker, The Subversive Stitch, 63.

${ }^{35}$ Vinciolo, Les singuliers et nouveaux pourtraits, 5.
} 
convents they patronised, to Versailles to live and work. ${ }^{36}$ It was recognised and acknowledged as an acceptable feminine pastime for educated and moral women. Madame de Maintenon believed that education in embroidery was an essential part of a girl's education and it was part of the curriculum at her school for poor noble girls that she founded at Saint-Cyr.

In Rozsika Parker's foreword to her book, The Subversive Stitch she writes, "To know the history of embroidery is to know the history of women". ${ }^{37}$ But this indeed is only part of the story. There is also a narrative to tell of men's association with the art of embroidery. History tell us that the embroiderers to French kings were men, even while acknowledging that there were some instances where merchants were attributed the skill of embroiderers when in fact they were only the vehicle of the commission and the actual work may have been carried out by women. ${ }^{38}$ The following definition to be found in L'Encyclopédie printed in 1771, defines the embroiderer as:

l'ouvrier qui ornes les étoffes d'ouvrages de broderie.V. BRODERIE. Les brodeurs, à Paris, font communauté. L'on ne comprend sous le nom de Brodeurs, que les ouvriers qui travaillent sur des étoffes. Les broderies en linge se sont par des femmes, qui ne sont ni du corps des Brodeurs, ni d'aucun autre. ${ }^{39}$

\footnotetext{
${ }^{36}$ Palmer White, Haute couture Embroidery: the Art of Lesage Paris: Vendome Press, 1998), 21.

${ }^{37}$ Rozsika Parker, The Subversive Stitch, (London: I.B.Tauris \& Co Ltd, 2010) ix.

${ }^{38}$ Ibid., 45. This compares to contemporary practice where haute couture designs of embroidery are attributed to the designer not the stitcher.

${ }^{39}$ Diderot, Denis, Jean Le Rond Alembert and Pierre Mouchon, Encyclopédie: ou, Dictionnaire raisonné des sciences, des arts et des métiers, 1751-1772. Geneve: Pellet, 1777.s.v. Brodeur.
} 
This entry advises us that the needlework of the linen of the household was undertaken by women, and not in the embroidery workshops of the guilds. It was appropriate for women to undertake these chores but not to work in the more prestigious ateliers. It is known that women did work in these ateliers but it would appear that these workers were working outside of the regulations imposed by the guilds.

Louis XIV had many embroiderers in his household and Lefébure mentions Jean le Boyteu, Jacques Remy, Jean Henry and his son Etienne Henry, all hereditary grooms of the chamber. On June $2^{\text {nd }}, 1679$, Jacques Remy received a payment of 4000 livres “en acompte d'un brocart en broderie qu'il faisait pour le roi." 40 This was a large sum of money, indicating the importance and esteem in which Louis XIV held embroidery. The king also lavished large sums on furnishing embroideries, which were undertaken at the Gobelins workshops, set up by Colbert, Louis' Minister of Finance.

There were eight licensed embroiders in 1770, who did not come under the jurisdiction of the Provost of Paris, but who were Brodeurs du Roi suivant la Cour. In particular there were two embroiderers who specifically worked on embroideries for the Crown, Brodeurs du Roi. These embroiderers were all male. ${ }^{41}$ Under the ancien régime, embroidery was a profession, with workers grouped into guilds, or corporations. The Royal embroiderers were the only exception to this.

\footnotetext{
${ }^{40}$ Ernest Lefébure, Broderie et Dentelles, (Paris: 1908), 142.

${ }^{41}$ Saint-Aubin, C.G. de, L'art du brodeur (Paris: De L'Imprimerie de L.F. Delatour, 1770), 19.
}

When very busy, for example with a festivity or royal wedding, the royal embroiderers could take workers from the Maîtres. 


\section{Embroidery Guilds}

The guild of brodeurs-découpeurs-égratigneurs-chasubliers de Paris had been noted, as early as the thirteenth century by Etienne Boileau, Provost of Paris. This guild was confined to a male membership and was still in existence during the reign of Louis XIV, when guild structures were an integral part of French industry from large cities to small towns. The last governing statute of 1719 details the requirements of membership of the Guild which was designed to maintain the quality of embroidery produced and to protect the employment of its members and their families. ${ }^{42}$ Examination of this document gives an insight into the working environment of the embroiderers of that time. These statutes were changed according to fashion and circumstances. ${ }^{43}$ They directed who could undertake the embroidery, the materials to be used and the quality and nature of the work itself. The head of the embroiderer's workplace was the master embroiderer himself, l'Entrepeneur, who was also, by virtue of his longstanding experience and quality of work, the Maître. Practices dictated by the governing statute included strict rules. For example, a Maître could only be assisted by his sons or daughters, while other male workers could be used when needed, provided they were housed outside of the Maître's licenced locality. It was forbidden to mix pure gold or silver with fake gold or silver in the same

\footnotetext{
${ }^{42}$ René Lespinasse, ed., Les Métiers et Corporations de la ville de Paris XIV-XVIIIe Siècle: Histoire Générale de Paris, 1886-97), 2: 165.

The publication of the embroiderers rules in 1719 were taken from the "Statuts des BrodeursChasubliers en 46 Articles," which were confirmed by documents from King Louis XIV on August 14, 1704.

${ }^{43}$ Saint-Aubin, L'Art du Brodeur, 19.
} 
embroidery indicating that there was an industry of false reproduction existing at the same time. ${ }^{44}$ The work was to be produced mainly in the home of the Maitre, indicating a patriarchal system of production. Confirming the patriarchal structure of the guilds was their strong moral dimension that included encouraging their members to participate in religious devotion and charitable relief. ${ }^{45}$ Through their monopoly on production, the guilds allied public piety with power, determining methods and volume of production, and overseeing the quality of the goods produced. Unlike those who supported freer markets, the guilds insisted on long apprenticeships and tight regulation of every aspect of production. Following apprenticeship, a worker would have to work as a compagnon, or journeyman for a period of three years before he could apply to be a Maître. Many guilds also required members to be born in the same city in which the guild was located. In this respect, the guilds were sometimes as parochial as they were patriarchal.

The cultural association of women with certain tasks related to the use of a needle made it acceptable for Maîtres to overcome the legal constraints of the time, and to use female embroiderers in their workshops - even though this was against their own regulations. ${ }^{46}$ Farnault points out there was also an embroidery workshop at Saint Joseph's Convent in Paris, which obviously was not operating as a guild structure, but was tolerated. ${ }^{47}$

\footnotetext{
${ }^{44}$ Ibid.

${ }^{45}$ Michael Fitzsimmons, From Artisan to Worker, (New York, Cambridge University Press, 2010), 9.

${ }^{46}$ Clare Haru Crowston, Fabricating Women (London: Duke University Press, 2001), 183.

${ }^{47}$ Hélène Farnault, Haute Couture Ateliers, 97.
} 
Female embroiderers thus worked in less illustrious surroundings, and with less recognition than their male counterparts. But needlework was considered appropriate to their sex, as long as they worked discreetly and preferably under male guidance.

In the late seventeenth century there were a limited number of female guilds that operated as a professional trade, for example the seamstress' guild was only created in $1675 .^{48}$ Within this guild, seamstresses were able to become masters in their own right and to operate their own guild, undertaking women's work for women's bodies, which was deemed appropriate, frustrating the tailors whose domain the seamstresses took over. The embroidery guild however, did not accept women until 1778, when 12 women joined the guild following the revocation of Turgot's edict, which had dissolved the guild structures in $1776 .^{49}$

While Colbert allowed the seamstresses to form their own guild in 1675 , neither female embroidery guilds nor female lacemaking guilds were allowed to form. And yet women were clearly evident in the workshops of the Maitre, as evidenced in the illustrations in Diderot's L'Encyclopédie and Saint-Aubin's book, L'Art du Brodeur. (See Fig. 8). The engravings show men doing the more physical work of stretching fabric onto frames while women are shown undertaking the stitching.

\footnotetext{
${ }^{48}$ Crowston, Fabricating Women, 182. There was an expectation that women would undertake work that was appropriate to their sex, which included needlework but Crowston has identified that this was not a new notion but was one that was "an inheritance from classical and Christian traditions."

${ }^{49}$ Ibid., 211.
} 


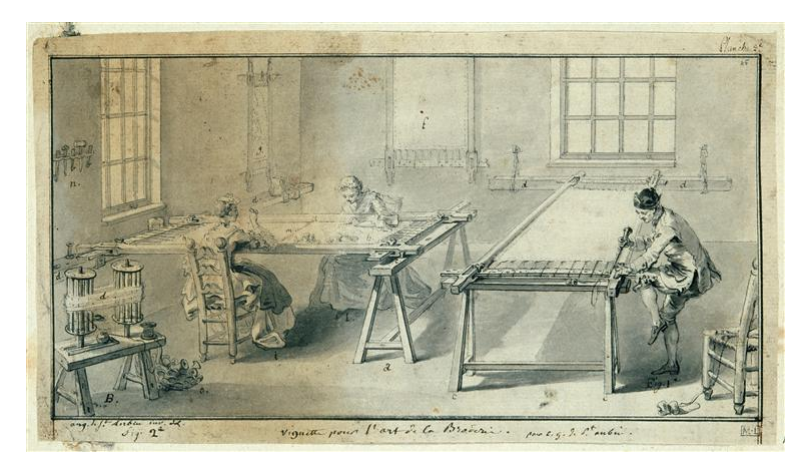

Figure 8 .

Saint-Aubin, Augustin de, Un atelier de broderie, 18th century, black and brown ink drawing, 0.123 x $0.223 \mathrm{~m}$. Paris, Musée du Louvre, RMN.

Crowston's research has shown that while apprenticeships were not available to female embroiderers, vocational training in charitable schools was clearly evident. These free schools, established in most Parisian parishes in the late seventeenth century, were segregated by sex and children entered at the age of eight years and stayed for two years. The instruction for boys was related to arithmetic and writing whereas a significant part of the girls training was dedicated to needlework. Surviving documents indicate that these skills were seen to "serve vocational, moral or social purposes. ${ }^{50}$ Following this education, young women could progress to a female religious community, whose aim was to give them skills that would enable them to earn their own living, as well as ensuring that their "religious and moral indoctrination" received at the elementary school was not lost in the time between childhood and marriage. ${ }^{51}$ The Filles de Saint-Agnès, created in 1678 in Saint Eustache parish, provided training in linen work, embroidery, lacemaking and

\footnotetext{
${ }^{50}$ Clare Crowston, "Women, Gender and Guilds in Early Modern Europe," 16. http://www.iisg.nl/hpw/papers/guilds-crowston.pdf (accessed January 16, 2015).

${ }^{51}$ Ibid., 17.
} 
tapestry making. ${ }^{52}$ In fact this was a form of apprenticeship although not officially recognised. This attitude to female education was to persist through to the twentieth century. Interestingly, Crowston has discovered that this training was supported by Colbert himself, who, on one hand was responsible for requiring all trades to form a guild and on the other hand supported the sisters in obtaining official letters in 1682 and left the community 10,000 livres in his will, knowing that the women would be working illegally following completion of their training. ${ }^{53}$ The alternative explanation is that these women were embroidering "en linge" as described in the entry for brodeur in L'Encycopédie, previously mentioned.

This acceptance that women could work illegally was sometimes tested in times of increasing competition, with less work for each atelier. The embroidery guild filled an important role in the fabric of urban life, regulating behaviour and overseeing indiscretions. During an era when law enforcement was not well established, the guilds played a significant role in supplementing the police and overseeing their own restrictions with a panel of elected jurés. In April 1692, the Parisian embroiderers' guild successfully prosecuted a group of its own masters for having hired female workers (fausses-ouvrières). Masters were instructed to conform to guild rules and to hire only qualified male workers. Despite the fact that embroidery was strongly associated with femininity, women, as Crowston observes, were not yet entitled to legally exercise their skills for economic gain. ${ }^{54}$

\footnotetext{
52 Ibid.

${ }^{53}$ Ibid.

${ }^{54}$ Crowston, Fabricating Women, 183.
} 
In 1770 Saint-Aubin, designer to the King and son of a master embroiderer, published his book l'Art $d u$ Brodeur, a major key to the practice and techniques of embroidery. As seen in Figure 8, he describes the positions of women embroiderers in relation to whether they are left handed brodeuses, called gauchères, or right handed brodeuses, sitting opposite, the droitières. The work also clarifies that in 1770, embroidery was the most well paid profession for women, around 25 sols for one day or four francs per ounce for passé, a form of reversible embroidery. The day started at 6.00a.m. and finished at 8.00p.m., but extra pay was given for longer hours or for work that was finer. A lot of the work undertaken was with gold thread, (the province of men prior to the eighteenth century), and this was weighed and noted before a worker took the project home. ${ }^{55}$ The embroiderers were supplied with some materials and tools, such as candlesticks and bobbins, but they were expected to provide their own needles, thimbles and scissors. ${ }^{56}$

Saint-Aubin also provides insight into design practice from centuries prior to his own. From the sixteenth century for example, many of the designs commissioned from the artists of Lyon used for embroidery but also for sculpture, painting, tapestry design, metalwork and gildings. The designs were circulated via collections of engravings. ${ }^{57}$ Saint-Aubin implies that the expertise and initiative of the embroiderer could influence the techniques and final appearance of the embroidery project, endorsing the notion that the embroiderer could influence the message imparted through the physicality of the piece, and by the threads and stitches used. The best embroiderers

\footnotetext{
${ }^{55}$ Saint-Aubin, L'Art du Brodeur, 25.

${ }^{56}$ Ibid.

${ }^{57}$ Ibid.
} 
were known to have their own style and were thus engaged in the articulation and expression of the language of power.

During the eighteenth century, guilds were threatened by outside markets and infighting. Accordingly, in 1776, Turgot published six edicts, one of which included disestablishment of the guilds. Unlike Colbert, Turgot believed in deregulation and the freedom for all people to be able to work, including women. This was extremely liberal. After a few months the guilds were allowed to reorganise, however, as not everyone agreed with Turgot's vision for a society of equal opportunity. His chief opponent was Séguier, the Attorney-General, who believed the dissolution of the guilds would undermine the social structure of France and hence the monarchy, which was also Colbert's greatest fear. Séguier therefore allowed for the resurrection of the guilds. Both men agreed, however, that women needed to be able to work in areas that were intrinsically female trades, including embroidery. They also agreed finally that guilds should be opened to women. Concerned with rising female poverty, and the likelihood that unemployed women would turn to prostitution, "Both sides now viewed women's work as inextricably connected to female sexual morality". ${ }^{58}$ Two different economic models thus co-existed, a restricted guild structure and a more inclusive, less regulated labour market.

${ }^{58}$ Crowston, Fabricating Women, 210. 


\section{Lace makers}

Delpierre lists the many ouvrières who worked on needle-laces. For example in the making of Alençon lace, one of the most highly valued needle laces, the following workers engaged in different stages of the production process:

- La piqueuse made holes in the parchment

- La traçeuse, placed the tracing threads along the contours of the drawing.

- La brideuse and la réseleuse made the brides or the ground,

- La fondeuse made the flower background using buttonhole stitch,

- Les remplisseuses, added detail to the flowers profile,

- $\quad$ La modeuses made the openwork

- La brodeuses executed the relief which marked out each flower,

- L'ébouteuse and the régaleuses perfected the lace after the vellum was removed.

The lace was made in small pieces and then assembled and fashioned onto the article, or stitched together to form larger pieces. ${ }^{59}$ Needle lace was a very labour intensive undertaking.

This was in contrast to bobbin lace that could be quickly fabricated by one worker, using a cylinder with the design formed in holes on the surface. Pins were placed in each hole to guide the thread as the work progressed. In this case the work was

\footnotetext{
${ }^{59}$ Madeleine Delpierre, Dentelles et Broderies dans la Mode Francaise du XVIe au XXe siècle (Paris: Musée de la Mode et du Costume de la Ville de Paris: 1964), Chapter 4.
} 
completed in one piece or was appliquéd with a needle onto a tulle or background réseau, or network. Because the equipment used was small and mobile, it was difficult for the original male passementiers to maintain control over production, and this made it possible for women to undertake the production of bobbin lace without reference to the structures of the guild. Between 1690 and 1725, after a period during which the corporations were strengthened, Jacques Savary des Bruslons listed 126 guilds for different crafts, but no local guilds of lace makers were identified ${ }^{60}$ Instead there were families of specialists who worked with local lace makers to develop and concentrate production. At no time did women lace-makers form their own guild/corporation, despite the economic importance of their production, which in time rivalled that of embroidery. ${ }^{61}$

Originally, for both bobbin lace and needle lace, lace makers worked for themselves, with drawings given to them by managers. The designs of the drawings were created by the great artists like Jean Cousin in the sixteenth century, Le Brun and Bérain in the seventeenth century and reflected prevailing tastes in fashion. By the nineteenth century most great lace makers were creating their own designs or using a drawing studio, while others simply used designs from Paris.

Lace makers were essentially intermediaries between the small rural family producers and the Parisian creditors and clients who provided the raw material or sold the lace

\footnotetext{
${ }^{60}$ Jacques Savary des Bruslons, Dictionnaire universel de commerce, 3 vols (Paris: Veuve Estienne, 1741), cited in Crowston, Fabricating Women, 75.

${ }^{61}$ Clare Haru Crowston, "Women, Gender and Guilds in Early Modern Europe" (presented at the conference Return of the Guilds, Utrecht University, Utrecht, 5-7 ${ }^{\text {th }}$ October, 2006), 18.
} 
produced in the Ile-de-France throughout France and Europe. ${ }^{62}$ The trade brought together wholesalers and retailers in the rue Saint Denis, where a wide range of goods, linen, braid, ribbons buttons and lingerie was sold. These were merchants, mercers, linen merchants, and merchant ribbon-weavers. In the scattered workshops from Les Halles to the faubourgs, modistes, ribbon weavers and braiders employed lacemakers. Large merchants provided the raw materials for a largely female population of workers through the intermediary of masters or mistresses who put out the work. ${ }^{63}$ Ultimately sales depended on the consumer's choice, which in the case of courtiers was dictated by the king himself. But working conditions were not always good. Bobbin lace made in Valenciennes, with the fine flax thread of Flanders, was highly valued. Lowes writes, "This lace was made in dark damp cellars, the moist atmosphere being necessary to prevent the tiny thread breaking. The lace workers became nearly blind, and quite useless before they reached the age of thirty" ${ }^{64}$

\section{Colbert's Sponsorship of the Lace Industry}

The imported laces made in Venice and Flanders were initially of a much higher quality than French lace and this was a matter of concern for the Minister of Finance and Trade to Louis XIV, Jean-Baptiste Colbert. Maybe as a result of it not being overseen by a guild structure as was the case for embroidery, lace production in France was scattered geographically, quality was variable and there was no real

\footnotetext{
${ }^{62}$ Daniel Roche, La culture des apparences, trans. Jean Birrell (Paris: Libraire Arthème Fayard, 1989), 273.

${ }^{63}$ Ibid., 314.

${ }^{64}$ Project Gutenberg Ebook, Chats on Old Lace and Needlework, (2008), http://www.gutenberg.org/files/26120/26120-h/26120-h.htm. 90. (accessed 24 November, 2014).
} 
commercial structure to exploit its increasingly obvious value as a commodity. Colbert, as Minister of Finance, was especially keen to improve the quality of lace produced in France in order to stop the flow of monies out of the country, which was paying for imported laces from neighbouring European countries. He was also active in promoting sumptuary laws, which I will discuss in Chapter Three. He persuaded the king to establish lace making manufactories in several towns, and planned to upskill workers who could manufacture lace to a standard that would make it as desirable as the expensive points de Venise that was a favourite amongst the aristocracy. The following proclamation was published $5^{\text {th }}$ August 1665:

in the towns of Quesnoy, Arras, Rheims, Sedan, Château-Thierry, Loudun Alençon, Aurillac, factories for all kinds of thread work made either with the needle or on the cushion, in the manner of laces which are made in Venice and Genoa....and other foreign countries, and which will be called points de France. ${ }^{65}$

To achieve his goal Colbert even attempted to entice Venetian lace workers to France to teach their skills to local workers, offering them French nationality. He was not entirely successful, since only a few accepted his invitation. He was able to extract valuable information about the manufacture of the lace, however, from the then French ambassador in Venice, Cardinal Bonzy, in an act of industrial espionage. Thanks to these strategies, the quality of point de France eventually became so good that it became difficult to differentiate it from its Venetian competitor.

Production was limited, however, since some local French communities remained resistant to the manufactories even while Colbert was actively recruiting young

\footnotetext{
${ }^{65}$ https://www.cs.arizona.edu/patterns/weaving/articles/nb30_pnt.pdf. (accessed March, 2015).
} 
females to train in the lace industry. He enforced designs from the King's designers and painters and no one outside the Royal manufactories was allowed to copy them. This monopoly provoked riots in Alençon, fraud and subterfuge as even the local convents continued to work independently of Colbert's sponsorship. ${ }^{66}$ Subsidies were initially granted for 9 years and this helped increase quality and production dramatically. French lace developed a style of its own which made it recognisable as being distinct from, yet equal in quality to point de Venise. In July 1666, Louis XIV bought point de France worth 18,491 livres. In comparison the annual salary of Charles le Brun was 11,200 livres. ${ }^{67}$ France did not excel so well in the production of bobbin lace, until the mid-eighteenth century when the lace manufacture in Valenciennes was able to compete with the imported laces of Flanders.

In the early eighteenth century, the lace was gossamer fine, often requiring a magnifying glass to reveal the splendour of its workmanship and design. ${ }^{68}$ It was also worn in vast quantities, which required thousands of lace makers. These numbers decreased in the 1770s and steadily dwindled during the French Revolution from 1789. The democratization of lace contributed more than any other factor to lace's dramatic drop in value: it was no longer the symbol of aristocratic prestige. ${ }^{69}$

In the second-half of the eighteenth century, major political and economic changes would become powerful influences on all sectors of society. The ideas associated with

\footnotetext{
${ }^{66}$ Kraatz, Lace, History and Fashion, 48.

${ }^{67}$ Ibid., 50.

${ }^{68}$ Johanna B. Moyer,"Sumptuary law in ancien régime France, 1229-1806." (PhD diss., Syraceuse University, 1997).

${ }^{69}$ Anne Ratzki-Kraatz, "The Elegant Art of Dress," in An Elegant Art: Fashion and Fantasy in the Eighteenth Century, ed. Phil Freshman (New York, Harry N. Abrams, Inc., 1983), 109.
} 
the period of the Enlightenment, and its social and scientific revolution, were represented by the writings of Diderot, Rousseau and D'Alembert in L'Encylopédie. ${ }^{70}$ This massive encyclopaedia includes many entries regarding lace; its origins, manufacture and importance, and the authors give detailed insights into the material culture of lace at the time. The following entry for the definition of lace, confirms its ongoing merit artistically and as a commodity, despite fluctuating tastes and markets.

Les dentelles font des ornemes très-beaux et très-precieux; celles enfil au linge des homes et des femmes, celles en or et en argent, aux habits et aux meubles. Elles font partie du commerce des Merciers et de Lingeres. Il y a des garnitures de femmes qui vont au-de là de deux mille écus. ${ }^{71}$

Metal laces and black laces were produced in the north of Paris in Oise, and Lyons was known for its gold and silver laces. ${ }^{72}$ The materials most commonly used by the professional embroiderers at court in the eighteenth century were silk, wool chenille, gold and silver thread. These were the basic syntax of the professional embroiderer's craft. Spangles and jewels were then positioned on the fabric to maximise the reflections of the candlelight. ${ }^{73}$ This added to the drama of court dress, which was totally subservient to the language of power utilised by the king himself. White-work embroidery with white linen thread on net or muslin was also popular in the eighteenth century, although the demand decreased significantly during the period of the Revolution. $^{74}$

\footnotetext{
${ }^{70}$ Denis Diderot, Jean Le Rond Alembert, and Alain Pons, Encyclopédie: Ou, Dictionnaire Raisonné Des Sciences, Des Arts Et Des Métiers, 1751-1772 (Paris ).

${ }^{71}$ Ibid., s.v. "Dentelles."

${ }^{72}$ Kratz, Dentelles, 38.

73 Aileen Ribeiro, Dress in the Eighteenth Century 1715-1789, (B.T. Batsford Ltd, 1984),73.

${ }^{74}$ Hélène Farnault, Haute Couture Ateliers, 97. It was later revived by Empress Josephine.
} 


\section{New Techniques and Industrialization.}

It was during the Second Empire that mechanisation began. This was to have a disastrous effect on hand-made lace and embroidery. English looms for making tulle were smuggled into France as early as 1802. First set up in Calais, they spread throughout northern France. Once the tulle had been manufactured, it was then embroidered. Jacquard weaving looms soon followed, and these could produce bobbin silk, linen and cotton. Finally in 1880, the invention of the Schiffli machine made it possible to mechanically produce needlepoint lace of the Alençon and Venetian type. ${ }^{75}$ Sewing machines were used in France from the 1830s and mechanisation produced laces at a lower price with a high visual intensity. The laces were now chosen by women from two-dimensional drawings, rather than through direct tactile appreciation of the fabric beforehand. During the 1840s it was important that newly acquired wealth and position in particular were flamboyantly obvious. It mattered not that at close hand, hand-made laces were more beautiful and intricate while machine laces, examined closely, lost their attractiveness. It was the instant visual impact that was more important. ${ }^{76}$ As time progressed the production of hand produced lace in France became uneconomic. Hand-made lace was soon relegated to a handcraft, undertaken by women with time on their hands and associated with domesticity and femininity, following the domestication of women's role in society, as promoted by Rousseau, to be discussed in Chapter four. This sense of a superfluous wealth of time was all that remained of the once splendid and decadent idleness of courtiers.

\footnotetext{
75 de Bonneville, The Book of Fine Linen, 179.

${ }^{76}$ Pat Earnshaw, Lace in Fashion, (London: Batsford, 1985), 85.
} 
In 1865, Louis Ferry-Bonnechaux developed a new technique for attaching sequins, beads and semi-precious stones. Called the Lunéville embroidery or tambour beading, it used a small crochet hook to attach the beading to the base fabric, which was stretched over a frame. ${ }^{77}$ This was a revolution for hand embroidery. The work could be done faster, and hence at a reduced cost. It was worked on the reverse side of the fabric. The maintenueses who used traditional methods with a needle looked down on the lunévilleuses. ${ }^{78}$ Rarely did a piece employ both techniques. The hook technique was mostly used for the immense amount of beading and sequin work that was to become popular on the dresses of the Années Folles and the evening gowns of haute couture.

\footnotetext{
${ }^{77}$ Ibid.

${ }^{78}$ White, Haute couture Embroidery: the Art of Lesage, 43.
} 


\section{Chapter Three: The Language of Power}

\section{Royal Courts}

While lace and embroidery had been used in royal courts previously, Louis XIV was to exploit both material as signifiers of power and status, and to confirm his own position as the 'absolute' monarch. When Louis XIV was 13 years old, he began to take up his responsibilities under the guidance of Cardinal Mazarin. Faced with the ongoing attempts of la Fronde, a series of civil wars, to reduce the powers of the monarchy, Cardinal Mazarin used the tool of triumphant display to promote the king's cause. In 1651 there was a parade through Paris, described in great detail by Madame de Motteville. ${ }^{79}$ Louis was clothed in heavy gold embroidery, while his horse was covered with a caparison embroidered with fleur-de-lys and the crosses of the Holy Ghost, the order of the Saint Esprit, an order of chivalry under the French monarchy. He was preceded by: the Grand Equerry of France in doublet and hose of gold and silver cloth, his horse covered with crimson velvet embroidered with gold; six heralds with velvet tabards embroidered with fleur de lys, the Swiss Guard with gold cords and plumes; the King's Troop of Light Horse with coats of gold and silver cloth, and four trumpeters in blue velvet laced with gold and silver. The Queens' Regent's Troop was led by a lieutenant in a coat embroidered with gold and silver, accompanied by four trumpeters in black velvet trimmed with silver lace. La Fronde was overcome by 1653 and Louis, unsettled by the experience of constant revolt and

\footnotetext{
${ }^{79}$ Françoise Bertaud, Madame de Motteville, Memoires, trs. K.Prescott Wormeley, 1902, vol. 1, pp105-175; vol. III, p44. Cited in Louis XIV and Versailles Diana de Marly, Louis XIV and Versailles. Costumes and Civilization, (New York: Holmes and Meier, 1987), 18.
} 
conflict, became determined not to allow the nobility to undermine the monarchy again. Embroidery production and quality was at its apogee and was thus a fitting ornament for the display of royal power. Louis XIV would come to exploit its potential more fully in the years ahead.

The use of embroidery to accentuate Louis XIV's position of power was evident in his coronation at Rheims on 7 June 1654. Wearing a mantle of violet velvet embroidered with golden fleur-de-lys and matching embroidered shoes he presented an image of royal grandeur and wealth. This image enforced the perception of power. He answered to no one but God, and as an absolute monarch he used his power to dictate what people could and could not do, including the details of their dress. $\mathrm{He}$ used both lace and embroidery as fashion standards for what he expected to be worn at court. His vision was to have the most opulent and luxurious court in Europe, to display his wealth, power and appreciation of the arts, to everyone within his orbit.

The difference between his own court and that of neighbouring countries was highlighted at the meeting with the Spanish court in 1660, on the Island of Pheasants. The Spanish court seemed drab and plain in comparison to Louis XIV's sumptuously dressed courtiers, whose apparel was covered with lace, embroidery and ribbons. ${ }^{80}$ Louis XIV far outshone his future father in law, Philip IV, who was dressed in a sombre grey coat embroidered with silver while his courtiers wore mainly black. Louis XIV on the other hand wore a satin and silk coat, heavily embroidered with glittering gold thread. The marriage of Louis XIV to the daughter of the King of Spain, Maria Teresa in June 1660, was destined to unite the two warring nations, but

\footnotetext{
${ }^{80}$ Diana de Marly, Louis XIV and Versailles, 21.
} 
the difference between the dress of each court could not have been more marked. This was not an equal partnership. Louis XIV's love of such clothes led him to be called le marquis de filigrane, after the filigranes, or metal threads dipped in gold or silver, which embellished his clothes. ${ }^{81}$ Represented in a painting by Jacques Laumosnier, the meeting with the Spanish court confirmed Louis' place in Europe as a fashion leader. (See Fig. 9).

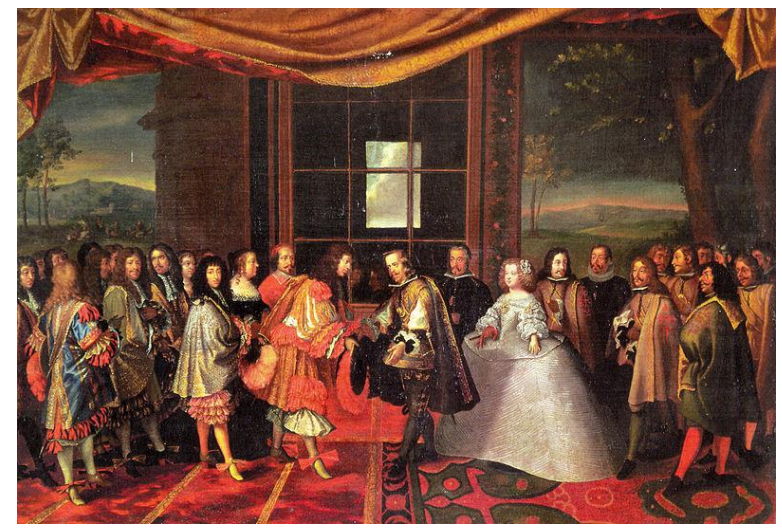

Figure 9.

Jacques Laumosnier, Entrevue de Louis XIV de France et de Philippe IV d'Espagne dans l'île des Faisans en 1659, oil on canvas, 17th century, $89.1 \times 130 \mathrm{~cm}$. Mans, Musée de Tessé.

The many observers of court life wrote detailed letters describing the intricate details of lace, and embroidery that characterized clothing, emphasising its importance as vehicle of political and moral meaning. For example, Madame de Motteville wrote on her observations of the King's return to Paris with his new wife that he looked,

Like the men whom the poets represent to us as transformed into gods. His coat was embroidered with gold and silver, as fine as it should be, given

\footnotetext{
${ }^{81}$ Philip Mansel, Dressed to Rule, Royal and Court costume from Louis XIV to Elizabeth II (Connecticut:, Yale University Press, 2005), 111.
} 
the dignity of the person wearing it...the grandeur which he showed in his person made him admired by all. ${ }^{82}$

The reference to embroidery and lace over and above any other sartorial element highlights the importance of these parures in the visual language of power and status. The sun was often used by Louis XIV as a motif in the embroideries and laces he commissioned. It was a symbol associated with him throughout his reign and originated from his love of ballet. Court ballets had been a favourite of his father, Louis XIII and his mother, Queen Anne of Austria. It was during these early ballets at the beginning of his reign that Louis danced as the deity Apollo and subsequently became known as the "Sun King". Seen as a symbol of power and the giver of life, the sun can be outshone by no one. While enforcing extravagant court dress, Louis preferred the magnificence of others to enhance, and not compete, with own, emphasising his position as the brightest, most powerful star.

The king promoted his image of the sun as a symbol through livery embroideries and the use of colours of the sun in his dress. Locatelli, a visiting Italian priest, describes seeing Louis inspecting his army in 1665 , wearing a flame coloured hat, with his hair held back by two big flame coloured ribbons. He wore a cravat of Venetian lace over a gold collar, and a coat of clear blue mohair so covered with gold and silver it was hardly visible beneath. The coat was unbuttoned to display a vest of brocade and gold in the Polish style, fastened with large golden galloons, and decked with large diamonds. A sash with diamonds, flame coloured garters covered in gold embroidery. The spurs were in violet steel, enamelled, and fastened on with gold buckles encrusted

\footnotetext{
${ }^{82}$ Françoise Bertaud, Madame de Motteville, Mémoires, vol. IV, 225-6, cited in Mansell, Dressed to Rule, 1.
} 
with diamonds. The sun King literally sparkled and gleamed like a celestial body, centre of all light and energy. ${ }^{83}$

When his position of power and magnificence was threatened, he was quick to act. Having encouraged his Superintendent of Finances, Nicolas Fouquet to build a splendid mansion at Vaux-le-Vicomte, he was so astounded by the magnificence of the palace and grounds that he became extremely jealous. After attending the opening party in 1661, Louis XIV had Fouquet arrested for seemingly siphoning off monies, and the contents of the chateau were immediately requisitioned. The king then decided to build a palace that would outshine that of Fouquet, and that would secure Louis' place in Europe as second to none. Building work began at Versailles, the site of his father's hunting lodge, much to the consternation of Colbert, who was conscious of the likely expenditure that such a project would entail.

Versailles was to become the central stage for Louis XIV's reign. Its position outside of Paris suited his desire to control the activities of his nobles in a confined space, and so he moved his court to Versailles in 1682 . The château, combined with the opulent dress of those who inhabited it, became renowned throughout Europe. Louis XIV insisted on a constant display of riches, and the heavily embellished clothing of his courtiers was an important part of this sartorial etiquette. Reynolds writes,

In moving the centre of the court from Paris to Versailles he cultivated an artificial society in which the courtiers, removed from the diversions of the city with little to do other than gamble and gossip, attempted to outdo each

\footnotetext{
${ }^{83}$ S. Locatelli, Voyage en France, (Paris: Vautier, 1905), 39.
} 
other in their search for novel and ostentatiously expensive fashions that would suitably reflect the grandeur of the king and draw his attention. ${ }^{84}$

The dress at court was thus a means of demonstrating both the privileges of the nobility and its dependence on, and close links, to the monarch. ${ }^{85}$

\section{Sumptuary Laws}

Sumptuary laws have been enacted since the medieval period. They were anti-luxury laws, proclaimed by monarchs, which attempted to change the behaviour of certain groups of society and almost always concerned vestimentary materials. By forbidding excessive expenditure and luxury, the wearing of certain types of clothing, particularly those heavily embroidered with gold and silver, was curtailed.

Previously, Louis XIII had issued edicts in 1629 and 1633, attempting to regulate dress codes:

Superfluity of dress that prohibited anyone but princes and the nobility from wearing gold or caps, shirts, collars and cuffs embroidered with metallic threads or lace, prohibiting all other ornament on collars, sleeves and other linens, except those passementeries, cut stitches and laces manufactured in this kingdom not exceeding a value greater than 3 livres per aune. ${ }^{86}$

\footnotetext{
${ }^{84}$ Reynolds, Anna. In Fine Style. London: Royal Collection Trust, 2013, 211.

${ }^{85}$ Gabriele Menteges. http://www.ieg-ego.eu/en/threads/models-and-stereotypes/the-spanishcentury/gabriele-mentges-european-fashion-1450-1950.

${ }^{86}$ Isambert and Taillander, Recueil général des anciennes lois françaises: depuis l'an 420 jusqu'à la révolution de 1789, vol. XVI (Paris: Belin-Leprieur, 1829), 264.
} 
In the seventeenth century, only the aristocracy and the high-ranking clergy were able to afford lace. The narrowest strip could take months to complete. The fashion of the time, necessitating excessive collars or ruffs, required large amounts of what was a very expensive commodity. Clothing heavily embroidered with gold and silver laces were equally expensive. The royal and religious authorities, especially Finance Minister Colbert, were critical of the expenditure involved, particularly as many of the laces were imported, so that monies were leaving France and not being invested in the French economy. For church leaders the disapproval was primarily social and moral. Pride was a sin, condemned by the Catholic Church, even though the latter was a great patron of lace, unlike the more austere Protestants who were more consistent in their disapproval. ${ }^{87}$ Figure 6 illustrates the abundance of lace that was used in the albs of prelates for example. Ironically, the Huguenots were the most skilled in lacemaking and silk fabrication. When the Catholics sought to impose uniformity of religion, they discriminated against those most likely to aid the French economy and to satisfy their own tastes for luxury. When Louis XIV revoked the Edict of Nantes ${ }^{88}$ in 1685, thousands of skilled lace and textile workers left France to seek religious and political asylum in other European countries.

Because of concerns about social stability, sumptuary laws were introduced by Louis XIV's father, which allowed only the royal family and the aristocracy to wear lace, while creating laws to dictate how these laces were to be worn. This maintained the https://archive.org/details/recueilgnraldes03jourgoog. (accessed 20 November 2014).

${ }^{87}$ Kraatz, Lace and History Fashion, 22.

${ }^{88}$ The edict of Nantes was issued in April, 1598 by Henri IV. It gave substantial rights to the Protestants in what was then a Catholic country. 
hierarchical system of status, which used dress and its embellishment with lace and embroidery as an integral part of one's identity. The edict of 1639 prohibited "placing on the linens and sheets of a bed, any passementeries, laces or cut stitching". Other statues prohibited the use of imported laces in the interiors of carriages. These early anti luxury laws conveyed the king's right to define and "balance the body politic", as much as did Louis XIV's later insistence that his courtiers spend a high proportion of their revenue on court dress. ${ }^{89}$ The sumptuary laws, with their prescriptive detail, also acted as a chronicle of the importance and relevance of lace and embroidery in the language of power. They were largely ignored.

Louis XIV would in fact, introduce tighter controls than anyone before him, as his minister Colbert sought to regulate the French economy, seeking ways to reduce imports, increase exports, (particularly of domestic luxury goods) and so create employment and wealth within France.

To help address the problem Colbert decided that lace production in France should become more commercial and should acquire more style. He proceeded, with the kings' support, to create specialist lacemaking towns, such as Alençon, Quesnoy, Loudun and Rheims. He imported experts and established within ten years a lace making industry to rival the Italians, producing a lace called point de France. During July 1666, Louis XIV bought point de France worth 18,491 livres at the royal manufactories. In comparison, the annual salary of Charles le Brun was 11,200 livres

\footnotetext{
${ }^{89}$ Kraatz, Lace and History Fashion, 60.
} 
and a portrait of the Queen Mother Anne of Austria painted by Beaubrun cost only 750 livres. $^{90}$

Colbert's support for stricter or more strictly imposed sumptuary laws, which had been in existence for many centuries throughout Europe, was thus motivated by the economic theory that by prohibiting the wearing of imported luxury goods the domestic market would improve. By keeping the local currency in circulation rather than exporting it to buy imports, local wealth would theoretically accrue. Colbert's mercantilism in the time of Louis XIV could be considered the economic equivalent to royal absolutism. A new definition of luxury was developing which acknowledged the benefits of domestically produced luxury. Colbert believed that "consumer demand, like the bullion supply, was a fixed commodity." ${ }^{91}$ Colbert's use of sumptuary statutes was focused on building a strong national identity related to economic production and industry within France. Under his leadership the strong association of luxury products with France's national identity was first clearly identified. This has continued throughout history, during the reign of emperors, kings and even republican governments of the twentieth and twenty-first centuries. Louis XIV's use of sumptuary legislation on the other hand, was more for the purpose of controlling the aristocracy politically, than to keep local currency in circulation. $\mathrm{He}$ issued 52 sumptuary statutes. ${ }^{92} \mathrm{He}$ sought to prevent the rich bourgeoisie and aspiring nobles from wearing certain items, which could give them a dangerous sense of their own importance in relation to him-self. Louis XIV, in contrast, increased his

\footnotetext{
${ }^{90}$ Kraatz, Lace. History and Fashion, 52.

${ }^{91}$ Moyer, Johanna B., Sumptuary law in ancient regime France, 1229-1806, 233. http://surface.syr.edu/hst_etd/233. (accessed 24 November 2015).

${ }^{92}$ Louis XV passed some sumptuary laws but was not as prolific as his predecessor.
} 
own opulent displays of embroidery and lace, in order to show himself to be God's peerless representative on earth. ${ }^{93}$

Between 1600 and 1642 over half of the sumptuary laws targeted imported laces. After the ascension of Louis XIV the proportion of sumptuary laws about imported lace rose to 86.7 percent. $^{94}$ During the same period, 80 percent of all sumptuary laws prohibited the use of gold and silver in some way. This included not only silver and gold laces and embroidery but also gilding, and gold fabrics. Clothing restrictions were applied to almost 60 percent of clothing from the beginning of Louis XIV's reign. ${ }^{95}$ In the first decade of Colbert's tenure (1663- 1669), 66.67 percent of all sumptuary laws included restrictions on imported items. This was nearly the same number as those which contained restrictions on gold and silver. ${ }^{96}$ The proliferation of domestic luxury became associated with the growing prosperity of France.

The edict of 27 November 1660, which was posted again on 20 April 1661, stated that subjects should wear only French trimmings and lace, not foreign. ${ }^{97}$ Men were only allowed to wear lace in certain position on their costume, for example around the collar, while women could only wear lace or trimmings around the hem of a petticoat, down the front of gown and around basques and bodices. Symbolic occasions such as weddings and funerals were especially suited to representations of status, and

\footnotetext{
93 Moyer, Johanna B., Sumptuary law in ancient regime France, 1229-1806, 147. http://surface.syr.edu/hst_etd/147. (accessed 24 November 2015).

${ }^{94}$ Ibid. 201.

${ }^{95}$ The last sumptuary law was passed in 1737.

${ }^{96}$ Moyer, Johanna B., Sumptuary law in ancient regime France, 1229-1806, 79. http://surface.syr.edu/hst_etd/179. (accessed 24 November 2015).

${ }^{97}$ http://gallica.bnf.fr/ark:/12148/bpt6k134040c.r=Louis+XIV+1660.langE.
} 
recognition of this fact worked against all efforts, legal or moral, to limit expenditures on lace and embroidery.

This edict was pronounced just before the marriage of the young king, Louis XIV and Marie Therese of Spain, daughter of Philip IV - in other words, a grand affair for which everyone would have been planning the most elaborate toilettes. Molière, the seventeenth century playwright, saw an opportunity for humour in the affair, and wrote a bold tongue-in-cheek eulogy of the edict in his L'Ecole des Maris, which amused the disappointed court. The dialogue shows superb mastery of the metaphorical language of habillement. One of the characters, Sgnarelle, makes a pompous little speech on the sumptuary law, his words of approval offset by the dramatist's unspoken mockery as surely as lace work is offset by the gaps and spaces between the thread:

Oh! Trois et quatre fois soit béni cet edit

"Par qui les vêtements de luxe sont interdits!

"Les peines des maris ne seront plus si grandes

"Et les femmes auront un frein à leurs demandes...."

Oh! Que je sais au roi bon gré de ces decries!

Et que, pour le repos de ces mêmes maris,

Je voudrais bien qu'on fit de la coquetterie

Comme de la guipure et de la broderie $!^{98}$

By the reign of Louis XIV centralised structures had developed for prosecuting sumptuary law violations, so there was indeed a slowing down of consumer demand

\footnotetext{
${ }^{98}$ Molière, L'Ecole des Maris, Act 2, Scene 6.
}

http://www.toutmoliere.net/acte-2,405409.html\#acte_ii_scene_premiere (accessed 20 February 2015). 
and consumption. In Paris, the responsibility for overseeing the execution of sumptuary laws became the domain of the Commissaires of the Châtelet. ${ }^{99}$ Louis XIV and Colbert also issued prohibitions and sumptuary laws on imported lace as part of the general regulations governing the French lace industry. Merchants who sold foreign lace and trimming would be fined 1,500 livres. Between October and December of 1667, only one person, Jeannne Sarazin, described simply as an ouvrière, was convicted of a sumptuary law violation. She was found in possession of one scarf decorated with points de Venise, of two heights of three fingers. ${ }^{100} \mathrm{On}$ March 17, 1668 point de Venise and lace from Genoa was banned. However, such was the desire for gros point de Venise, a desire inflamed by prohibition, that smuggling was a common practice. Some statutes also restricted the use of domestically manufactured lace that was not made under the auspices of the company formed by Colbert. The manufacture of illegal lace was relatively common, as it could be fabricated in the homes of poor workers with inexpensive tools. Penalties for violations were severe. Merchants caught with foreign points were subject to a 3000 livres fine, confiscation of their merchandise and prosecution as "disturbers of the public peace," all for the first offence. ${ }^{101}$

\footnotetext{
${ }^{99}$ Moyer, Sumptuary Law in Ancien Régime France, 1229-1806, 308. http://surface.syr.edu/hst_etd/. (accessed 24 November 2015).

${ }^{100}$ BN, Manuscrits francais 21788(344) cited in Moyer, Sumptuary Law in Ancien Régime France, 1229-1806, 287.

${ }^{101}$ BN, Manuscrits Français 16744, fol. 239. Cited in Moyer, Johanna B., Sumptuary law in ancient regime France, 1229-1806, 208.
} 


\section{Court Dress}

At court, the language of opulence and power was developed with due respect to the structure and syntax of every courtier's dress. Men were required to wear the habit habillé, covered in embroidery and jewels, while women were required to wear the grand habit de cour, also adorned with embroidery, leaving their shoulders bare. Contemporary observers of court dress wrote in lavish detail of the latest fashions. Mme de Sévigné wrote,

M. de Langlée a donné à Mme Montepsan une robe d'or sur or, rebrodée d'or, rebrodée d'or, et par-dessus un or frisé, rebrochée d'un or mêlé avec un certain or, qui fait la plus divine étoffe qui ait jamais été imagine!!! Ce sont les fees qui ont fait cet ouvrage en secret... ${ }^{102}$

Mansel compares these court costumes to a group "installation", with contributions by many workers -tailors, embroiderers and couturiers, producing the one outfit. ${ }^{103}$ The aristocrats of the court spent huge amounts of money on court dress. In 1700, most nobles in Paris invested no more than three per cent of their wealth in clothes, while princes and courtiers spent much larger sums. The grand habit of a minister's wife in 1787 cost 2,049 livres, the equivalent of 2,000 days wages for a worker. ${ }^{104}$ Louis encouraged this expenditure: it was a means of keeping his courtiers magnificent and poor.

${ }^{102}$ Cited in Lefébure, Broderie et Dentelles, 144.

${ }^{103}$ Mansel, Dressed to Rule, 2.

${ }^{104}$ Roche, Culture of Clothing 95, 326. 
Louis went one step further in his manipulation of the dress code to serve his own ends. In 1661 he decided to design a "uniform" of court dress that would be available only to a chosen few, fifty in fact. This accorded great privilege to the wearer, and excused them from the sumptuary laws that had recently been enacted. The new coats, worn by award of a special warrant were called justaucorps à brevet. The blue coat lined with scarlet was worn with a waistcoat and both were embroidered in gold and silver thread. The coat was easily identifiable and became coveted within the court. It gave the wearer the right to follow the king's hunt, and Mansel describes these uniforms as a symbol of sovereignty, as well as badges of pleasure. ${ }^{105}$ Special uniforms were also worn by courtiers who travelled with the king to other residences outside Versailles.

Even before the official move of the court to Versailles in 1682, festivities were enjoyed there, with international dignitaries being invited so they could take back news of France's brilliance to their own courts. Publications were produced to help disseminate imagery of the opulence and wealth of the court, in order to impress neighbouring European countries. As Cardinal Richlieu observed, “Opulence ...is more necessary there (in the king's household) because foreigners recognise the grandeur of princes only by appearances."106

\footnotetext{
${ }^{105}$ Mansel, Dressed to Rule, 56.

${ }^{106}$ Richelieu, Armand Jean du Plessis, Cardinal, duc de, The Political Testament of Cardinal Richlieu, translated by H.B. Hill, University of Winsconsin Press, 2003, 51.
} 
Aside from rules and regal impositions, festivities and theatrical dramas with their specially designed costumes could themselves inspire new fashions. Molière was frequently called upon to write and perform new works, satires and ballets. A skirt by Gissey for the ballet Psyché in 1671 caused a fashion sensation for the decorative use it made of three rows of lace. The ability to mislead others by using déguisement was popularised by Molière in his plays, often written primarily for the entertainment of Louis XIV. Since fashionable dress was required to move up the social ladder, Molière also made frequent use of characters adopting court fashion to achieve their ambitions. His use of the conceit of a change of clothes between men of different stations in particular confirms the importance of clothing and dress as a vestimentary code that could be spoken, and played with. Courtiers were expected to follow the dress codes set by the king himself and Molière alluded to this in many of his plays. Pierre Brissarts' engraving for the 1682 edition of Molière's plays shows several male characters wearing justaucorps similar to that worn by the king. ${ }^{107}$ Molière also used fashion accessories as a signifier of character to his audience. For example in L'École des maris, Lisette describes Sgnarelle, "Ma foi je l'enverrais au diable avec sa fraise." 108 The Spanish ruff (fraise) was in fashion at the end of Henri IV's reign. During the reign of Louis XIII and the early years of Louis XIV, flat lying collars adorned with lace were worn exposing those who still stuck to the Spanish ruff in 1661 as very old fashioned people. ${ }^{109}$ Molière paid particular attention to men's

${ }^{107}$ Dock,S V, Costume and Fashion in the Plays of Jean-Baptiste Poquelin Molière : a Seventeenth Century Perspective (Genève: Éditions Slatkine, 1992), 15.

${ }^{108}$ Molière, L'Ecole des Maris, Act 1, Scene 2. http://www.toutmoliere.net/acte-1,405408.html (accessed 20 February, 2015).

${ }^{109}$ https://archive.org/stream/dramaticworksofm02moliiala\#page/12/mode/2up (accessed 31 January, 2015). 
clothing, more so than women's and Dock suggests that maybe this was because men's clothing went through so many changes during the reign of Louis XIV. ${ }^{110}$

Molière used both figurative and literal references. The figurative often refers to disguise, such as that of the valet Mascarille in Les Précieuses ridicules, who disguises himself as a marquis by wearing large plumes in his hat and lace canons, of exaggerated proportions. In addition to the vestimentary vocabulary referred to in his plays, Molière's personal inventories reveal that the costumes he had made were sumptuous and included gold and silver embroideries and beautiful laces. ${ }^{111}$ Certainly their visual impact was sufficiently obvious to portray the status and personality of the character and to confirm their attitudes to contemporary politics and culture. Above all, costumes had to be luxurious in order to reflect the splendour and glory of the monarch.

Molière's IAD (Inventaire Après Décès) describes the three magnificent costumes of Armande's Psyché:

Item, the costumes for the presentation of Psyché consisting of a skirt of gold linen cloth decorated with three silver laces with an embroidered bodice and furnished with a tonnelet and sleeves of gold and real silver, another skirt of silver linen cloth whose front is decorated with several laces of real silver with a mantle of crape embellished with similar lace and another skirt of green and silver watered silk, garnished with fake lace and with an embroidered bodice, the tonnelet and sleeves embellished with

\footnotetext{
${ }^{110}$ Dock, Costume and fashion in the Plays of Jean-Baptiste Poquelin Molière, 341.

${ }^{111}$ Although it cannot be said if they were real or artificial.
} 
gold and real silver, another skirt of blue English taffeta, decorated with four laces of real silver, appraised together at 250 livres. (Cent Ans 570)

Louis XIV was a master of visual theatre in every aspect of court life. Versailles was not only the home of the officially commissioned plays, ballets and fêtes, it also became a glorious venue for state affairs and the reception of state dignitaries. The king expected a high standard of dress from courtiers who were the extended reflection of his own magnificence and subject to his control. An enforced policy of profligacy was thus the novel means by which he sought to quash rebellion and depress pretension. Saint Simon commented:

He loved above all splendour, magnificence, profusion. This taste he turned into a political maxim, and inspired his whole court to adopt it. It was to please him that one had to throw oneself into gambling, into clothes, into carriages, into buildings and gaming. These were the occasions when he spoke to people. The result was that he tried and succeeded to squeeze the whole world into putting luxury as a point of honour, and for some parties a necessity, and so little by little reduced society to depend entirely upon his favours to survive. Furthermore a court superb in all it did was satisfaction to his pride. ${ }^{112}$

\section{The Language of Lace}

In the sixteenth and seventeenth century, the wearing of lace was more about status than they were about gender. Contrary to more recent practice, lace was worn

\footnotetext{
${ }^{112}$ Louis de Rouvray, Duc de Saint Simon Vermandois, Mémoires, ed. A. de Boislisle, 43 vols. 18791930, vol. XXVIII, "Character of the King", cited in de Marly, Louis XIV \& Versailles, 39.
} 
predominantly by men during the period from 1630 to $1650 .{ }^{113}$ The precise positioning on the body was important. The man's cravat for example, was positioned under the chin, drawing attention to the face and head above, while the cuffs were low on the wrist, emphasising the hands. The two areas of display corresponded with the two most important conveyors of intelligence and expression. ${ }^{114}$

Kraatz writes "this heavy lace sat especially well on men and they adopted it without restraint". ${ }^{115}$ Portraits of elite male figures in armour usually show their sitters not only in heavy armour but also wearing fine linen and lace, usually gros point de Venise, which was still widely popular in the latter decades of the seventeenth century (See figure 16). This lace was three dimensional, and it had a heavier sculptural quality that was perhaps more suited for a male than the lighter laces. Starched cuffs were also extravagant. The poem, La Révolte des Passemens ${ }^{116}$ was published in Paris, in 1661 by Charles Sercy. Composed of prose as well as verse, the poem is dedicated to Madamoiselle de la Trousse who was a cousin to Madame de Sévigné. The author is unknown but is thought to be one of her literary friends, possibly a bas bleus $^{117}$ from the salon held at L'Hôtel de Rambouillet in Paris, home of Madame de Rambouillet. It was inspired by the sumptuary edict of 1660 . It has been a reference for lace historians because of its characterization of the popular laces of the time who are made into characters in the poem. The features of each lace are related to their place of origin and their weaving. The association of lace and war for example, is

\footnotetext{
${ }^{113}$ Kraatz, Lace. History and Fashion, 43.

${ }^{114}$ Walsh, Gros point de Venise, 97.

${ }^{115}$ Ibid.

${ }^{116}$ La Révolte des Passemens, (Paris: Charles Sercy, 1661).
}

http://www.cs.arizona.edu/patterns/weaving/articles/nb30_pas.pdf (accessed 3 March, 2015).

${ }^{117}$ Bas bleus became a metonym for intellectual women, but later became derogatory. 
alluded to in the poem and shown to be one of decorum. The lace cravat was part of the appropriate dress for battle. This may well link up with the old definition of the nobility as those who fight. Thus lace with all its signifiers of wealth, status and provenance was worn by high-ranking officers with their armour in a combination of references to past and present. Lace would have been both appropriate and desirable for a nobility that still identified itself strongly with the military and vice versa.

"Le gentilhomme," writes Capefigue. "allait au feu en manchettes poudré à la maréchale, les eaux se senteur sur son mouchoir en point d'Angleterre, l'élégance n'a jamais fait tort au courage, et la politesse s'allie noblemen à la bravura."118

Masculine elegance decreed that men pose for their portraits with great collars of lace advantageously displayed over breast plates of burnished steel. ${ }^{119}$ (See figure 10) Imported Flemish laces were particularly well adapted to this purpose, being beautifully soft and pearly white, which contrasted well with armour.

${ }^{118}$ Bury-Palliser, History of Lace (New York: Dover Publications, 1984), 167.

${ }^{119}$ Kraatz, Lace. History and Fashion, 42. 


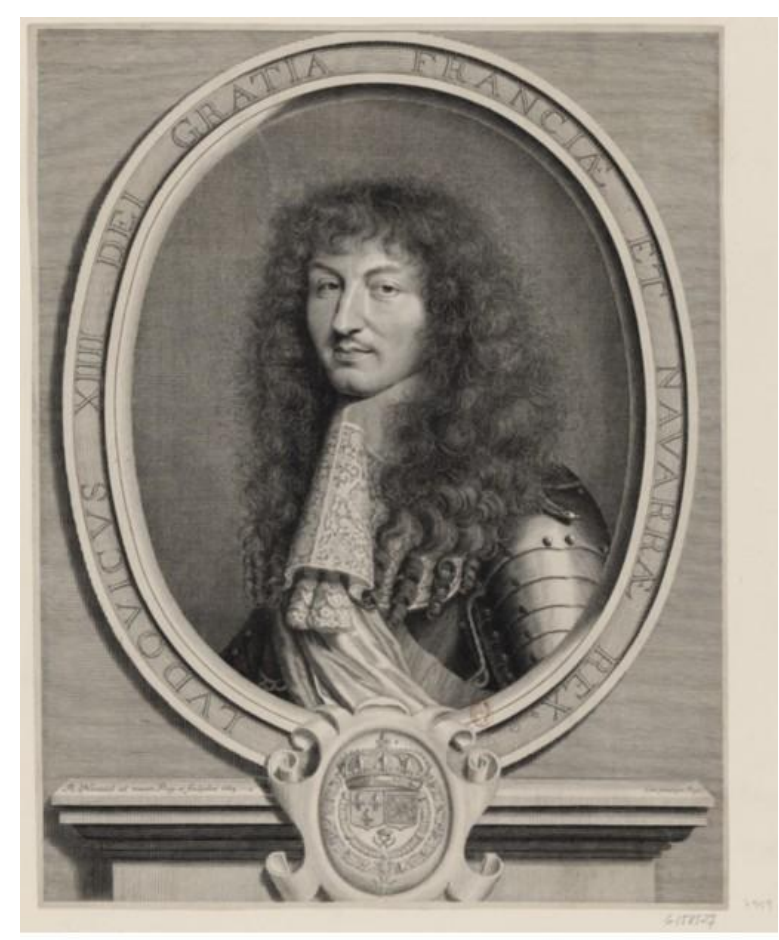

Source gallica.bnf.fr / Bibliothèque nationale de France

Figure10.

Nanteuil, Louis XIV, 1664, Engraving, Bibliothèque Nationale de France.

Contrastingly, the lace at the women's neckline was positioned much lower, drawing attention to the nearly exposed breast, strongly eroticized in the same poem, La Révolte des Passemens. ${ }^{120}$ The lace of the cuff was by contrast, higher up the arm, emphasising the exposure of an area of the body that had been covered for many centuries on high ranking females.

Car peut-on, sans ces deplaisirs,

Satisfaire mieux ses desirs

Que de passer toute sa vie

Dans les lieux qui feroient envie

${ }^{120}$ La Révolte des Passemens, Paris: Charles Sercy, 1661.

http://www.cs.arizona.edu/patterns/weaving/articles/nb30_pas.pdf_(accessed 3 March, 2015) 
Aux esprits les plus delicats

Demeurant tantost sur les bras

Tantost sur la gorge charmante

De Phillis ou d'Amaranthe?

Quel plaisir de toucher à nu

Un beau sein tout nouveau venu! ${ }^{121}$

It was therefore possible to link lace with power and intelligence in men and sexuality in women. The message of sexuality conveyed by the lace at the neckline of women was highly ambiguous. It was ostensibly used to cover up the breast by extending the area concealed by fabric, as in a tippet or bertha. In fact this display of modesty drew attention to that very place on the body it was intended to hide with its semi transparency, more suggestive than either coverage or flagrant exposure. But by not seeming to expose this area a woman could retain her virtuous and pious moral reputation while projecting a certain seductive allure. Lace thus speaks a contradictory language and may hint at conflict between text and subtext, overt practice and covert intention.

It was important that it was clean, well maintained and fashionable, and that it was right for the occasion on which it was to be worn and seen. Lace was considered a suitable gift in a variety of circumstances, not just because of its high cost but because of the wider values it held. Its appropriation and display were crucial facets of its agency. $^{122}$

\footnotetext{
${ }^{121}$ Ibid.

${ }^{122}$ Walsh, Gros point de Venise, 65.
} 


\section{Representation of Lace and Embroidery in Paintings}

In addition to documentation in archives recording all this grandeur, the portraits that were the visual documents of their time provide insights into the representation and visual language of lace and embroidery. In France, the rate of literacy in 1686-90 was around twenty-nine per cent for men and fourteen per cent for women, measured by the ability to write one's signature. It increased to forty-eight per cent for men and twenty-seven per cent for women by $1786-1790 .{ }^{123}$ It follows therefore, that visual signs were a vital medium for communication and propaganda. The inclusion of lace and embroidery in portraiture was particularly telling, and an endorsement of the sitters' identity, complementing the costume and choice of accessories. It also enabled 'false' messages to be communicated, as they were in Molière's plays. For example, the artist could decide to include a lace that was of a very high quality and very expensive that the sitter may not in fact have been able to afford. The image produced would thereby give a deliberately false impression of the status and social position of the wearer. The language of lace in these instances is very much about illusion, about appearances and ways of playing with the common currency of signifiers.

The many portraits of King Louis XIV show him in grandiose costumes, often including lace and embroidery, which dominate the visual space in relation to the features of the wearer. These iconic portraits of royalty tended to accentuate the royal persona rather than the individual. But the viewer had no doubt who the subject was

\footnotetext{
${ }^{123}$ James Melton, The Rise of the Public in the Enlightenment (Cambridge: Cambridge University Press, 20012), 81-82.
} 
because of his regalia. Costume was the key to the showmanship of gesture and the rituals of the body. It enhanced the drama of social theatre played out in Louis XIV's court, from dawn to dusk, and from dressing to undressing, one layer of fabric at a time.

The portrait of Louis XIV painted by Hyacinthe Rigaud was originally commissioned as a gift for Philip V of Spain (See figure 11). The king was so delighted with it, however, that it was never sent. Instead copies were made and it was used as a propaganda tool, the visual signifier of the royal personage, the sign that sometimes could even act as a substitute for his presence. This allowed successful manipulation of his subjects, many of whom would not have been able to read. There is nobility in the antique setting Rigaud has represented with the crimson curtains, framing the solemnity of the Sun King, who wears his coronation robes embroidered with fleurde-lys, and enhanced by lace cravat and cuffs.

A similar portrait was painted of Louis XVI by Antoine-François Callet in 1788, a hundred years later, using a similar stance and costume, similarly showing a profusion of lace at cuffs and collar (See figure 12). 


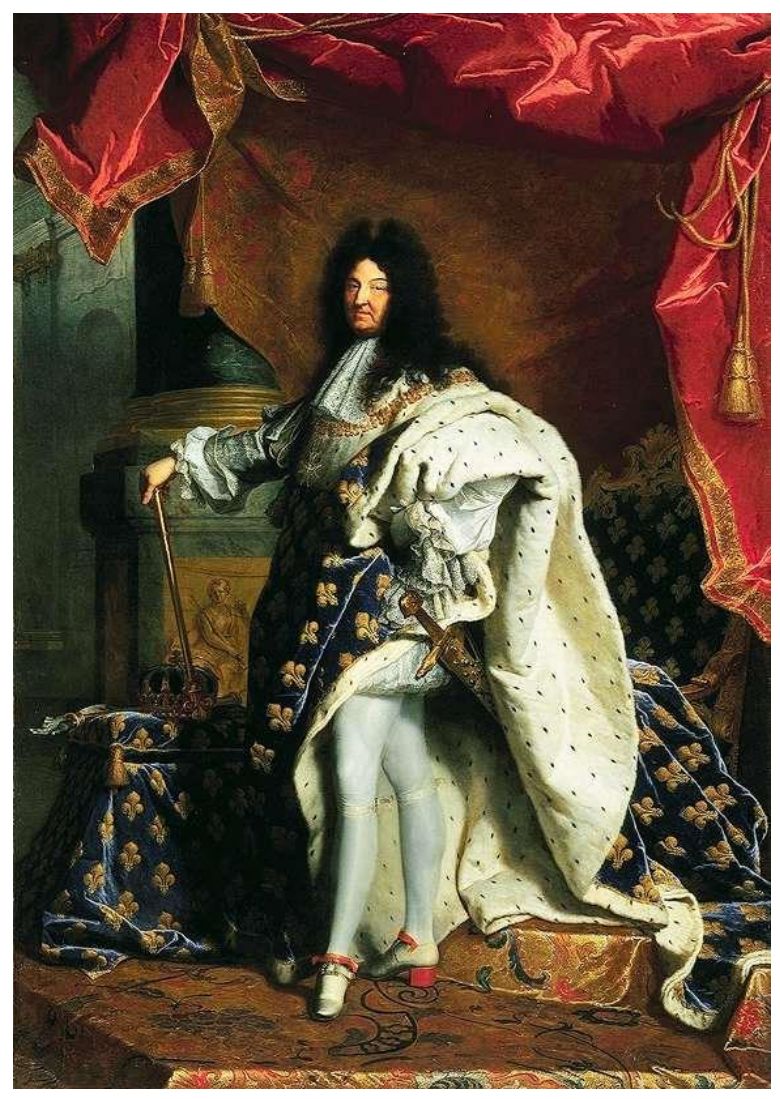

Figure 11.

Hyacinthe Rigaud, Louis XIV, 1701, Oil on canvas, 277 x 194 cm. Châteaux de Versailles et de Trianon, Paris.

Glorification of the kingly personage is the intention - not representation of the person, or the individual apart from his trappings. These portraits would have been replicated and sent out from the court as the official images of the ruler, in the same way photographs of reigning presidents are used in French government buildings, or profiles of exalted personalities are used to legitimize coins.

In most seventeenth-century paintings the embroidery and lace are highlighted, signifying their importance in the message to be imparted or read by the viewer. 


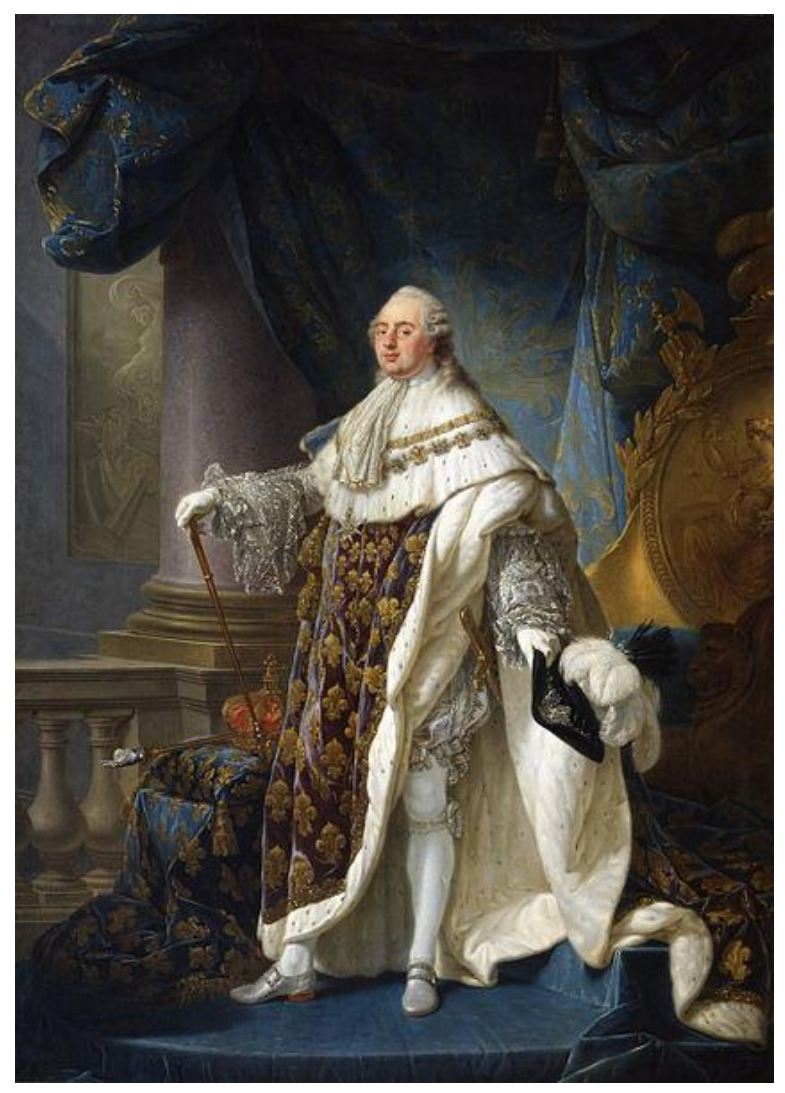

Figure 12.

Antoine-François Callet, Louis XVI, King of France and Navarre, 1789, oil on canvas, 278 x 196 cm. Châteaux de Versailles.

Because the representation of the lace was so vital, the skill of the artist and the techniques that he used draws the eye as much as does his/her subject. Translating the three dimensional lace onto canvas while preserving the textures of the patterns would have been a great challenge to the portrait painters. ${ }^{124}$ Some artists were meticulous in their representation of the details of fabrics and fashions placing equal emphasis on costume, face and background so that the portrait serves as a literal and accurate representation of the language of the clothing. This luxuriance of detail was a particular feature of the baroque paintings. Techniques of light and dark were used to

\footnotetext{
${ }^{124}$ Painters sometimes employed other painters for specific areas of a painting, such as draper painters, but there appears to be no evidence to suggest that there were painters that specialised in lace only.
} 
highlight the lace specifically, creating a play of illuminations and shadows as important as the contours of the face.

In the portraits studied in the course of this research most painters have made a deliberate choice to represent the lace as a virtuoso lace. In other words, it has been represented in such detail that it is often possible to see the precise pattern and hence identify the type of lace referred to. The origin of the lace is more difficult to determine as lace was often reproduced illegally despite the efforts of ministers such as Colbert, and attempts to copy it were made throughout Europe. But the relationship between the representation of the sitter and the kind of lace they were wearing was clearly established.

These royal portraits can be examined using Barthes analysis visual rhetoric. While these paintings show a man finely dressed, with many individual signifiers or accessories, it is the overall connotation that gives the portrait its stature. The reader or onlooker would be able to translate the image portrayed in the portraits based on their own social and cultural experiences.

It is difficult to find paintings of this time, which show the commercial lace-makers and embroiderers themselves. They remained anonymous as creators of the signifying objects of the articles used to adorn the rich.

In contrast to this anonymity of the low class producers of lace and embroidery, the painting of Madame Pompadour by Drouais in 1763, Madame Pompadour at her Tambour Frame, which was the last portrait ever painted of her, shows her confidently engaging the viewer's gaze, while seated at her tambour frame (Fig.13). 
She is seen as a respectable, highly educated and refined woman. Embroidery in the eighteenth century was a valued part a woman's education and there was an expectation that all women, whether of high or low birth would acquire skills in embroidery. For the aristocratic woman, it was seen as a refinement and an indication not only of the woman's education but also of the fact that she had leisure time available to undertake the work.

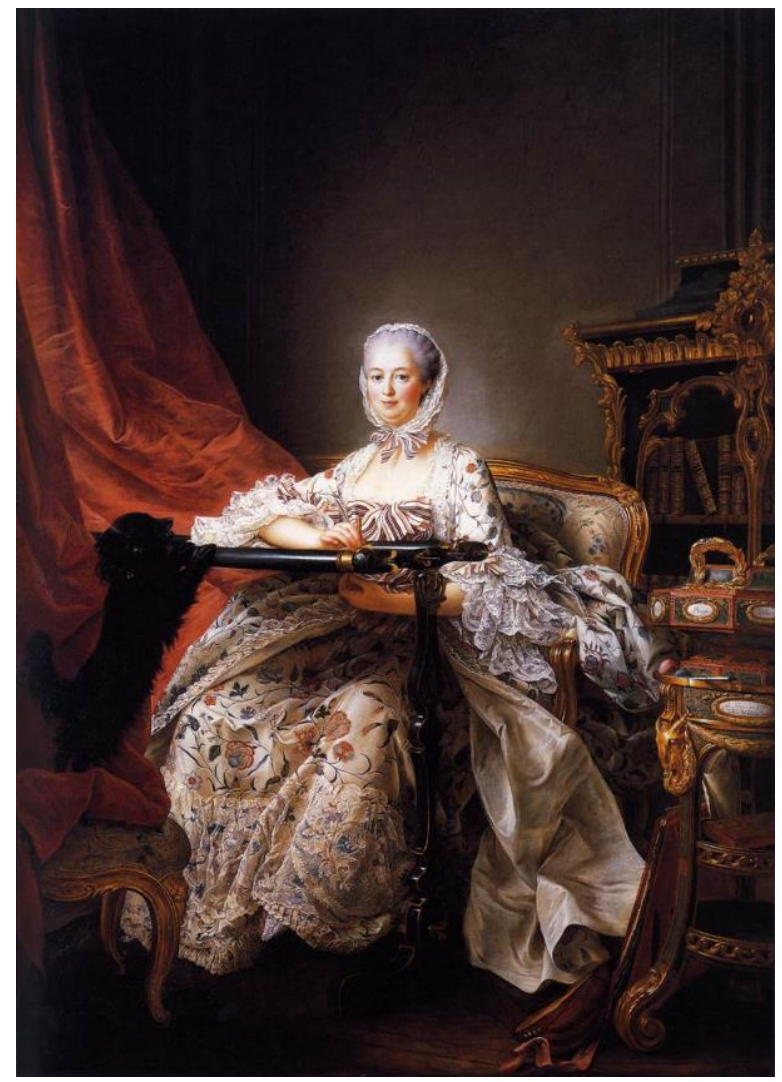

Figure 13.

François-Hubert Drouais, Portrait of Madame Pompadour at her Tambour Frame, 1763-4, oil on canvas, 217 x $156.8 \mathrm{~cm}$. London, National Gallery. 
The painting of Madame Dange by Tocqué, 1753, in which her work with a shuttle making knots to be later embroidered onto dresses is symbolic of her social position as a wealthy woman with time to spare, a matriarchal figure of importance (See Fig. 14). Both of these aristocratic women look directly at the viewer, with the confidence that status allows.

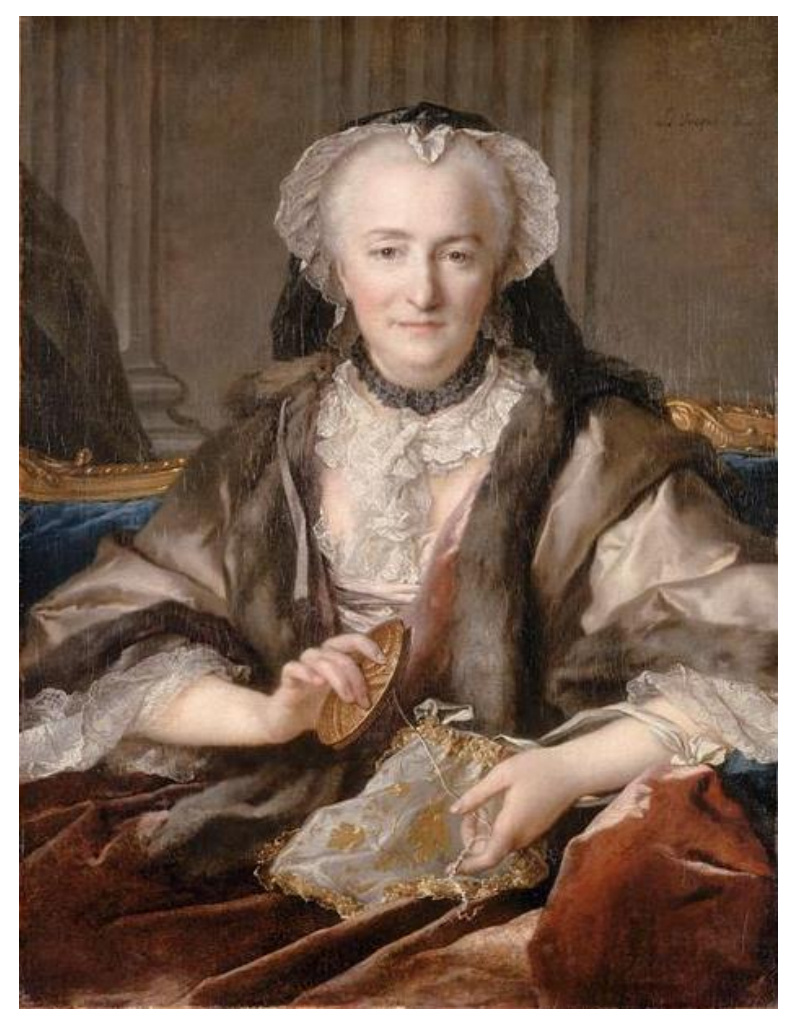

Figure 14.

Louis Tocqué, Madame Dangé faisant les nœuds, 1753, oil on canvas,

$0.83 \mathrm{~m}$ x 0.63m. Paris, Musée du Louvre.

Because artists crossed borders to work on commissions and to find their fortunes, there was also an exchange of teaching methods and techniques. While each painter had his own style there were some techniques that were common between painters and they certainly shared some of their different methods of painting lace. The use of colour, and light and shade contrasts enabled the artists to emphasize the intricate 
patterns of the lace, with its associated symbolic language. But there was also another reason for the exaggerated use of white highlights. Because the lace was worn most often at the wrists and neck, the viewer's gaze was drawn to the hands and face. Soft white hands unblemished by manual labour were another indication of wealth, along with the lace itself. They were also, along with the whiteness of the lace, a symbol of cleanliness, of a moral superiority that matched the superior wealth of the sitter.

\section{Cleanliness}

The display of white lace as a signifier of cleanliness involved quite a different concept of purity to that associated with Pasteur's discoveries of the late nineteenth century. White lace was associated, not with sanitizing hygiene practices, but with moral cleanliness. Vigarello explains:

La propreté au XVII siècle, attachée essentiellement au linge et à l'apparence immédiate - par exemple celle qui s'investit dans l'apparat des objets ou dans le détail des signes vestimentaires -, est bien sûr très différent de celle qui, plus tard, s'investit dans la preservation des organismes ou la défense des populations. Exactement d'ailleurs comme une "société de cour" valorisant les critères aristocratiques de l'apparence et du spectacle, est différente d'une société “ bourgeoise” plus sensible à la force physique et démographique des nations. ${ }^{125}$

For all their sumptuary laws and sophistication, the hygiene practices of the seventeenth and eighteenth centuries were less 'advanced' even than those in

${ }^{125}$ Georges Vigarello, Le Propre et le Sale: L'hygiène du corps depuis le Moyen Âge (Paris: Éditions Seuil, 1985), 15. 
medieval times. Medical theory was based on Girolamo Fracastoro's original work on Contagion, Contagious diseases and Their Cure, published in 1546, which believed that germs, or miasmas, floated in the air and entered the body through the skin. Water was considered especially dangerous because it opened the pores in the skin making one more vulnerable to disease. Cleanliness and hygiene were therefore sought in white linen, as the flax from which it was made was believed to draw out dirt from the skin. Throughout the seventeenth century, writes Georges Vigarello, in Le Propre et le Sale, it was thought that linen had special properties that enabled it to absorb sweat from the body. ${ }^{126}$ The invention of linen marked the sartorial apogee of an upper class society in which appearances were all-important. The representation of lace by artists as a very white material was a reflection of the association of the lace, not only with wealth but also with moral cleanliness, purity and by extension, godliness. Religion and cleanliness have both been connected to the pursuit of purity, and many religious rituals center on physical cleanliness as a part of religious devotion. $^{127}$

Caring for clothes, particularly laces became synonymous with caring for the body. The shirt began to emerge from under clothing as seen in a collar and cuffs. Frequently in the seventeenth and eighteenth century these were made of lace and were bleached as white as possible. Vigarello has reasoned that the exposing of the fabric worn closest to the body allowed the wearer to make a statement about the quality and purity of what the clothing otherwise concealed. ${ }^{128}$ Eventually the lace

\footnotetext{
${ }^{126}$ Ibid., 73.

${ }^{127}$ Jesse Preston and Ryan Ritter, “Cleanliness and Godliness: Mutual Association between two kinds of Personal Purity,” Journal of Experimental Social Psychology 48, (2012), 1368.

${ }^{128}$ Vigarello, Le Propre et le Sale: L'hygiène du corps depuis le Moyen Âge, 62.
} 
became so extensive, with collars so large they nearly met the cuffs, and huge canons that flounced over boots, that the 'intimate' became part of the external garment. The spectacle of cleanliness and its association with propriety thus became part of a person's social display. This show of purity was especially important in court society. The more extravagant lace was an exemplary sign of cleanliness and the king in this regard, as in all others, was shown to be the epitome of virtue. The public display of the dressing and undressing of Louis XIV confirmed and elaborated his superior cleanliness, while his demands for formal court dress with opulent displays of white lace revealed a determination to unite extravagance with the display of virtue and moral worth. Cleanliness, and virtue were indeed a matter of appearances.

Washing lace was a lengthy and costly exercise and could be performed only by those who could afford it. Special laundresses were required to take care of the lace and to re-starch it using goffering irons and crimping irons as pleats and folds were lost in the washing process. The ability to pay either for the professional cleaning and care of lace or for servants with the necessary skills could be directly related to the cleanliness and condition of the lace worn and thus signalled a social position of some rank.

Most laces of the seventeenth and eighteenth century were in reality a creamy ivory colour or a pearly white, determined by the flax thread from which they were made. This is not how they were represented in the portraits of the time. ${ }^{129}$ Artists used a white lead paint to exaggerate its snowy whiteness, which was otherwise obtainable,

\footnotetext{
${ }^{129}$ Walsh, Gros point de Venise, 51.
} 
up to a point, through a careful process of bleaching. Linen flax does not take dye well but it could be bleached. It was washed, boiled and then laid out in the sun. The process could be repeated several times. Another technique was soaking the lace in buttermilk. Heavily bleached threads however, lost their sheen. Vigorous bleaching ultimately destroyed the thread, so that many laces made using any of the aforementioned bleaching techniques were unlikely to have great durability. Haarlem in Holland was famous for obtaining an almost bluish whiteness to the laundry. Some thought this was from the damp climate, the combined action of the sun and moon, the quality of the river water it was washed in, the use of whey in the final rinse or the type of ashes used in the wash. But even the most intense bleaching was unlikely to produce the 'blue-white' shade we see in paintings. Etienne Sabat believed that the Dutch had a secret product called vedasse, but it is more likely that they used indigo which was a profitable trade. Originally outlawed by Henri IV, Colbert reduced the restriction on its importation. ${ }^{130}$ The French considered the Dutch bleaching methods the best. Saint-Simon wrote," The Comtesse de Fürstenburg was prodigal in all sorts of expenditure, and possessing such perfect lace and linen, bleached only in Holland.",131

According to meticulous notes kept by Jean Héroard, the French court physician, Louis XIV's father, was not given a bath until he was almost seven. For gentlemen, a wardrobe full of fine linen smocks edged with lace or undershirts to enable a daily

\footnotetext{
${ }^{130}$ Françoise de Bonneville, The Book of Fine Linen, 52.

${ }^{131}$ Ibid., 53.
} 
change was a more important sign of hygiene and sophistication, than was regular bathing. French playwrights, Racine and Molière owned thirty each. ${ }^{132}$

\section{Language of uniforms}

Louis XIV died in 1715 and was succeed by his great grandson, Louis XV. A Regent was appointed, Philippe II, Duke d'Orléans until Louis XV was old enough to take control in 1723. His reign was characterised by lost wars, religious feuds and many clashes between the court and Parliament. Louis had lived at Versailles since 1722, marrying Marie Leszczyńska in 1725 . He did not embrace the pomp and ceremony of court life in the same way as Louis XIV and while he used the old king's apartments for state functions he was happier residing in private apartments.

Louis XV nonetheless continued the tradition of using uniforms and livery symbolising the master/servant relationship. Through the vehicle of embroidery he created this livery for his courtiers and servants alike. As was the case under Louis $\mathrm{XIV}$, these were also related to hunting activities. These uniforms became symbols of sovereignty as well as symbols of pleasure. Jean-Baptiste Oudry painted the king's deer hunt and the only way to distinguish between the king and his courtiers is by the blue ribbon of the order of Saint Esprit. Princes of the blood such as the duc d'Orléans could also order coats for their own courtiers, using embroidered livery as a sign of subservience.

${ }^{132}$ Vigarello, Le Propre et le Sale: L'hygiène du corps depuis le Moyen Âge, 83. 
But by the late eighteenth century, men's costume was following the trend of the English frac, a simple dark frock coat that cost around one tenth of the cost of the habit habillée. The frock coat carried no adornment or signs of distinction or differentiation, therefore no embroidery. By 1785, Delpierre has noted that French men wore the simple frac, or frock coat during the day and then changed into the habit habillé for the evening, going from en chenille, like a caterpillar, to bursting forth in all their butterfly glory. ${ }^{133}$ More simple dress became evident for both men and women some years before the French Revolution, so new codes of social differences in dress were already beginning. ${ }^{134}$

Louis XVI's reign was marked by the outbreak of the French Revolution. At the opening of the Estates General in 1789 , which was regulated by the dress code of the previous meeting in 1614 , the differences in dress were highlighted and the political language that this implied had suddenly become inflammatory. Louis XVI blazed with diamonds on his Order of the Holy Esprit, with his embroidered habit habillé, sword, buttonholes, epaulettes and shoe buckles. ${ }^{135}$ Deputies of the first estate wore the costume of their ecclesiastical rank. Nobles wore black silk or cloth trimmed with a gold braid, a lace cravat, white stockings a feathered hat and swords. The Third estate wore black cloth, black stockings and short-back cloaks. Although merchants had been given the right to wear swords in 1767, the third Estate deputies were not.

\footnotetext{
${ }^{133}$ Delpierre, Se vêtir au XVIIIe siécle, 43, cited in Mansel, Dressed to Rule, 65.

${ }^{134}$ Paul Lacroix, XVIIIe siècle:institutions, usages et costumes, 1875, 486, cited in Mansel, Dressed to Rule, 65.

${ }^{135}$ Morel, Bernard, les joyaux de la couronne de France, 1988, 228 cited in Mansell, Dressed to Rule, 66.
} 
This was a humiliation. ${ }^{136}$ The dress code was one of the first aspects of political and social life that the revolutionaries addressed in the following months. The differentiation between classes that embroidery and lace had enabled was to be put aside in the quest for democracy.

Between 1782 and 1791 the number employed in the embroidery industry fell by half. ${ }^{137}$ The wearing of the frac was one of the main contributors to the change, but it was also influenced by less formal presentations at court and less use of liveries and coats of arms. In 1791 a petition to the National Assembly stated that embroiderers were going bankrupt, fashion shops were closing, and dress makers were sacking three quarters of their workers. ${ }^{138}$

While the National Assembly enacted legislation that decried discrimination based on what people were wearing there was a reticence to take advantage of this and to wear clothing with freedom of choice in case it was identified as being counterrevolutionary. ${ }^{139}$ The French revolution empowered the lower classes, but lace and embroidery was not worn for fear of being associated with the pre-Revolutionary symbolism of aristocracy that these adornments portrayed. After several years of tension between the rich and the poor, a confrontation of dress was again used as a political tool. The sans-culottes revolutionaries were easily identified by their long trousers, short jackets and bonnets rouges, a uniform of the poor. On the other side,

\footnotetext{
${ }^{136}$ Ribeiro, The Art of Dress: Fashion in England and France 1750-1820, 45.

${ }^{137} \mathrm{C}$ Beaulieu, Histoire du commerce de l'industrie et des fabriques de la soie, Lyon, 1838, 101-3, $107-$

8, 111, cited in Mansell, Dressed to Rule, 71.

${ }^{138}$ Roche, Culture of Clothing, 315.

${ }^{139}$ Valerie Steele, Paris Fashion: A cultural history (Oxford: Oxford University Press, 1988), 48.
} 
nobles wore fracs, black coats embroidered with the cross of Saint Louis, but were expelled from the palace by national guards in tricolour uniforms. ${ }^{140}$ The National Guard demanded that Louis XVI wear their uniform, but he was reluctant to do so, even though anyone not wearing was to be expelled from the court. Everyone was identifiable by the 'uniform' that they wore just as the military uniform of the battlefields, the precursors of livery, identified the rank and allegiance of the soldier. As the palace was later stormed by revolutionaries, the Swiss gardes discarded their uniforms while fleeing so they would not be identified as royalists. ${ }^{141}$

From 1800, uniforms became popular in all European courts, both civil and military uniforms. By proclaiming an official or military rank, greater respect and obedience was observed. The French Republic, which ruled from 1795 to 1799, adopted uniforms for all legislators and officials. The Directors were instructed to wear an elaborate uniform of a red silk habit manteau with gold embroidery fringes. ${ }^{142}$

Once Napoleon overthrew the Directory, crowning himself Emperor in 1804, he reestablished court dress and encouraged patronage of the embroiderers once again. His military uniforms increased in splendour and dress became increasingly regal. Throughout the army he introduced elaborate uniforms, using embroidery, lace, plumes and even bear-skins. An official uniform was also introduced for princes, marshals, court officials and grand officiers. ${ }^{143}$ Each service in the household of the Emperor's household was assigned a different colour. Napoleon I also promoted lace

\footnotetext{
${ }^{140}$ Mansell, Dressed to Rule, 72.

141 Ibid.

${ }^{142}$ Mansell, Dressed to Rule, 78.

143 Ibid., 80.
} 
and there was a revival of sorts, but not to the extent that embroidery was now utilised on the civil and military uniforms.

Court dress over several centuries was classical in form, for men it combined military stiffness with aristocratic luxury. ${ }^{144}$ The habit habillé was heavily adorned with embroidery and men found it most uncomfortable. Fortunately it was only necessary to wear it at court. Embroidery was once again an important vehicle of display at the court of the Empire. It replaced the ribbons and trims that had been made popular by the marchands de modes with skillful embroidery on the new high-waisted court dresses. The embroidery designs incorporated the Napoleonic bee ${ }^{145}$, and a range of classical and exotic motifs. The materials included gold and precious stones, spangles, coloured silks, foil and bugle beads. ${ }^{146}$ (See Fig.15). Napoleon wanted to reform France into a "complicated hierarchy of civil uniform to give dignity, discipline and structure to a new society." ${ }^{, 147}$ But society wanted democracy. And people wanted to dress as individuals.

${ }^{144}$ Steele, Paris Fashion: A cultural history, 52.

${ }^{145}$ Napoleon, following the medieval custom of king's having a personal emblem, chose the gold bee. He discovered that when the tomb of Childeric, the founder of the Merovingian dynasty who died in 481 , was opened in the mid-seventeenth century it was found to contain hundred of gold insects, bees and cicadas.

${ }^{146}$ Ribeiro, The Art of Dress: Fashion in England and France 1750-1820 (Yale: Yale University, 1995), 122.

${ }^{147}$ Ibid., 99. 


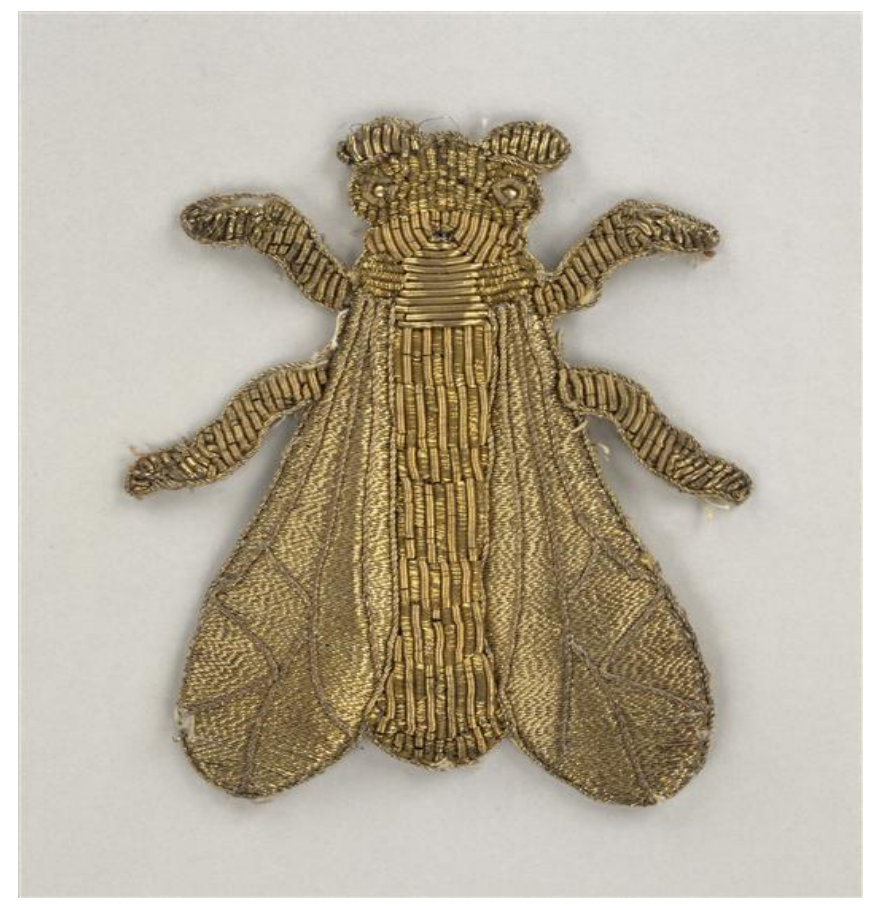

Figure 15.

One of a series of seven embroidered bees, thought to be destined for the Throne room at Fontainebleau, 19th century. Gold threads on canvas, $0.15 \mathrm{~m} \times 0.95 \mathrm{~m}$, Rueil-Malmaison, chateaux de Malmaison et Bois-Préau. (ORMN 


\section{Chapter Four: Changing Attitudes and the Domestication of Needlework}

As the social revolution of the mid-eighteenth century began to unfold, the philosophers of the Enlightenment began to challenge the traditional hierarchical structures of the political, educational and social orders. Instead of a reliance on ecclesiastical authority and social conventions, the new order proposed reason, science, and mathematical formulae to explain the world. The threat to the clergy and the nobility, together with the demise of the notion of absolute monarchy, became a direct threat to the survival of lace because of the generous patronage the privileged classes had proffered to the lace-making industry. This patronage had helped to maintain the popularity of lace and its association with class and power. At the same time as the rituals of the court and aristocracy were frowned upon, however, the middle classes wanted to compete with and surpass the refinement of their former superiors. Through the changing patterns of consumption and fashion therefore, lace became more freely available to the bourgeoisie, while losing its value as an exclusive commodity and mark of distinction.

Enlightenment philosopher, Jean-Jacques Rousseau, was to urge a return to nature in his writings on the Origin and Bases of Inequity of Men and in his discourse on education, Emile ou L'Education, written in 1762. These writings influenced the separation of domestic and public, male and female and had implications also for embroidery and lace. For the first time, the fabrication of embroidery and lace became exclusively associated with femininity and domesticity. Lace changed from being a 
signifier of wealth and status to a mere feminine trimming, and women were confined to the domestic sphere, helping create a gendered economy. ${ }^{148}$

In his work Emile ou L'Éducation, Rousseau clearly argued for the separation of domestic and public, male and female. Insisting that women were innately drawn to needlework as an extension of a primary impulse to adorn themselves, Rousseau also intimated that the opposite must be true for men. ${ }^{149}$ In other words, men were naturally eager to occupy themselves with political and social action. And while advancing the notion that it was in a woman's nature to adorn herself for the purpose of seducing men, he also firmly put the role of making the 'adornments' into the hands of women. Embroidery lost the status it enjoyed under the control of the guilds. It was no longer considered an appropriate masculine form of political and social action.

L'aiguille et l'épée ne sauraient être maniées par les mêmes mains. Si j'étais souverain, je ne permettrais la couture et les métiers à l'aiguille qu'aux femmes et aux boiteux réduits à s'occuper comme elles. ${ }^{150}$

Rousseau's reference to the 'lame' who found themselves reduced by their weakness to plying a needle, clearly shows his judgement of the so-called second sex, while the skill associated with thread work is relegated to a compensatory activity reserved for the less powerful or incapacitated members of society. Rousseau also passed a moral

\footnotetext{
${ }^{148}$ Anne Ratzki-Kraatz, "The Elegant Art of Dress," in An Elegant Art: Fashion and Fantasy in the Eighteenth Century, ed. Phil Freshman (New York, Harry N. Abrams, Inc., 1983) 107.

${ }^{149}$ Crowston, Fabricating Women, 64.

${ }^{150}$ Jean-Jacques Rousseau, Emile ou L'Education, French Kindle edition, 3919.
} 
judgement on the lace and embroidery because of their association with luxury. He believed that traditional sumptuary laws only encouraged luxury: "it is not by sumptuary laws that luxury will be exterminated...Sumptuary laws stimulate the desire by constraint rather than extinguishing it by punishment."

The writings of Jean-Jacques Rousseau were published at a time when the values of cultured society were being critically examined and society was ripe for reform. His observations fed into a long running debate about feminine taste and the natural and innate characteristics of the feminine or of 'femininity' particularly amongst the bourgeoisie. It is notable that these observations were made largely by male writers and philosophers. Jones suggests that Rousseau:

Affected a compelling substitution of a comfortable, attractive, and eroticized domestic realm within which women's taste could flourish, in lieu of the contested honnête domain of polite discussion of letters and creative productions within the salon. He rejected the current objects, practices and effects of women's taste in France. He condemned the public role of the aristocratic and bourgeoisie women in the courts and salons of the ancien régime. ${ }^{152}$

Women were thus condemned for their love affair with la parure of fashion and luxury, including the wearing of lace and embroidery as adornments. Their natural

\footnotetext{
${ }^{151}$ Rousseau, Jean-Jacques, Considerations sur le Gouvernement de Pologne (Geneve, 1772), 282, cited in Moyer, Sumptuary Law in ancient régime France, 370.

152 Jennifer Jones, “Repackaging Rousseau: Femininity and Fashion on Old regime France," French Historical Studies 18, no.4 Autumn, 1994, 939.
} 
beauty and good taste alone should seduce the male sex, which was seen to have been led astray by the luxurious tastes of their destined help-mates. Instead:

Donnez à une jeune fille qui ait du gout, et qui méprise la mode, des rubans, de la gaze, de la mousseline et des fleurs; sans diamants, sans pompons, sans dentelles, elle va se faire un ajustement qui la rendra cent fois plus charmante que n'eussent fait tous les brillants chiffons de la Duchapt. ${ }^{153}$

Women readers of this time were ambivalent about Rousseau's new philosophy of domesticity with its focus on the feminine ideal of delicacy, purity and naturalness. Hamerton suggests that just as the revolutionaries readily adopted and co-opted elements of Rousseau's political ideas for their own purpose, some individual women consequently did the same with his ideas about their supposed innate talent as purveyors of taste, once freed from their wayward desires for luxury. Women did not need to consider all of Rousseau's arguments to find the idea of a "tasteful, eroticized domestic imperium" attractive during a period of increasing consumerism. ${ }^{154}$ In effect, Rousseau was affirming that the practices of creating embroidery and lace in the home, that were to be used for 'tasteful' adornment, played a role in signifying piety, virtuosity and morality and could therefore be associated with the new feminine and domestic and the natural role of women in homemaking. Given other legal and

\footnotetext{
${ }^{153}$ Rousseau, Emile, French Kindle edition, 7897.

${ }^{154}$ Katherine Hamerton, Rousseau and the New Domestic Art of Women's Taste, In Proceedings of the Western Society for French History. Columbia College, 2009, 6.

http://quod.lib.umich.edu/w/wsfh/0642292.0037.007/--rousseau-and-the-new-domestic-art-of-womenstaste?rgn=main; view=fulltext
} 
social restrictions on women's lives, this model had considerable attractions in dignifying and rendering virtuous acts of creativity, such as embroidery undertaken at home, fashionable consumption, and family nest-building:

Il n'y a pas un ouvrage à aiguille qu'elle ne sache faire, et qu'elle ne fasse avec plaisir; mais le travail qu'elle préfère à tout autre est la dentelle, parce qu'il n'y en a pas un qui donne une attitude plus agréable, et où les doigts s'exercent avec plus de grâce et de légèreté. ${ }^{155}$

Female readers identified with Rousseau's literature because in many cases he was vocalising their own aspirations and desires. In an age when adultery was an accepted practice and loveless marriage matches were common, Rousseau's philosophy seemed to give women a moral dignity. ${ }^{156}$ However, not all women responded enthusiastically to his views. While appreciating his eloquence and persuasive arguments, some women writers were wary of the restrictions implied in his treatise. Mme de Staël and Mme Roland for example credited Rousseau with successfully promoting stronger family ties, but their own active political lives gave the lie to his judgement that women were better off at home. Louise d'Epinay challenged his narrow vision and Wollenstonecraft, an English feminist, responded strongly in her work The Rights of Women, to Rousseau's writings. ${ }^{157}$

\footnotetext{
${ }^{155}$ Rousseau, Emile or L'Education, French Kindle edition, 8438.

${ }^{156}$ Trouille, Sexual politics in the Enlightenment, 5.

${ }^{157}$ Ibid.
} 
As a consequence of Rousseau's analysis, which offered its own version of a society mythologized by signifiers, embroidery began to be interpreted as a handcraftneither an art nor a valued profession — and a symbol of a leisured domestic lifestyle. No longer was the language of the stitch one of power and wealth. Now it spoke of piety and good taste, at home and in fashion. Metallic laces, extravagant white laces and embroidery were seen as ostentatious and unbecoming and their association with the aristocracy made them an anathema following the French Revolution in 1789. The new woman in Rousseau's philosophy could continue to wear lace and embroidery but she did so with discreet goût rather than in order to display wealth and power. ${ }^{158}$ In other words, embroidery and lace were acceptable adornments of simple, natural femininity. This refocusing on the notion of taste rather than class was both empowering and restricting:

Fashion was defined as frivolous and ephemeral and consigned to the realm of goût rather than to the realm of art or politically powerful realm of luxe, to the salon and the toilette rather than the Conseil d'etat, to public promenades in the Tuileries and the shops of the Palais-Royal rather than to learned academies, and to the concerns of women rather than those of men. Fashion was harnessed, tamed, and made intelligible by linking it to femininity and defining it as one of the principal, innate, and relatively unimportant concerns of all women. ${ }^{159}$

\footnotetext{
${ }^{158}$ Jones, Repackaging Rousseau: Femininity and Fashion on Old regime France, 949.

${ }^{159}$ Katherine Hamerton, "Rousseau and the New Domestic Art of Women's Taste," Proceedings of the Western Society for French History, 2009.
} 
As an extension of his views on how women (and men) should behave in society, Rousseau advocated a change in the education of children. Children should be less constrained and receive more nurturing from their mothers. In accordance with the view that childcare was the province of women, was the mise en valeur of the mother and daughter bond through time spent undertaking needlework, the mother passing on to her daughter the virtues of feminine industry. ${ }^{160}$

\section{Changing Representations: The new language of lace and embroidery in painting and in written texts.}

By the late eighteenth century these new attitudes to needlework began to be expressed in other mediums. Painting in particular, represented the position that stitching held in society. Portraits of the aristocracy embroidering in their leisure time were contrasted with genre paintings of the ouvrières who still largely produced the work in significant quantities.

Typically, the genre paintings of a lower-class woman undertaking the work, shows the subject with head bowed as if submissive, quite unlike the direct gaze of the aristocratic Madame de Pompadour. The painting by Jean-Baptiste-Siméon Chardin, for example, The Embroiderer, painted in 1736, shows a middle class female, a domestic servant rather than a member of the French court, taking wool from a basket for her embroidery (see fig 16). This painting was commissioned and painted as one of a pair, the other depicting a young male draughtsman, painting in a studio, copying a painting that would have been part of his apprenticeship assignments (see fig.17).

\footnotetext{
${ }^{160}$ Parker, The Subversive Stitch, 130.
} 


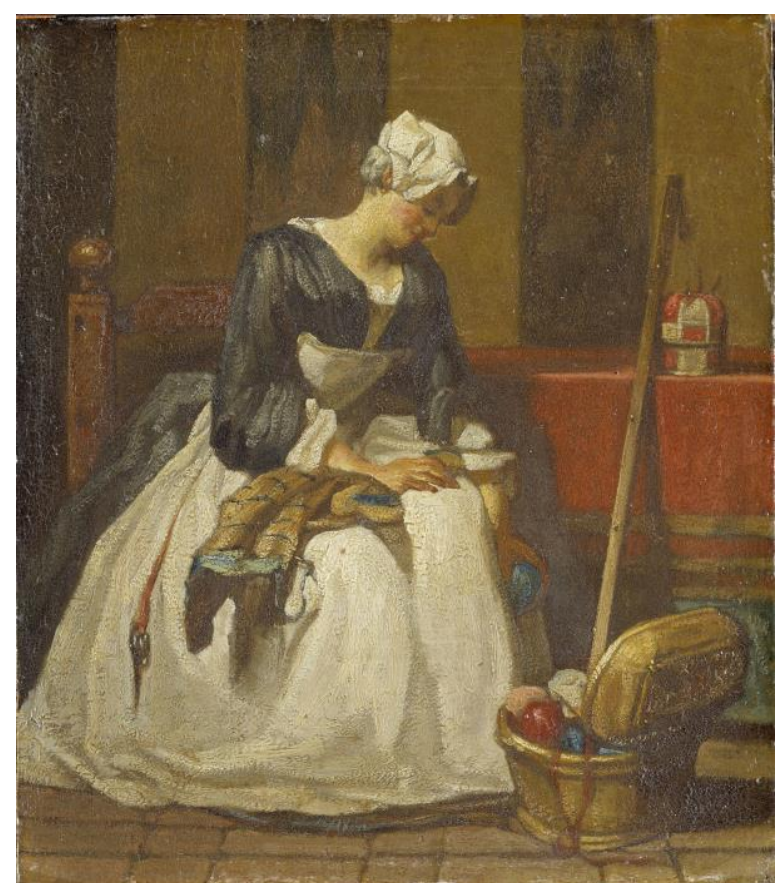

Figure 16.

Jean-Baptiste-Siméon Chardin, The Embroiderer, 1736. oil on canvas, 15.5 x 19 $\mathrm{cm}$, National Museum, Stockholm, Sweden.

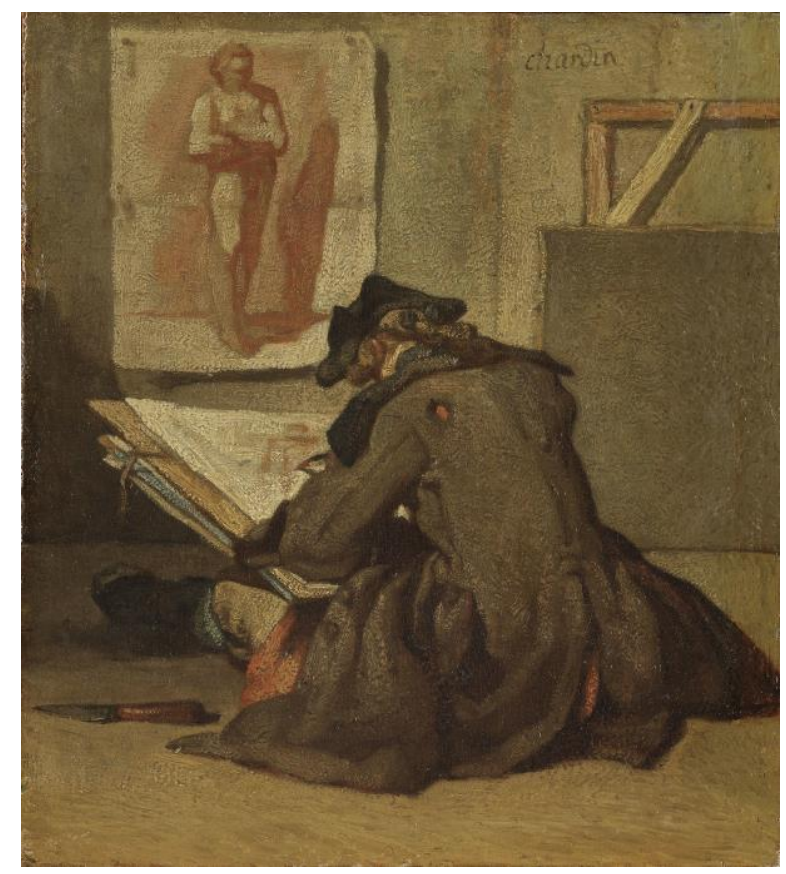

Figure 17.

Jean-Baptist-Siméon Chardin, Young Draughtsman copying an Academy, 1736, oil on canvas, 15.5 x $19 \mathrm{~cm}$, National Museum Stockholm.

Christie's auction notes, written in 2013 when a version of The Embroiderer sold for 
$\$ 4,000,000$, commented on the differences between these two paintings executed in 1736. The two paintings together, commissioned as a pair, demonstrate Rousseau's binary oppositions of male versus female, art versus craft and professional versus domestic. The catalogue also commented on how "they also contrast engaged absorption in one's actions with the distracted absorption of the embroiderer - the interruption of work for a deep but momentary immersion in one's own inner world."161 The artist's representation of the embroiderer suggests at once the image of a woman enjoying the meditative aspects of stitching to the extent that she has closed her eyes to enjoy a moment of reverie, and the fatigue perhaps attendant on her daily tasks. Her posture, however, clearly reinforces Rousseau's feminine ideal of thirty years later. As Donaldson writes:

the characteristic posture of the seamstress evokes at the same time modesty and submission to a domestic ideal: a young woman is generally seated, her hands occupied with the needlework, her head bowed in silent concentration. ${ }^{162}$

Chardin's genre painting of a bourgeoisie mother checking her child's work, illustrates the growing representation in paintings of the increasingly important relationship of mothers and their children and the association of embroidery with femininity. This was to be encouraged and emphasised by Rousseau. (See Fig. 18)

\footnotetext{
${ }^{161} \mathrm{http} / / /$ www.christies.com/lotfinder/paintings/jean-baptiste-simeon-chardin-the-embroider-5649665details.aspx. (accessed 5 December, 2014).

${ }^{162}$ Donaldson-Evans, M., "Pricking the male ego: pins and needles in Flaubert, Maupassant, and Zola", Nineteenth Century French Studies, Spring -Summer 2002, 254.
} 


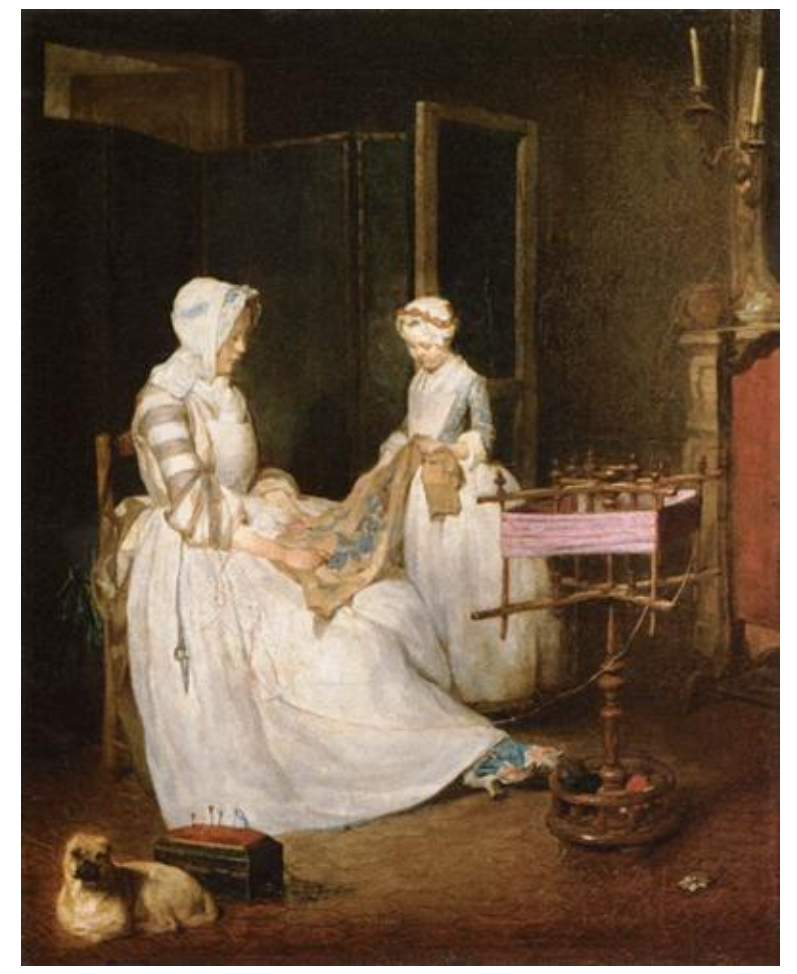

Figure 18.

Jean-Baptiste-Siméon Chardin, La Mère laborieuses, 1740, oil on canvas, 39 x $49 \mathrm{~cm}$. Paris, Musée du Louvre.

Nineteenth-century paintings, such as the Embroidery Lesson by Hughes Merle, painted in 1850, illustrate the continuing importance of knowledge of needlework in a woman's education, as this was understood by the growing bourgeoisie. A women's education began from a very young age. This painting gives an insight into the centrality of the mythology of the family and the 'mother and child' relationship, as defined by Rousseau in his earlier writings on the inter-relationship of nature and nurture in education. 
The mother and daughter relationship was idealized, particularly in bourgeois families, as upholding a certain vision of femininity. Women now became constrained within the domestic household, where family ties, particularly with children were most important. At the time, sewing classes were mandatory for girls, despite the educational reforms of Ferry in the 1880 s, much as military exercises were mandatory for boys. Due to industrialisation there was, in fact, a declining need for girls to learn needlework, so the skill was increasingly associated with something that was neither powerful, nor practical. It was, in short, a harmless amusement, an approved way of expressing femininity. A rising birth-rate and a decline in the mortality of children coincided with this new ideology of motherhood. ${ }^{163}$ In the nineteenth century, Gauguin, Renoir and Cassatt were artists who each painted middle-class women sewing. Some were portraits, such as Renoir's painting of his son as a child, sewing. But with the exception of Renoir's painting, all reinforced and continued the feminine stereotype first associated with thread work by Rousseau in the preceding century.

By the mid-nineteenth century when these paintings were being produced, commercial success was naturally important to the livelihood of the artists. Having lost the sponsorship of royalty and the aristocracy following the Revolution, artists had to rely on their own marketing. The upwardly rising bourgeoisie, who appreciated paintings of domestic family life and narratives, which affirmed their own traditional and family values, was the most lucrative market. It was therefore logical that painters depicted embroidery as an integral part of the upper class and the bourgeois lifestyle.

\footnotetext{
${ }^{163}$ Parker, The Subversive Stitch, 128.
} 
Some members of the lower socio-economic groups still relied on working in the clothing industry, but the mechanisation of industry meant that instead of producing labour-intensive embroidery and lace at home, women were now set to work in clothing factories. Seamstresses and other thread workers were not so evident in French genre paintings of the time, factories and large workshops being nether whimsical nor feminine. The representation of the language of lace and embroidery was still, therefore, complex and even contradictory.

Alongside these new pictorial representations were written works that depicted the same socio-economic phenomenon. The nineteenth century saw the emergence of new novelists who wanted to reflect on the values and social environments that had emerged as a result of the age of industrialisation and consumerism. Zola's novel Le Rêve, ${ }^{164}$ the sixteenth novel in the series Les Rougon-Macquart, Histoire naturelle et sociale d'une famille sous le Second Empire, was published in 1888. As a naturalist writer, Zola intended this series to reflect the social, economic and political conditions of the time through the experiences of one family under the Second Empire. The novel is set in the years 1860-69. Even though the Revolution had overturned the power of religion, the climate at the end of the century when the novel was written was one of an increased spirituality and a turning away from naturalism, to a more emotional symbolism. The influence of William Morris on the arts and hence on associated thread work, had arrived from England. The Arts and Crafts movement was acknowledged in France as a movement of ideals and a reaction against

\footnotetext{
${ }^{164}$ Zola, E. Le Rêve. Paris: Bibliothèque-Charpentier, 1913.
} 
industrialisation. In the preparatory dossier of Le Rêve, a note from Fr. Hamon on embroidery states:

Le movement Arts and Crafts, en réaction à l'industrialisme et à l'immoralité sociale de la societé victorienne, propose un mode de production fondé sur l'association des artistes et des artisans dans des Guildes qui empruntent leur dénomination à un Moyen-Âge idéalisé. ${ }^{165}$

Sigmund Freud, the celebrated psychoanalyst, had begun studying the 'unconscious' and Zola's inquiry into the "au-dèla, le transcendent, l'inconnu et le rêve," 166 in writing the novel, Le Reve, links his understanding of the 'unconscious' with the art of embroidery. Zola thus sought to illustrate the new scientific ideas, including those of Freud, when exploring the effects of nature and hereditary on a person's character. He does this specifically in the novel, by using the meditative and contemplative aspects of embroidery as a socially acceptable means of subduing the passionate nature of the heroine of the novel, Angélique, which was inherited from her birth mother:

Il s'agira d'un rejet sauvage des Rougon-Macquart, transplanté dans un milieu mystique et soumis à une culture spéciale qui le modifiera. Là est l'expérience scientifique, mais ce qui fera la curiosité de l'œuvre, ce sera qu'elle pourra être mise entre toutes les mains, meme entre celles des

\footnotetext{
${ }^{165}$ Preparatory dossier of Le Rêve (Gallica/BNF), Cited in Scarpa, L'éternelle juene fille une ethnocritque du Rêve de Zola (Paris: Éditions Champion, 2009), 22.

${ }^{166}$ Marie Scarpa, L'éternelle juene fille une ethnocritque du Rêve de Zola (Paris: Éditions Champion, 2009), 21.
} 
jeunes filles. Il s'agit d'un poème de passion, mais d'une chasteté absolue, à l'ombre d'une vieille cathédrale roman. ${ }^{167}$

Angélique, was found as a crying baby on the steps of the cathedral by the Huberts, a childless couple whose profession was that of embroidery-chasubliers, and who were descended from a line of ecclesiastical embroiderers, dating back to the fifteenth century. Thanks to their nurturing, Angelique becomes a highly skilled embroiderer with special talents, who becomes obsessed with La Légende dorée, a tale of Christian saints and martyrs. Her dream was to be saved by a handsome rich prince and so marry and live happily ever after, much in the same way as the virgin martyrs have had their faith tested before entering heaven and marrying Jesus. The following extract describes the special talents that Angélique had for embroidery, and the way she transferred her passion into the very works that she stitched. The novel is also contains many references to the symbolism of the church and virginity depicted through embroidery.

Angélique était devenue une brodeuse rare, d'une adresse et d'un goût dont s'émerveillaient les Hubert. En dehors de ce qu'ils lui avaient appris, elle apportait sa passion, qui donnait de la vie aux fleurs, de la foi aux symboles. Sous ses mains, la soie et l'or s'animaient, une envolée mystique élançait les moindres ornements, ell s'y livrait toute, avec son imagination en continuel éveil, sa croyance au monde de l'invisible. (....) En ce moment, la chasuble à laquelle travaillait Angélique était une

\footnotetext{
${ }^{167}$ Lettre de Zola à J. Van Santen Kolff, 22 janvier 1888, cited in Scarpa, L'éternelle juene fille une ethnocritque du Rêve de Zola, 24.
} 
chasuble de satin blanc, dont la croix se trouvait faite d'une grebe de lis d'or, entrelacée de roses vives en soie nuancé. Au centre, dans une couronée de petites roses d'or mat, le chiffre de Marie rayonnait, en or rouge et vert, d'une grande richesse d'ornemens. ${ }^{168}$

The symbolism of colour enriches the religious implications of the embroidery's mythology.

Le blanc pour les confesseurs et les vierges, le rouge pour les apôtres et les martyrs, le noir pour les morts et les jours de jeûne, le violet pour les Innocents, le vert pour toutes les fêtes; et l'or aussi, d'un fréquent usage, pouvant remplacer le blanc, le rouge et le vert. ${ }^{169}$

Zola draws on the traditional uses of embroidery in religious garments of the church to give historical weight to his Rousseauesque concern with female virtue. Early Christian priests wore white, associated with sacredness and with purity, and these associations recur throughout the novel. ${ }^{170}$

Through his brodeurs-chasubliers, the Huberts, Zola was able to propose relationships to religion and virtue, and also to reverie for his day dreaming Angélique, thus combining a range of key attitudes to needlework prevalent in the late nineteenth century. The profession of embroidery for his characters was a deliberate choice. Zola undertook a great deal of research and his preparatory dossier contains

\footnotetext{
${ }^{168}$ Zola, Le Rêve, 56.

${ }^{169} \mathrm{Ibid}, 58$.

${ }^{170}$ Because of this relationship between purity and white it was important that any white worn should be spotlessly clean.
} 
many references to the work of Saint-Aubin. Chapter three of Zola's book provides detailed accounts of the techniques and material used in Angélique's work. By giving his heroine Angélique such talent in embroidery, he provides an acceptable vehicle for her to express her natural passions, so that the flowers become like living things, while multiplying the signs that empower readers to read and translate the embroidery itself:

Au fond, la broderie permet à Zola de concilier la part du "rêve" et la part du “réel". Mais pas seulement à ces niveaux intentionelles où il se place de lui-même, esthétiques, artistiques et techniques. En effet, ce qui nous semble avoir été négligé jusqu'ici dans les commentaires du roman, c'est l'idée que très vite, pour l'écrivain, ce n'est plus le brodeur qui "donne" l'au-delà mais Angélique elle-même. C'est elle artiste, c'est elle la mystique. Si la broderie, en cette fin de XIX siècle, “cesse d'être un passetemps pour demoiselle pour devenir un art" celle de Zola, elle , est bien l'art d'une demoiselle: dans la broderie d'Angélique, c'est toute son éducation ( son destin de femme) que l'on va lire. ${ }^{171}$

Even as French women became simultaneously emancipated and entrapped by industrialisation, so French male writers of the time, Zola, Maupassant and Flaubert wrote of the domesticity of needlework in their writings. The association with piety and virtue were still extolled, through the virtuous women who undertook it, and the ill-fated, vengeful woman who did not. Donaldson Evans considered Flaubert's Madame Bovary in this light, for it makes a link between the inability to stitch and the

\footnotetext{
${ }^{171}$ Scarpa, L'éternelle jeune fille une ethnocritique de Rêve de Zola, 25.
} 
incalcitrant, vengeful character of a woman only interested in sewing as a seduction: ${ }^{172}$

Mademoiselle Emma tachait à coudre des coussinets. Comme elle fut longtemps avant de trouver son étui, son père s'impatienta; elle ne répondit rien; mais, tout en cousant, elle se piquait les doigts, qu'elle portait ensuite à sa bouche pour les sucer. ${ }^{173}$

Obviously Emma is not a skilled stitcher. She orders most of her trousseau from Rouen instead of stitching it herself and she discards her tapestry while exclaiming, “A quoi bon? Quoi bon? La couture l'irritait." She doesn't bother to hem her bridal gown, which is far too long. Emma is frustrated at not having the money to employ her own domestic servant to undertake this work and the emphasis on her lack of skill shows her unable and unwilling to undertake the necessary domestic tasks, which were her lot in life. Emma's reluctance and lack of education in these matters reflects badly on her 'nuture' and her 'nature.' It infers an ineptitude as well as an insubordination.

Through representations in art and literature in the nineteenth century, eighteenth century attitudes to embroidery and embroiderers were thus confirmed and links with femininity, piety, virginity, domesticity, simplicity, fragility, submission and

\footnotetext{
${ }^{172}$ Donaldson-Evans, Pricking the male ego:pins and needles in Flaubert. Maupassant, and Zola, 2.

${ }^{173}$ Gustave Flaubert, Madame Bovary (Paris: Éditions Gallimard, 2001), 61.
} 
compliance underlined. Embroidery had not yet been designated as a handicraft but it was now widely regarded as a feminine activity. 


\section{Chapter Five: Patterns of Identity}

At the turn of nineteenth century, an increased awareness of regional heritage and culture was accompanied by a new interest in the costume that expressed them. Prior to the Revolution, inter-regional communication was limited by roading and transport difficulties. Following the Revolution the birth of a new French nation called for a degree of uniformity throughout the country. In response to the consequent pressure to conform, areas such as Bretagne, where a local patois was spoken and which had regional traditions, strove to retain an identity that would differentiate itself from this new enforced national identity.

This new preoccupation with regional identity versus 'national' was accompanied by imagery, paintings and photography of the professional lace-makers and embroiderers who helped create it. In Bretagne for example, lace-makers were seen working in large groups, traditional lace-making schools were illustrated and lacemaking was seen as being a communal affair of the local village. The vocabulary of embroidery was extended to include regional symbols, such as the chain of life, the sun and the planets, ferns and fish, and different regional stitching techniques and practice. Embroidery in Bretagne continued to be undertaken by men and women. Symbols were also adapted by embroiderers from motifs seen in French fashion, now being transmitted to regional areas through fashion magazines.

Leading these activities that celebrated regional culture was not the rising bourgeoisie but the working class people who had hitherto been anonymous in the history of thread work. Now they were being depicted in paintings and recorded in photographs. 
In the early twentieth century, travelling male artisans used to come to local villages, often with one or two ouvriers or family members, to help in the work. They stayed on farms, in kilns or in barns. Even though the work could be undertaken at their atelier, they continued to travel to outlying farms, thus maintaining close contact with local communities. Up until the 1920s, Anne-Marie Soubigou, descended from a family of tailors from the district Plougastel-Daoulas, herself continued to host female couturiers, at her home, inviting them to work outside, sitting on the ground, on a blanket, undertaking embroidery, dressmaking, repairs and trousseau work. ${ }^{174} \mathrm{Head}$ tailors and embroiderers were usually men in these travelling groups of artisans. The stitching of heavy wool, hemp, and linen certainly required a firm and strong hand for pushing and pulling the needle through the fabric, and this left women free to do the finer work.

The artisan's work was worn locally and helped confirm the development of a regional costume that remains in place today. By maintaining the traditions of this hand work, these skilled workers continued to enrich their own cultural heritage. Thus,

par le style des décorations obtenues, la broderie est.... l'expression de traditions culturelles particulières à chaque peuple et s'il arrive qu'une technique soit rapportée, elle prend aussitôt un caractère original. Certainement parce qu'elle identifie le vêtement en même temps qu'elle le décore. On s’aperçoit bien ainsi que costume égale coutume. ${ }^{175}$

\footnotetext{
${ }^{174}$ Cario, Hélène and Viviane Hélias. Broderies en Bretagne (Coop Breizh, 2007), 36.

${ }^{175}$ Maguelonne Toussaint-Samat, cited in, Cario, Hélène and Viviane Hélias. Broderies en Bretagne, 6.
} 
Following the Revolution and increased industrialisation, local economies were now able to use textiles and materials that had fallen in price. While fashion changes in Paris had reduced the demand for embroidery, (revived for a short time by the patronage of Napoleon in the early nineteenth century), the increase in local cultural expression was most clearly evident from the middle of the nineteenth century through to the beginning of the twentieth century. By 1862, workshops were equipped with sewing machines and the profession became more organised, with embroidery ateliers in Bretagne in particular flourishing.

In France as a whole, however, lace had also lost its status and wealthy fashion leaders of the nineteenth century preferred simpler materials that better reflected the ideals of the time. In spite of the patronage of the Second Republic, the textile industry was also affected by industrialisation and new social structures. Mechanisation allowed for the fabrication of tulle, firstly in England and then in France from 1816. It was adopted avidly by the towns of northern France. By the 1830s machine-made lace was able to copy closely the previously exclusive bobbin made laces. Lefébure commented rather scornfully on this machine-made lace in 1887:

c'est du métier, ce n'est pas de l'art. L'art est absent partout où manque la vérité, partout où le calcul remplace l'émotion, partout enfin où l'on ne 
sent pas vibrer une intelligence derrière la main qui travaille et dont les hésitations même ont un charme particulier. ${ }^{176}$

However, the demise of lace made by hand was to enable the emergence of a machine made lace that was to help revive the local economies of Bretagne. Interestingly, there was no previous history of handmade lace in this region, and it was only in the middle of the nineteenth century that machine lace appeared and became the visual language par excellence that expressed the uniqueness of local identity.

Paris still dictated overall fashion trends. However, thanks to greater communication via better roading and the distribution of printed matter such as fashion magazines, Parisian culture was constantly challenged by local and regional individuality, and the appearance of local idiosyncrasies. ${ }^{177}$ This applied to many aspects of local heritage, including dance, art and literature, as well as costume. As de Planhol affirms, "It seemed that the ineluctably triumphant pressure from the capital, in itself roused local suspicions, pride and resentment." 178

The new regional focus on patrimony and cultural heritage was at clearly at odds with the cultural unification being promoted by the French government. Like the kings of the ancien régime, they wanted France to be considered a strong centralized "nation." Language was identified as a vehicle for unification and the call for the French

\footnotetext{
${ }^{176}$ Lefébure, Broderie et Dentelles, 313.

${ }^{177}$ Planhol, Xavier de, A Historical Geography of France (Cambridge: Cambridge University Press, 1994), 276.

${ }^{178}$ Ibid.
} 
language to be spoken by everyone was ratified in 1880 , when education was made compulsory. In the mid nineteenth-century forty per cent of people were illiterate and by 1863 , twenty-five per cent still spoke regional patois but did not speak French. ${ }^{179}$ Everyone was thus exposed to the French language in the classroom, together with the notion of France as a Republic. It seems that this only intensified the search for new expressions of individuality. At the outset of the Revolution in the late eighteenth century, there was no distinctive local dress, but soon dress became an important marker of identity, copied to a degree from the fashions of the bourgeoisie but ultimately made individual by the adornments of embroidery and lace, that differed from village to village. This was the patois of stitch.

\section{Breton Costume}

Traditional Breton costume at the turn of the nineteenth century, recognised as a unique cultural asset, was becoming a point of convergence for multiple political and economic investments. According to historian Patrick Young, it was also being identified as a vulnerable asset, needing to be protected and promoted, as it was seen as an iconic attraction within an ever growing and socially diversifying international tourist commerce. ${ }^{180}$

\footnotetext{
${ }^{179}$ Ibid., 279.

${ }^{180}$ Patrick Young, "Fashioning Heritage: Regional Costume and Tourism in Brittany, 1890-1937." Journal of Social History, Spring 2009, no. 42, 3, (2009), 633.
} 
Regional costume tended to be characterised by garments that were traditionally worn for special occasions and rituals, for church and weddings, not the unadorned, worn and heavy garments that the Bretons wore routinely for their working day. Visitors to the region were particularly drawn to the embellishments of embroidery, lace and ribbons worked into the Breton coiffes, complex arrangements of hair, and lace bonnets that varied from village to village. With increased communication via roads and expanded commerce, new fashion styles, and the more readily available luxury items enabled the communities to be more creative in the costume they wore, just as these developments brought more visitors, or purists, to see and appreciate what they were doing. New fashion and the ability to use more interesting materials at a reasonable price influenced changes in regional costume in the same way that fashion changed in the larger centres. Bretons began to vary the types of embroidery, colour and techniques used, and these variations came to represent a particular locality. Nicknames were applied to local areas that became associated with the regional embroideries. For example, glazic or petits bleus. The petits bleus originates from the sale of excess stocks of the cloth used for blue uniforms from the military stores in Brest that were sold in the markets and surrounding countryside. ${ }^{181}$ Glazic embroidery, often sewn on thick wool, has distinctive colours, types of stitch and patterns that make it easily identifiable and different from other nearby localities. The patterns stitched became complex and varied. By the early twentieth century, sixty-six styles of costume were identified in Bretagne, with 1200 variations, and fifty-five different styles of lace coiffes. ${ }^{182}$

\footnotetext{
${ }^{181}$ Broderies en Bretagne, 63.

${ }^{182}$ Planhol, A Historical Geography of France, 299.
} 
Traditional dress, while recognized by outsiders as a marker of cultural cohesion and continuity, and often viewed as 'picturesque' was practically difficult to wear in the changing environment of industrialisation and emigration of locals to larger centres to find work. ${ }^{183}$ The arrival of magasins ${ }^{184}$ in the local towns spread a taste for more modern dress, which influenced the demise of wearing traditional regional costume. By the end of the nineteenth century it was obvious that a new initiative was needed to preserve the culture of costume in Bretagne.

Interested parties came from French tourism, and were joined by artistic and cultural communities who all wanted to preserve the regional costume as "an enduring national culture with a significant resistance to French republican identity". ${ }^{185}$ At the same time its preservation protected a "component of French regional patrimony", where patrimony refers to cultural assets that have been recognised by the State. ${ }^{186}$ So, in the 1920s and 1930s, thanks to this intervention Breton cultural traditions were made available to a growing public audience of tourists, while the state simultaneously made clear its views on separatist sentiments. Local costume was collected and displayed at new museums. On the one hand this caused concern because of the risk of reducing the meaning of "traditional costume to contrivance, nostalgia and petrification". ${ }^{187}$ But on the other, the new museums were able to

${ }^{183}$ Young, "Fashioning Heritage: Regional Costume and Tourism in Brittany, 1890-1937." Journal of Social History, Spring 2009, no. 42, 3, (2009), 634.

${ }^{184}$ Material goods were now sold in large retail stores that had large glass windows and visible displays of fashion. Consumer spending increased particularly amongst women. Traditional costume was also not practical for every day wear.

${ }^{185}$ Young, Fashioning Heritage: Regional Costume and Tourism in Brittany, 1890-1937, 635.

${ }^{186}$ Ibid.

${ }^{187}$ Ibid., 636. 
conserve and preserve fine examples of local tradition and industry for posterity. Jean Charles Brun, President of the Fédération Régionaliste Française, (FRF), had high hopes that the costume would also retain its local vitality and relevance and was ready to embrace tourism as the most effective way of maintaining focus on Bretagne's cultural heritage, while boosting the region's economy. Museum display for Brun was a means to an end.

With the increasing number of tourists visiting the area, there came an expectation that traditional dress would be on display for sightseers, in areas where there had been a decline in everyday wearing of this dress, tourists consequently turned up at special festivals and Sunday church, following the lead of tourist guide-books. While Breton's were happy to be identified as sincere and pious individuals, the tourists' desire for authenticity was now turning into a mediated experience, that left the community feeling that they were like the exhibits in the museum on public display. ${ }^{188}$ Some locals were so fed up with being photographed in costume; they began to charge for a photograph to be taken.

There were advantages to this new development. The first organized festival was held in 1905 at Pont-Aven. The Fêtes des Fleurs Ajoncs was held at the height of the tourist season in July and its success guaranteed a continuation of similar festivals around the region. Cultural heritage now started to become associated with performance. "The fête populaire, grounded in shared communal experience and transmission was giving way to the fête folklorique, an event based more on the affirmation of heritage, accommodated by political and cultural elites and by 
commercial concerns." ${ }^{189}$ These events became especially popular after World War I and were mediated not only by the locals but also by Office National du Tourisme, which brought the efforts and interests of local, regional and national bodies together. The festivals that resulted from this collaboration, particularly the major fête at Quimper, were hugely successful and ultimately were even supported by Breton Nationalists, who agreed that the identity of the culture and region had not been compromised. Elite members of the community were encouraged to wear traditional costume in public whenever possible, so that the costume became a costume of a pays, or region, rather than it being associated with a particular social class. ${ }^{190}$ At the same time as the fêtes were encouraged, control was exercised by regional cultural bodies to ensure that the events did not become too commercialised. At the 1934 Congress of Regional Costume in Nice, it was decided that, "only natives or current residents of the region in question be allowed to don traditional costume during these events, to avoid masquerades." 191 In fact, the principal consumer at these fêtes, even into the post-1945 era, was local Bretons themselves, who used the gathering as a form of self-representation, and expression of their local belonging. Gradually, the celebration of identity extended to the émigré Breton population in Paris, who undertook their own cultural performances within the city.

Since World War II the fetes have continued, but now there is a more commercially based stewardship, which regulates the events. A few artisans remain who strive to

\footnotetext{
${ }^{189}$ Ibid., 639.

${ }^{190}$ Ibid., 642.

191 "Voeux du Congrès du Costume Régional à Nice," MNATP, Fonds Charles Brun, Boîte 14, Dossiers Divers: Le Costume Régional, "Articles de Journaux de 1914 à 1937." Cited in Young, Fashioning Heritage: Regional Costume and Tourism in Brittany, 1890-1937, 643.
} 
maintain the techniques and patterns of stitching associated with the emergence of regional costume, and serving as a language of identity since the early nineteenth century. Fetes have assisted in this challenge by exposing the embroidery to a wide audience. While there are no traditional embroidery ateliers remaining, a few local artisans continue to create coiffes and embroideries from traditional designs, while also incorporating traditional techniques into contemporary design and fabrication, thus enabling the knowledge base to continue to be passed on. Handmade lace is now very rare and most of the new coiffes are made from machine made lace. In 1995 Pascal Jaouen opened a school of embroidery at Quimper where he teaches traditional techniques of glazic embroidery, bigoudène embroidery, beading, point de Beauvais, and the lunéville technique with a hook. His passion is to conserve Breton culture, by teaching traditional techniques and producing contemporary fashion embellished with embroidery and lace.

Embroidery on vests, shirts, skirts and jackets have played an important part in the language of cultural identity in Bretagne. The lace coiffes have given Bretagne a point of difference. Many other regions of France have used regional costume in this way but Bretagne is a prime example of the continued endeavours of a regional community to preserve their local culture with its particular accents expressed in embroidery and lace. 


\section{Chapter Six: The Language of Haute Couture: the Expression of Excess in a Pragmatic World}

The origins of haute couture can arguably be traced back to the development of the industry of luxe, by Jean-Baptiste Colbert and the court of Louis XIV. Developing industries such as the silk trade in Lyon and the lace centres of Alençon were what enabled France to become the centre of trade in luxury items in Europe. From the elaborate court dress of Louis XIV, to the extravagant costumes devised by Madame Rose Berthin for the young Marie-Antoinette, France has a long history preoccupation with fashion and of the heavy expenditure it so often entails. Haute couture, a luxury product only available in France, is the ultimate contemporary vehicle of embroidery and lace's socio-economic message.

Up until 1848, couturiers had to conform to the wishes and demands of their clients, and there was little opportunity for creativity. Many of the designs and ideas that their clients wanted were gleaned from the pages of conservative fashion magazines such as Le Cabinet des Modes, founded in 1785. These magazines were a powerful influence on the fashion of the day. Charles Worth however, had a different vision for fashion, and one that largely reversed the client/couturier hierarchy in the history of fashion. Worth is considered the founder of haute couture in Paris. Having moved from England in 1858, he opened his own atelier at 7, rue de la Paix, with an associate, Otto Bobergh. Worth saw himself as an artist, not an artisan, and quickly established himself as a designer of luxurious, original clothing. His approach to design was innovative and refreshing. Clients were required to come and visit him at his plush salon, where they could preview evening dresses in rooms specially 
illuminated. He also used live models to present designs to private clients, with seasonal shows at his own atelier. Each garment was identified with a designer label. He dressed members of European royal families, actresses and rich Americans, who often arrived on the continent by private steamship, and who were routinely charged higher prices than their European counterparts. Such was the attraction of this new style of personal service and craftsmanship, however, that they paid his exorbitant prices without demur.

Worth's focus was on quality in his made-to-measure garments, and on the expensive, richly patterned textiles, heavier than conventional dress silks, from which they were made. Embroidery and lace were used as edgings or borders and were considered embellishments rather than an integral part of the garment's design. Embroidery applied as a passementerie, often matched the fabric to which it was applied, the wealth of detail in the fabric being more important than the cut and structure of the design. Marcel Proust wrote of Odette de Crécy upon her first meeting with Swann in À la recherche du temps perdu, that she gave the impresssion of being a «femme l'air d'être composée de pièces différentes mal emmanchées les unes dans les autres; tant les ruchés, les volants, le gilet suivaient en toute indépendance, selon la fantaisie de leur dessin ou la consistance de leur étoffe". ${ }^{192}$ This slightly waspish judgement was nonetheless perceptive in its recognition that the textiles mattered more to designers like Worth, than the structure of the garment.

${ }^{192}$ Marcel Proust, Du côté de chez Swann, Chapter 2. https://ebooks.adelaide.edu.au/p/proust/marcel/p96d/chapter2.html (accessed 28 January 2015). 
Designers who followed Worth, such as Madeleine Vionnet and Elsa Schiaparelli would use embroidery as an integral part of the artistic whole. The ostentatious display of rich materials associated with Worth's dress reflected the desire of the bourgeoisie to show off their wealth. In this respect, Worth's couture and his use of brocades, fabrics with woven patterns, and passementerie, were very much of their time. New designers, such as Jeanne Paquin, Jean Patou, Paul Poiret, Madeleine Vionnet and Cristóbal Balenciaga, were nevertheless all inspired by Worth's example of the couturier as a creator rather than as a lackey to prevailing tastes and fancies. Poiret was especially bold in this regard. "In painting there was Cubism, futurism, primitivism," say art historian Kenneth Silver, "in fashion there was Poiret."193 It was with the actions of the eccentric Poiret that fantasy as well as opulence entered into the language of Parisian haute couture. At his celebrated costume spectacle of mille et deuxième nuit in 1911, held at his palatial home, his wife and muse Denise, was released from a gilded cage, minus a corset, wearing a lampshade tunic over harem pants (See Figure 19). She was then chased around the garden by Poiret with a whip. The garden was transformed into a sultan's harem, through the careful placement of exotic plants and birds. Poiret loved excessive parties and exuberant fashions and became an international celebrity. ${ }^{194} \mathrm{He}$ chose to serve in the army for World War I but by the time of his return after the war, fashion had moved on.

\footnotetext{
${ }^{193}$ Cited in Vanity Fair, Toujours Couture, www.vanityfair.com/style/features/2009/09/couture200909 (accessed 26 January, 2015).

${ }^{194}$ http://www.metmuseum.org/exhibitions/listings/2007/poiret/the-thousand-and-second-night.
} 
By the end of les Années Folles, the taste for fantasy and excess had been extinguished, but the precedent for the sometimes eccentric and extreme designs of late twentieth century and early twenty-first century had been established.

Between World War I and World War II, clients such as Peggy Guggenheim, Josephine Baker, Helena Rubenstein and Colette chose to wear the designs of couturiers such as Christian Dior, Coco Chanel and Schiaparelli, who all continued

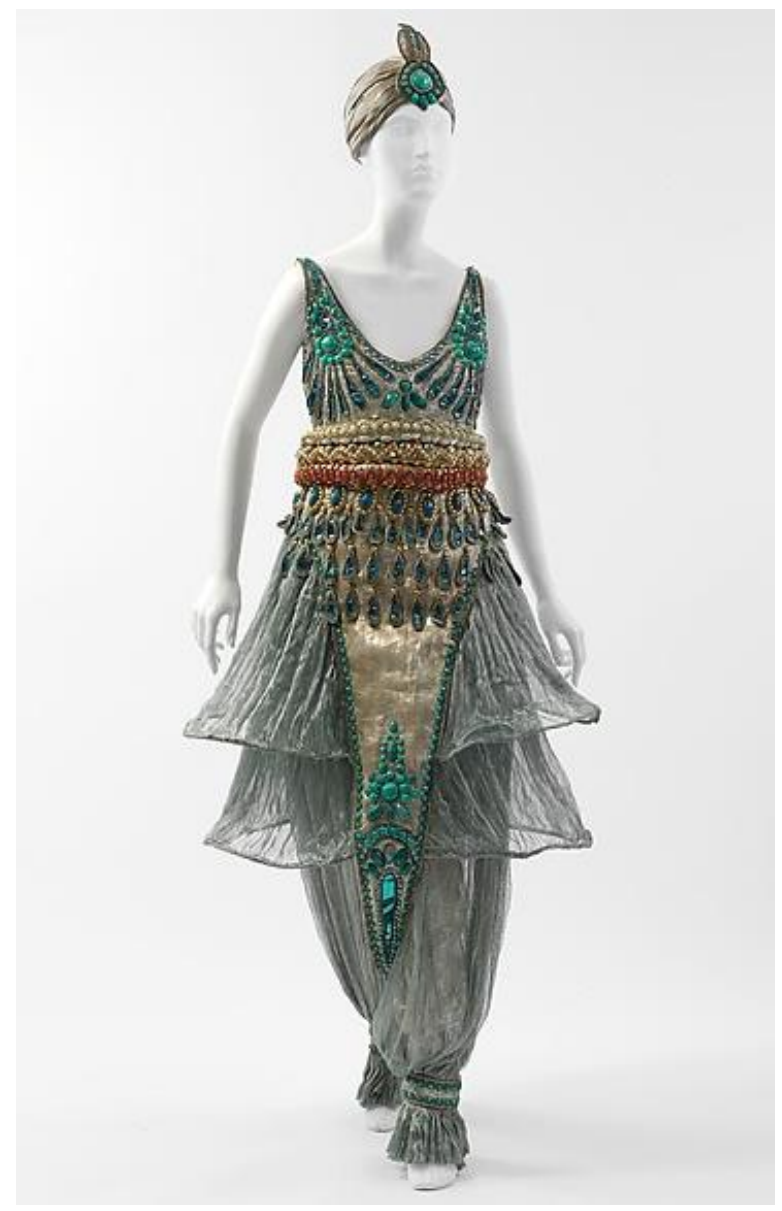

Figure 19.

Paul Poiret, fancy dress costume designed and worn to the mille et deuxième nuit party, 1911, metal, silk, cotton, Length $127.6 \mathrm{~cm}$, diameter $20.6 \mathrm{~cm}$, New York, Metropolitan Museum of Art. 
the trend of innovation and creativity begun by Worth and developed by Poiret in the nineteenth century. ${ }^{195}$ Embroidery came to be an integral part of the now burgeoning industry of luxe, or haute couture. Undertaken at specialist embroidery ateliers, the anonymous workers, les petites mains, did not experience the same financial benefits or public acknowledgement as that of the designers. But without their skills, the designer's dreams could not be realized.

\section{Les Années Folles}

The social setting for these exciting new haute couture designs were the years of Les Années Folles. This period of flamboyant energy followed the horrific, destructive yeas of World War I. They began in 1920 and finished in 1929 with the onset of the Grande Dépression. The arrival of Americans as allies of the war brought the new sound of Jazz to France, together with a previously unseen energy for dance. Josephine Baker embodied everything about the new age. Her sensuous dance routine with La revue Négre electrified Paris. Celebrities were born as radio and cinema became accessible to everyone. Film was inspired by fashion and leading designer Paul Poiret, with previous experience at the Ballets Russes, was asked to design for Broadway shows, and Erté was invited to work at MGM in Hollywood. ${ }^{196}$ Dancing in nightclubs and cabaret became the most popular entertainment and nightclubs such as Le Bøuf sur le toit opened their doors to the flappers of the day. The Charleston, initially considered vulgar, became a dance craze and the "flapper" fashion that accompanied it, accentuated the movement and swing of the body. The flapper dress

\footnotetext{
195 www.vanityfair.com

${ }^{196}$ Virginia Bates, Jazz Age Fashion, Dressed to Kill (Rizzoli International Publications, 2013),12.
} 
with its dropped waist and swinging short skirt became an icon of the era. Heavily beaded and laden with sequins, the dresses were quite heavy, but this did not seem to inhibit the enjoyment of the dancers. The emergence of la garçonne look, with the boyish, bobbed hairstyles and slender silhouette, shocked French society, as did the outrageous behaviour and challenge to conservative social norms that went with it. Women's fashion revealed more flesh than ever before, with no corsetry. The embroidery ateliers loved the new fashion because it meant much more work for them. The Art Deco style had by now super-ceded Art Nouveau and the Art Deco designs were reflected in the design and pattern of the flapper dresses. Hand sewn geometric dresses using Bohemian and French glass beading, sewn on a base fabric of crêpe de chine, were dazzling when the light fell on the faceted, lustre-coated beads and crystals. ${ }^{197}$ Fashion, which had been on hold during the war, was now invested with a new energy.

French women had been liberated by the war. Now used to working in the public domain, in positions and industries that had previously been assigned to men, had liberated them from certain social constraints. More independent, they lounged about in trousers, designed by Chanel, with men's style jackets, smoking freely. Evening jackets on the other hand were made from decadent fabrics such as gold lamé and velvet, and were produced in amazing colours. Lace and embroidery were appliquéd onto the garment and an abundance of crystals and beading were applied. A new fashion item was the opera cape, an elaborate and highly decorated alternative to the theatre coat. Heavily embroidered with sequins and beads, fur and feathers they were

\footnotetext{
${ }^{197}$ Bates, Jazz Age Fashions, 11.
} 
very glamorous. Sequins and beads now even extended to cloche hats, which were designed to complement the whole outfit.

Cocktails were now enjoyed by the party-goers and the accompanying cocktail dress, an essential item in the wardrobe of la garçonne, was often exclusive and individually designed. Much more body was exposed and men were now allowed to see a woman's legs and neck. There was also a trend for back décolleté, diaphanous fabrics and intricate stitching. ${ }^{198}$ The charged atmosphere of dance and entertainment was complimented by the swinging dresses, intricately beaded and adorned with sequins. This was a fashion language of seduction as well as of emancipation and action. Rousseau's very different ideals for men and women were now reconciled in the one daring persona.

\section{Protection of Haute Couture}

In order to protect haute couture and its association with luxury, exclusivity, creativity and, above all, with France, the Chambre de commerce et d'industrie de Paris established the following criteria for membership of the Chambre syndicale de la haute couture in 1945, updating it in 1992. Firstly, a designer must create made-tomeasure clothing for private clients and offer personal fittings. They must also have a full-time workshop in Paris that employs no fewer than twenty staff. Finally, the fashion house must present two collections a year - in January and July - comprising both daytime and formal evening wear. Reminiscent of controls exercised by the historic embroidery guild of the previous centuries, these regulations are designed to

\footnotetext{
${ }^{198}$ Bates, Jazz Age Fashions, 16.
} 
protect the quality and exclusivity of the garments produced by haute couture designers. The challenge that now exists however, is maintaining the number of skilled workers that can provide the necessary handmade parures that are an integral part of the haute couture design. Unfortunately, now the number of skilled workers in France is declining, many orders are being sent to India and China where the work can be undertaken at a cheaper rate, even though the quality of the materials and technical skills can be variable. Most haute couture designers continue to support the Parisian artisans.

Hand embroidery, as an integral part of this story of stitch, has continued to evolve, becoming an essential partner of the high fashion world of haute couture regulated by the Chambre de Commerce. Designers demanding high standards and the use of complex techniques, both old and new, have only been able to call upon a limited number of artisans with the necessary savoir faire to create embroidery for their garments. At the end of World War II there were around forty major embroidery ateliers in Paris. Today only five or six remain. They each possess extensive archives, which they can refer to for inspiration and creativity. The archives are the contemporary equivalent of the samplers of the sixteenth century. By using only the best of materials and craftsmen, and thanks to the control exerted by the Chambre de commerce d'industrie de Paris, the quality of the garment can be assured.

In order to maintain the traditional handcrafts and skills associated with French artisans, the House of Chanel has in the last decade been active in buying ateliers. In 1997 they established a company called Paraffection, which translates as 'for the love of', and acquired ten top ateliers; Lesage, master embroiderers, Barrie, suppliers of Scottish cashmere, Lemarie, plumassiers, Goossens, goldsmiths, Causse, 
glovemakers, Guillet, artificial flower makers, Michel, hatmaker, Massaro, shoemakers, Desrues, costume jewellery and buttons, and Montex, master embroiderers. The Maison de Lesage also now runs an embroidery school so that its highly specialized savoir-faire is not lost. Julie Georgia Bernard's recent documentary Handmade with Love in France, celebrates the Parisian artisans who create fabulous haute couture outfits for the likes of Dior, Chanel and Yves Saint Laurent, using traditional techniques. Her film focuses on the challenges facing four artisans who are each reaching retirement age, who have no successors to take over their workshops.

\section{House of Lesage}

The Maison de Lesage has been a leading atelier for producing embroidery and has formed a true mariage with the designers of haute couture. The studio was founded during the Second Empire by Albert Michonet, who was the embroiderer to Napoleon III. Michonet also produced embroideries for Charles Worth. Albert and his wife Marie-Louise Favot then bought the studio from Michonet, a few years before their son François François Lesage was born on March 31, 1929, "into a pile of beads and sequins."199

\footnotetext{
${ }^{199} \mathrm{http} / / /$ www.nytimes.com/2011/12/02/style/francois-lesage-dies-at-82-led-couture-embroideryatelier.html?_r=0. It was almost predetermined that François would follow his father's footstep into the world of embroidery. François gained much experience in Hollywood selling Lesage embroidery to movie stars and costume designers, and was content to return to the studio in Paris upon the death of his father in 1949.
} 
Marie-Louise had originally been a young designer at the House of Vionnet and the studio was well supported with work from this young designer who considered the family as friends. They soon established an outstanding reputation with their high quality work and Paul Poiret, Jeanne Paquin, and Elsa Schiaparelli began to use their talents. Each of these designers included embroidery in their original design process so that it became part of the artistic whole, rather than something that was applied later as an afterthought.

An example of the innovation and creativity needed to represent the ideas of designers is evident in the response of Albert Lesage to Vionnet's designs. He perfected the adaptation of embroidery and developed new techniques in order to accommodate Vionnet's new bias cut, a whole new challenge considering embroidery has to be executed flat. A two-dimensional fabric with its motif changes into a threedimensional object when worn. To create the effect of lightness Lesage searched for techniques associated with painting by using colour techniques that used vapourisation on the reverse side of a fabric. ${ }^{200}$ During the years of the Années Folles, Albert created over 1500 pieces of embroidery for Vionnet. Some of his new techniques, stimulated by Vionnet's desire for innovation and perfection were more successful than others. The squeezing of glass beads to give them a subtle variety was very successful, but the use of beef gelatin, bought from the butchers of Les Halles to make sequins, would prove to be a mistake. He laid the sequins one over the other, producing a fish scale effect, which was very attractive. However, the sequins had to be abandoned following a call in the middle of the night from a very unhappy

\footnotetext{
${ }^{200}$ White, Haute couture Embroidery: the Art of Lesage, 48.
} 
customer whose evening gown had melted in the heat of the Paris Opéra, leaving her drenched in consommé. ${ }^{201}$

One of the key problems when applying beading to a garment was the weight. The beading of the fabric can affect the drape of the fabric and may exaggerate any stretch the fabric might have. The weight of the beads may also distort the weave of the fabric or tear the fabric if too great. When working with woven fabrics, areas that hang on the bias will stretch more than adjacent areas, while knits stretch much more in the horizontal direction than in the vertical direction. ${ }^{202}$ Vionnet's designs that called for beading and bias cuts, were especially challenging but were exciting for women who wanted a new freedom in their clothing. Vionnet's vision of the female form revolutionized modern clothing. As Kamitsis suggests:

(Vionnet) found in the house of Lesage an attentive partner who followed her principles to the letter, inventing appropriate techniques for each individual garment. For example, in order not to work against the bias cut, Lesage invented the technique of the vermicelli droit fil or carré, an adaptation of the Lunéville method of embroidery; every stitch was treated either in the direction of the warp, or in that of the weft, so as not to hinder the natural way in which the fabric hung. ${ }^{203}$

${ }^{201}$ Ibid., 51.

$202 \mathrm{http} / / /$ costumedesignersguild.com/articles-videos/articles-archive/beading/

${ }^{203}$ Madeleine Delpierre, The Master touch of Lesage, 10. 
Other embroiderers of the early twentieth century included Matti, who embroidered the famous "Byzantine gown" ordered in 1904 by Countess Greffulhe for her daughter's marriage and Rebé, who in a career spanning 50 years collaborated with all the great couturiers and reached his apogee with Dior. Each identified with the spirit of the gowns they were asked to adorn. ${ }^{204}$ These individuals stood out from amongst their peers, displaying a unique sensitivity to the artistic vision of the couturiers.

François Lesage took over the atelier when his father died in 1949. As talented as Albert, he was guided to success by his mother. Throughout his life, Lesage stuck to one golden rule; he refused commissions unless he could meet the client face to face. "I have to see the designer, the sparkle in the eyes," he explained, "I have to undress the mind." 205 As a general rule, designers supplied François Lesage with their inspiration or theme, and he would then design up to one hundred ideas as he sought to translate the idea into a reality. Of these the designer would pick three they liked and then Lesage would guide his petites mains to stitch samples for further presentation to the designer. Sometimes the designer would not bring a drawing of ideas, but would present a phrase, a feeling, an image or an inspiration for Lesage to work with. From this initial meeting a design would be drawn, discussed again and then embroidered samples made to try and achieve the effect the designer wanted. In effect, Lesage was a translator and facilitator of communication from the ideas/ message that the designer wanted to impart. He enhanced the concept through the use

\footnotetext{
${ }^{204}$ Ibid.

${ }^{205} \mathrm{http}: / /$ www.independent.co.uk/news/obituaries/franois-lesage-doyen-of-french-haute-coutureembroidery-6275576.html
} 
of embroidery and sequins. Lesage explained, "We are given a sketch and it is our job to interpret it. The couturier is the architect and we are the decorators. It's a

collaborative effort." ${ }^{206}$ Lesage admitted that he himself could not stitch and yet his name is credited with many of the beautiful haute couture embroideries. While he worked together with the fashion designer to interpret the designs it was his ouvrières that provided the samples and the completed works. Lesage was often heard to repeat, that "sans ses filles, ses brodeuses, il n'est rien." He also admitted not even being able to sew on a button. ${ }^{207}$

\section{Embroidery and Fashion as Art}

In the twentieth century, many French artists used the medium of embroidery to identify themselves as artists, thus encouraging a revival of interest in the medium. Sonia Delaunay and Schiaparelli both incorporated embroidery into their work not as an aesthetic or even as a functional component but as a symbol of their identity as artists.

Delaunay aspired to be a 'modern' woman, and so both an independent businesswoman and an artist, who used an exotic or oriental accent in her visual language. Parker suggests that it was Delaunay's background in applied arts, in particular embroidery that led her towards abstraction in her art, and the decision to work nonfiguratively with colour. ${ }^{208}$ This was achieved through her use of traditional peasant patterns, colours and embroidery techniques gleaned from her own cultural heritage

\footnotetext{
${ }^{206}$ Farnault, Haute Couture Ateliers, 101.

${ }^{207}$ http://www.vmfpatrimoine.org/wp-content/uploads/2011/02/Rapport_C_DUMAS_-metiers-dart2009.pdf (acessed 5 February, 2015).

${ }^{208}$ Parker, The Subversive Stitch, 192.
} 
of the Ukraine and Russia. She was committed to exposing as many people as possible to artistic ideas and so designed everyday objects such as lampshades, scarves, ballet costumes, embroidered waistcoats and coats. Her best work was completed in the early twentieth century. ${ }^{209}$

Schiaparelli, for her part, was influenced by the Surrealist art movement, which inspired her to envisage daring new uses for embroidery, which embodied the notions of fantasy and dreams. The aesthetic narratives of Delaunay and Schiaparelli as told through the artistic medium of embroidery were thus closely linked with the notion individual rather than collective identity.

Schiaparelli who used embroidery to express artistic ideas, is arguably the doyenne of designer broderies, whose embroidery was always integral to her designs. She knew she could rely on the talents of Albert Lesage to design and produce for her the effects that she wanted. Schiaparelli saw working in collaboration with other artists and artisans as the means of producing a greater work of art than was possible if she worked alone. By 1934, following years of economic depression, women were keen to break free of the prevailing gloom. They wanted to feel the excitement that they had tasted in the twenties and Schiaparelli's designs gave them the opportunity to be “defensive by day and aggressively seductive" by night. ${ }^{210}$ Her designs challenged male dominance and gave women confidence. This was as important as the glitter and fun of her designs, which resonated with women's growing desire for liberation.

${ }^{209}$ Ibid.. Parker research points out that far from bringing art to a wider public Delaunay's work was ultimately appropriated by the world of Parisian haute couture.

${ }^{210}$ White, Haute couture Embroidery: the Art of Lesage, 59. 
Schiaparelli worked within the framework of surrealism, avant-gardism, and modernism. Originally Italian, she moved to Paris in 1922, following a number of Surrealist friends. In 1937 she invited the artist Cocteau to work with her and to give her a design for one of her pieces. One of her most famous pieces, a long evening coat with the key design on the back, featured a design from an original drawing by Cocteau of two women facing each other symmetrically, their profiles forming the contours of a vase full of roses. The huge success of this design was because of the collaboration of three talents, Schiaparelli, Cocteau, and Lesage, who implemented the design with hand embroidery of the highest quality and most inspired creative interpretation (See fig. 20). 


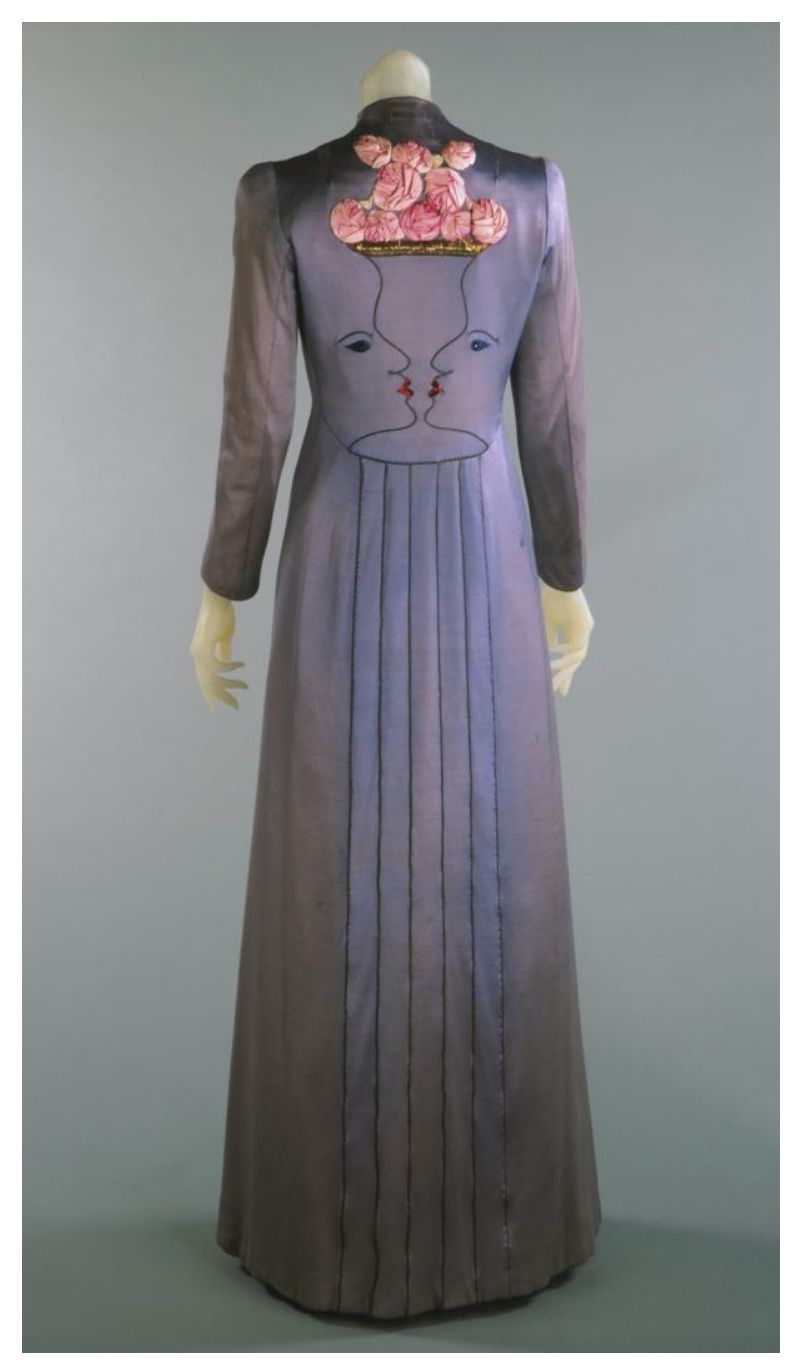

Figure 20.

Women's Evening Coat, designed by Elsa Schiaparelli. Designed in collaboration with Jean Cocteau. Embroidered by Lesage, Paris. French, Fall 1937 Rayon knit, silk and gilded metallic thread embroidery, silk appliquéd flowers. Centre Back Length: $147.3 \mathrm{~cm}$ Philadelphia Museum of Art: Gift of Mme Elsa Schiaparelli, 1969. 
Many of Schiaparelli's designs were consciously worked so as to exhibit the embroidery itself. Her Apollo cape referenced the magnificence and power of the court of Louis XIV with its rendition of Versailles' Apollo fountain. Another collaboration with Cocteau and Lesage produced a jacket with a woman's profile looking upwards, with a mane of golden hair flowing down one sleeve. At waist level there is a hand, a favourite Surrealist motif, holding a scarf, which in this case Lesage decided to embroider in cellophane. (See Fig. 21). The interpretation of the design, the single line contour, the different nuances of the hair as it falls down the arm are all complimentary. Schiaparelli decided to make this jacket out of coarse linen rather than a more sophisticated fabric, challenging previous associations and connotations. The onlooker was challenged to interpret a surrealist message rather than an aesthetic image. But they were also invited to 'unlearn' the conventional view that embroidery was a means of embellishing an already rich and costly fabric. This was embroidery as art, on fabric used like a canvas. 


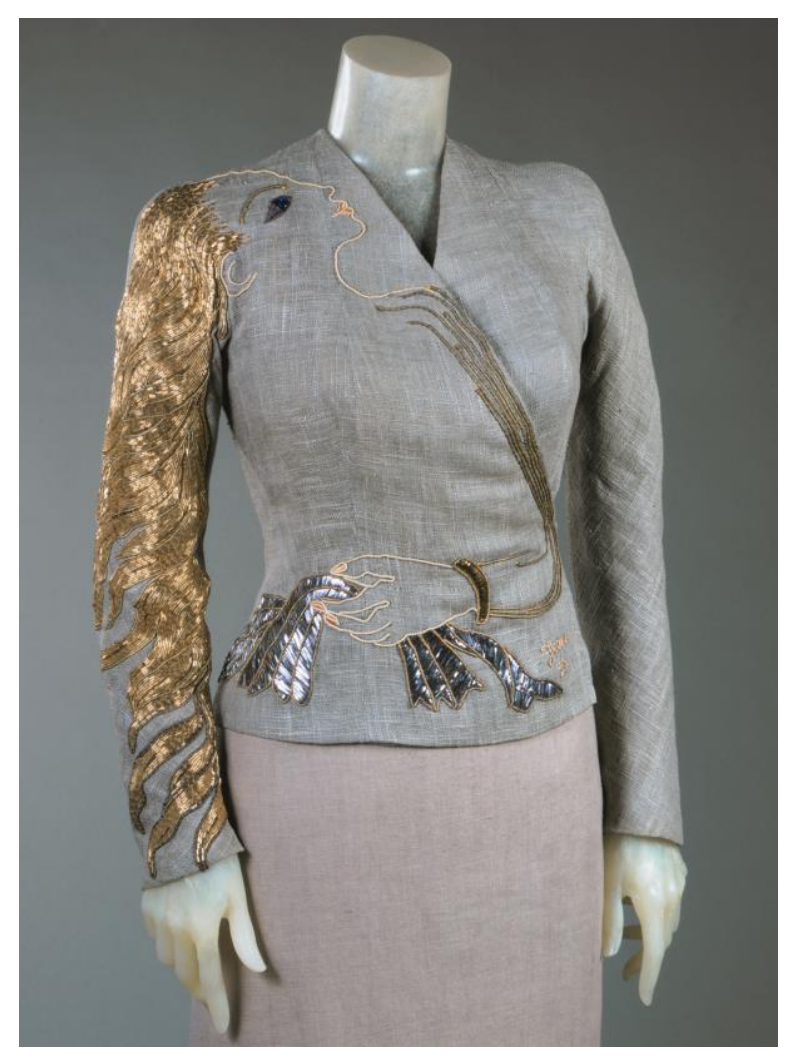

Figure 21.

Woman's Dinner Jacket. Designed by Elsa Schiaparelli, Designed in collaboration with Jean Cocteau, Embroidered by Lesage, Paris, Fall 1937. Linen plain weave, gilded metallic and silk thread embroidery, beads, and paillettes. Waist: $71.8 \mathrm{~cm}$. Center Back Length: $52.7 \mathrm{~cm}$. Circumference (Bust): 87.6 cm. Hips: 90.2 cm. Philadelphia Museum of Art: Gift of Mme. Elsa Schiaparelli, 1969.

The embroidery was thus the product of an on-going artistic conversation between the designer and the embroiderer. Schiaparelli pushed the embroidery skills of the House of Lesage as far as she could. She also epitomised the expression of excess now associated with couture, through her use of embroidery. With war on the horizon, she reached her apogee with four spectacular shows in one year; the amazing Circus themed show in February, with performing animals and acrobats. Corresponding embroidery designs included the Ringmaster, the Fat Lady and the Skeleton man. The Pagan collection followed in April, the Astrology collection in August and the Commedia dell'arte collection in October. ${ }^{211}$ Each of these was a spectacular show in

\footnotetext{
${ }^{211}$ White, Haute couture Embroidery: the Art of Lesage, 66.
} 
its own right. The culture of the spectacle associated with Louis XIV was thus briefly revived in the work of this creative woman.

The Nazi occupation of France in 1940 devastated the fashion industry. The Germans were determined to take the industry to Berlin and Vienna but Lucien Leleong, President of the Chambre Syndicale ${ }^{212}$ resisted and it never happened. ${ }^{213}$ Throughout the occupation the fashion industry survived thanks to sales to rich German officers wives, collaborators and nouveaux riches. Following the war, tastes had changed. Dior showed his first collection in 1947 and it was seen as bringing a much needed freshness and class to a demoralized France. Dior used the embroiderer Rebé, but his designs were not as innovative as those of the House of Lesage. Dior also expanded his range of goods into many other areas such as cosmetics and this added diversification ensured a huge financial success. A post-war economic euphoria helped buoy the fashion industry. François Lesage returned from America following the death of his father.

In the decades following the war, Lesage worked with designers such as Yves Saint Laurent who translated Van Gogh's Irises into a famous iridescent jacket, with Givenchy, Calvin Klein and Oscar de la Renta. With 60,000 samples accumulated over its long history, the House of Lesage archives now represent the largest collection of couture embroidery in the world, with the atelier adding to this rich

\footnotetext{
212 This is the regulating commission that determines which fashion houses are eligible to be true haute couture houses.

${ }^{213}$ White, Haute couture Embroidery: the Art of Lesage, 75.
} 
heritage every year with around a hundred new embroidery design samplers. ${ }^{214}$ "Our job is to give intellectual and creative food to the couturier. Though the archives are a source of inspiration, we always create a new sample for the designer," explains Barrère, the new Artistic Director since the death of François in 2011. A designer will usually come to the atelier with an idea or a general theme, which then needs to be "translated and refined." ${ }^{215}$ This is where the archives come into play.

Haute couture is now justly famous for its dazzling and shimmering embroidery, which uses sequins, metallic threads, beads, and as time progressed, materials not previously considered for embroidery, like plastic and shells. Because each sequin is individually hand placed and sewn, and because the innumerable stitches required are time consuming, the process for constructing a couture jacket can often take up to 100 hours and may cost up to $\$ 120,000$. "Our role is to be chameleons... we receive a sketch and it is up to us to interpret. The couturier is the architect, we are the decorators" said Francois Lesage, talking about the process of creating haute couture. $^{216}$

From a peak of two hundred designers before World War II, only eleven authentic haute couturiers remained in 2009. The decline in haute couture, largely because of the expense of producing it and the limited number of clientele, has now become a concern. However, while the dresses themselves are produced at a loss the marketing exposure that the runway shows give to the companies, highlights the many other

\footnotetext{
${ }^{214}$ http://couturenotebook.com/2012/11/17/maison-lesage-atelier/ (accessed 3 February, 2015).

${ }^{215}$ Ibid.

${ }^{216}$ http://notordinaryfashion.tumblr.com/What\%20is20Haute\%20Couture (accessed 3 February, 2015).
} 
more profitable products that fashion houses produce, e.g. prêt-à-porter clothing, perfumes and accessories. The yearly couture shows are spectacular events and they showcase the strength of design and technical ability that haute couture demands. Similar to the theatrical spectacles of the court of Louis XIV, the language of sensational opulence remains the same using the same vehicle of communication of embroidery and other artisanal effects. With increasing communication technologies such as Facebook, blogs and Twitter, the ability for the collections to influence fashion are huge and instant. The new clientele, often from Russia, China and the Middle East, are rich and technology savvy. The average age of House of Dior clients has changed from forty years of age to thirty years. The clothes are so expensive that they are only bought by a limited number of women, around four hundred. However, the designers all agree that it is the message of these displays of opulence and excess that makes them relevant to fashion today - a message of fantasy, dream worlds and perfection in a pragmatic world, where much of what we wear reflects a more mundane and mechanized reality. The skills of the embroiderer can never be fully mechanized and the results are far from mundane. And this is why, as Karl Lagerfield has proclaimed:

“Je ne conçois pas de mode sans broderie." 217

\footnotetext{
${ }^{217}$ Karl Lagerfield, http://www.lexpress.fr/styles/mode/le-maitre-brodeur-francois-lesage-est mort_1056987.html (accessed 23 January, 2015).
} 


\section{Chapter Seven: Conclusion}

The contemporary view of the creation of embroidery and lace tends to be informed by stereotypical notions of 'arsenic and old lace', by the cosy domesticity of the cross-stitch sampler, and the traditional, largely conservative, rituals implicit in the fabrication of wedding dresses and mourning veils. Furthermore, the works that a needle can create have tended to be dismissed as 'women's' work, thanks to the highly gendered view of thread work introduced by Rousseau in the eighteenth century. In France, however, haute couture since the early twentieth century has provided a vehicle for the creative language of embroidery to be used in new ways as a language of fantasy and escapism. In recent decades, the declining haute couture markets threatens the existence of this handwork also, which means that a rich medium of visual rhetoric, often considered an integral part of the industry of luxe in France will be lost.

Embroidery and lace are two of the most significant embodiments of vestimentary discourse, and the changing language of both messaging and reception of the language of thread work grants insights into cultural, social and political change.

From the seventeenth century, professional embroiderers and lace makers worked from patterns inspired by both fashion trends and by prevalent beliefs and values in the society of the time. With no accompanying verbal text, the embroiderers had to be highly skilled in their ability to interpret the designs in their own creative style. Such a skill, as we have seen, was learned by male embroiderers through long apprenticeships and directed assignments, as well as by more subordinate groups of women not initially permitted to work independently - the story of thread work, in 
this regard, has always been 'gendered' in one way or another. This, too, is a reflection of socio-cultural realities.

At the same time, as we have seen, thread work has the capacity to be both intensely personalized and frustratingly anonymous. In practice, what threads to use, the colour, stitches, and effects created were choices often made by the individual embroiderer. Museum curator Jane Schneider has observed that material objects thus created generally "encode the names, biographies, memories and histories of past owners deepening their significance." 218 However, anonymity in the production of thread work in previous centuries makes it difficult to assume the full and complete intention of the piece.

At the court of Louis XIV, a major reference point in this study, embroidery and lace was opulently displayed on costume, which courtiers were compelled to wear. In this way Louis was able to send a clear message of power and to maintain class structures through carefully regulated codes of visual identification. Such clearly codified class structures were less evident after the fall of the ancien régime and the democratization of lace and embroidery. The rise of republican values and the end of aristocratic patronage simultaneously reduced both the value and ideological significance of thread work.

Since the early twentieth century, the fashion industry has replaced the royal courts as a major influence. Ironically, however, anonymity in production still characterizes contemporary haute couture, where les petites mains, or embroiderers, remain hidden

${ }^{218}$ Jane Schneider, "Cloth and Clothing," in Handbook of Material Culture, eds. Chrostopher Tilley, Webb Keane, Susanne Külcher, Michael Rowlands, and Patricia Spyer, 203-20 (London:Sage, 2006), 204. 
in the atelier in the same way as historical professional workers were out of view and unrecognised. The embroidery of an haute couture garment, which may cost hundreds of thousands of dollars, is simply credited to the designer. Or the embroidery is attributed to the head or Maître of the atelier, for example, such as Lesage, who himself admitted to not being able to sew a stitch.

The world of haute couture also bears comparison with the tightly controlled embroidery guilds in several ways. A strict criterion for inclusion as a couturier guarantees the quality of the work and the rules are overseen by a government institution, licences being awarded annually - as was the case when Colbert sought to regulate the lace manufacture in seventeenth century France. Like the guild system for embroiderers, haute couture is systematically organised as a hierarchical system of designers and workers. Examining the ateliers of an array of houses for Vogue in 2008, Hamish Bowles wrote:

Traditionally, in the hierarchy of the haute couture workrooms, with its courtesy titles and unquestioning respect for the designer king, the premières (heads) are responsible for a single workroom, where they specialize in either flou (soft dressmaking) or tailleur (tailoring). "The people who work with chiffon can't work with tweed," says Chanel's head tailor, Jacqueline Mercier, firmly. "It's a question of sensibility." Head dressmaker Cécile Ouvrard (who trained at Christian Lacroix with her mother, Janine Ouvrard) agrees: "Each worker has a different hand, like 
artists. There are girls who are better with chiffon, others with velvet, others lace. $^{219}$

His reference to the 'designer king' and 'girls' indicates that the hierarchical system remains in place, and the attribution of needlework to females and design to males perpetuates the association of thread work as a feminine activity, where women's work is less valued than the creative activities of the Maître.

The language of power in the courts of Louis XIV and Louis XV, where embroidery and lace were signifiers of wealth and status, is reiterated in the world of haute couture. With only a handful of ateliers supplying hand embroidery to the couturiers, whose numbers are now below twenty, garments remain expensive and are thus only bought by an elite. No longer speaking the language of political power an haute couture garment still announces wealth and the contemporary status of the 'celebrity', whose attendance at haute couture shows is considered as essential as was the attendance of the nobility at court. Providing lavish entertainment and showcasing the high quality wearable art that form the 'collections', particularly that of evening wear categories, the language of showmanship and escapism, the unbridled pleasure of the text, is dominant.

Aside from haute couture, embroidery and lace remain an embodiment of personal identity and community identity in regional areas, where the few remaining artisans are committed to retaining traditional techniques and cultural assets. The shaping of regional identity by the use of embroidery and lace in traditional costume can be considered a form of epideictic rhetoric, a rhetoric that can help stimulate engagement 
in local cultural values and practices. Community ties and friendships were found to be enhanced by the praxis of thread work. As Marcus writes, "history is preserved not in the art object, but in the tradition of making the art object." ${ }^{220}$ It is therefore important that extant lace and embroidery is not only displayed in museums and in traditional costume but that the actual methods of its production are preserved, protected and practiced.

The language of lace and embroidery remains a significant form of communication and of meaning making. ${ }^{221}$ The part played by hand-made techniques in disseminating this visual rhetoric is diminishing. Nevertheless, thread work creators and textile artists continue to strive for recognition and appreciation of their works as an art form and as meaningful forms of communication rather than simply folksy or genteel pastimes. Changing public perceptions in this respect is an ongoing challenge for meaning-makers in the world of thread work today.

${ }^{220}$ Jane Marcus, "Still Practice, A/Wrested Alphabet: Toward a Feminist Aesthetic" in Feminist Issues in Literary Sholarship (Indianan: Indiana University Press, 1987), 84.

${ }^{221}$ Maureen Daly Goggin, “An Essamplaire Essai on the Rhetoricity of Needlework Sampler-Making: A Contribution to Theorizing and Historicizing Rhetorical praxis, "Rhetoric Review 21 (2002): 309-38, 312. 


\section{Bibliography}

https://archive.org/stream/dramaticworksofm02moliiala\#page/12/mode/2up (accessed 31 January, 2015).

Barthes, Roland. The Fashion System. California: University of California Press, 1990.

— The Language of Fashion. Translated by Andy Stafford. France: Éditions du Seuil, 1973.

__ Le Plaisir du Texte. Paris: Éditions du Seuil, 1973.

— Mythologies. Paris: Éditions du Seuil, 1957.

Bates, J. Jazz Age Fashion, Dressed to Kill. Rizzoli International Publications, 2013.

Blum, Dilys. Elsa Schiaparelli. Philadelphia: Department of Publishing, Philadelphia Museum of Art, 2003.

Bibliothèque Nationale (BN), Manuscrits Français 21788, (344).

BN, Manuscrits Français 16744, fol. 239.

Bruslons, Jacques Savary des, Dictionnaire universel de commerce, 3 vols., Paris: Veuve Estienne, 1741.

Bury-Palliser, History of Lace. New York: Dover Publications, 1984.

Cario, Hélène and Viviane Hélias. Broderies en Bretagne. Coop Breizh, 2007.

— Dentelles en Bretagne, Coop Breizh, 2008.

http://costumedesignersguild.com/articles-video/articles-archive/beading/

http://couturenotebook.com/2012/11/17/maison-lesage-atelier/ (accessed 3 February, 2015). 
Craik, Jennifer. The Face of Fashion. London: Routledge, 1994.

http://www.christies.com/lotfinder/paintings/jean-baptiste-simeon-chardin-theembroiderer-5649665-details.aspx (accessed 5 December, 2014).

Crowston, C.H. Fabricating Women. The Seamstresses of Old Regime France, 16751791. Durham: Duke University Press, 2001.

_ "Women, Gender and Guilds in Early Modern Europe," presented at the conference Return of the Guilds, Utrecht University, Utrecht, 5-7 ${ }^{\text {th }}$ October, 2006.

de Bonneville, Françoise. The Book of Fine Linen. Paris: Flammarion, 2011.

de Laprade, Laurence. Le Poinct de France et les centres dentelliers au XVII et XVIII siècle. Paris: Laveur, 1905.

de Marley, Diana. Louis XIV and Versailles. Costumes and Civilization. New York: Holmes and Meier, 1987.

de Motteville, Françoise Bertaud. Madame de Motteville, Mémoires sur Anne d'Autriche et sa cour, Edition M-F. Riaux, vol. IV, Paris: Charpentier, 1855.

de Planhol, Xavier. A Historical Geography of France. Cambridge: Cambridge University Press, 1994.

de Rouvray, Louis Duc de Saint Simon Vermandois. Mémoires, A. de Boislisle, (ed.) 43 vols, 1879-1930.

Delpierres, Madeleine G. L'Histoire du point d'Alençon. Paris: Renouard, 1886.

—_Dentelles et Broderies dans la Mode Française du XVIe au XXe siécle. Musée du Costume de la Ville de Paris, 1964.

— Se vetîr au XXVIIIe siécle, USA: Biro, 1996. 
Diderot, Denis, Jean Le Rond Alembert and Pierre Mouchon. Encyclopédie: ou, Dictionnaire raisonné des sciences, des arts et des métiers, 1751-1772. Genève: Pellet, 1777.

Diderot, Denis and Jean le Rond d'Alembert Encyclopédie, ou dictionnaire raisonné des sciences, des arts et des métiers, etc., eds.. University of Chicago: ARTFL Encyclopédie Project (Spring, 2013 Edition), Robert Morrissey (ed), http://encyclopedie.uchicago.edu/

Dixon, E. "Craftswomen in the livre des Métiers.” The Economic Journal 5, no. 18 (1895): 209-28.

Dock, S. V. Costume and Fashion in the Plays of Jean-Baptiste Poquelin Molière: a Seventeenth Century Perspective. Genève: Éditions Slatkine, 1992.

Donaldson-Evans, Mary. "Pricking the Male Ego: Pins and Needles in Flaubert, Maupassant, and Zola." Nineteenth-Century French Studies, vol. 30, no. 3\&4, Spring-Summer 2002: 254.

Duplessis, Georges. "Lace-Work." The Connoisseur 1, 4 (1887): 3-13.

Earnshaw, P. The Identification of Lace, UK: Shire Publications, 2000.

L Lace in Fashion: From the Sixteenth to the Twentieth Century. London: Batsford, 1986.

http://www.lexpress.fr/styles/mode/le-maitre-brodeur-francois-lesage-est mort_1056987.html (accessed 23 January, 2015).

Farnault, Hélène. Haute Couture Ateliers. London: Thames and Hudson, 2014.

Fayolle, R. La Mode en France 1715-1815. Paris: La Bibliothèque des Arts, 1990. 
Fitzsimmons, Michael. From Artisan to Worker: Guilds, the French State, and the Organization of Labour, 1776-1821. New York: Cambridge University Press, 2010.

Foss, Sonja K. “Theory of Visual Rhetoric.” In Handbook of Visual Communication: Theory, Methods, and Media. Ed. Ken Smith, Sandra Moriarty, Gretchen Barbatsis, and Keith Kenney. Mahwah, New Jersey: Lawrence Erlbaum, 2005, $141-52$.

Flaubert, Gustave. Madame Bovary. Paris: Éditions Gallimard (1857), 2001.

http://gallica.bnf.fr/ark:/12148/bpt6k134040c.r=Louis+XIV+1660.langE (Accessed 23 October, 2014).

Gibson, Wendy. Women in $17^{\text {th }}$ Century France. London: McMillan Press, 1989.

Godineau, Dominique. The Women of Paris and their French Revolution. Berkley: University of California Press, 1998.

Goggin, Maureen Daly. "Visual Rhetoric in Pens of Steel and Ink of Silk: Challenging the Great Visual/Verbal Divide," in Defining Visual Rhetorics, ed. Charles Hill and Marguerite Helmers (London: Lawrence Erlbaum Associates, 2004), 87-110.

_ "An Essamplaire Essai on the Rhetoricity of Needlework Sampler-Making: A Contribution to Theorizing and Historicizing Rhetorical Praxis." Rhetoric Review 21 (2002): 309-38, 312.

Gundle, Stephen. Glamour. Oxford: Oxford University Press, 2008.

Hamerton, Katharine, J. “Rousseau and the New Domestic Art of Women's Taste." In Proceedings of the Western Society for French History. Columbia College, 2009.

http://www.independent.co.uk/news/obituaries/franois-lesage-doyen-of-french-hautecouture-embroidery-6275576.html (accessed on 12 December, 2014). 
Isambert and Taillander. Recueil général des anciennes lois françaises: depuis l'an 420 jusqu'à la révolution de 1789, vol. XVI, Paris: Belin-Leprieur, 1829. https://archive.org/details/recueilgnraldes03jourgoog (accessed 20 November 2014).

Jones, J. "Repackaging Rousseau: Femininity and Fahion in Old Regime France." French Historical Studies 18, no. 4, Autumn, 1994: 939-67.

Kraatz, Anne. Dentelles. Paris: Éditions Adam Biro, 1988.

_ Lace: History and Fashion. Pat Earnshaw (trans.) New York: Rizzoli International Publications, 1989.

— "The Elegant Art of Dress," in An Elegant Art: Fashion and Fantasy in the Eighteenth Century, Phil Freshman, (ed.) 107-124, New York, Harry N. Abrams, Inc., 1983.

Lacroix, Paul, XVIIIe siècle:institutions, usages et costumes, Firmin-Didot, 1875.

La Révolte des Passemens, Paris: Charles Sercy, 1661. https://www.cs.arizona.edu/patterns/weaving/articles/nb30_pnt.pdf. (accessed 3 March, 2015).

Lefébure, Ernest. Broderie et Dentelles. Paris: Quantin, 1887.

_L Les Points de France, Translated by Margaret Taylor Johnstone, New York: Riverside Press, 1912.

Lespinasse, René. Les Métiers et Corporations de la Ville de Paris XIV-XVIIIe Siècle: Histoire Générale de Paris, 1886-97, vol. 2.

Levey, Santina. Lace, A History. London: Victoria and Albert Museum, 1983.

Locatelli, S. Voyage en France. Paris: Vautier, 1905. 
Maeder, Edward. An Elegant Art: Fashion and Fantasy in the eighteenth century from Los Angeles County Museum of Art collection of costumes and textiles. Los Angeles: Los Angeles County Museum of Art in Association with Harry N. Abrams Inc., 1983.

Marcus, Jane. "Still Practice, A/Wrested Alphabet: Toward a Feminist Aesthetic" in Feminist Issues in Literary Sholarship, 79- 97, Indiana: Indiana University Press, 1987.

Mansel, Philip. Dressed to Rule, Royal and Court Costume from Louis XIV to Elizabeth II. Connecticut: Yale University Press, 2005.

Melton, James. The Rise of the Public in the Enlightenment. Cambridge: Cambridge University Press, 2012.

Menteges, Gabriele. http://www.ieg-ego.eu/en/threads/models-and-stereotypes/thespanish-century/gabriele-mentges-european-fashion-1450-1950 (accessed 28th January, 2015).

http://www.metmuseum.org/exhibitions/listings/2007/poiret/the-thousand-andsecond-night (accessed 23 January, 2015).

Molière, Jean-Baptiste. L'Ecole des Maris, Act 2, Scene 6. http://www.toutmoliere.net/acte-2,405409.html\#acte_ii_scene_premiere (accessed 20 February, 2015).

— L'Ecole des Maris, Act 1, Scene 2. http://toutmoliere.net/acte-1,405408.html (accessed 20 February 2015).

Moyer, Johanna B. "Sumptuary law in ancien régime France, 1229-1806." PhD diss., Syraceuse University, 1997.

http://surface.syr.edu/hst_etd/ (accessed 24 November 2015). 
Nantes, Musée des Beaux-Arts, and Toulouse, Musée des Augustins. Visages du grand Siecle: le portrait francais sous le regne de Louis XIV, 1660-1715. Nantes: Somogy, 1997.

http://notordinaryfashion.tumblr.com/What\%20is20Haute\%20Couture (accessed 3 February, 2015).

http://www.nytimes.com/2011/12/02/style/francois-lesage-dies-at-82-led-coutureembroidery-atelier.html?_r=0

Parker, Rozsika. The Subversive Stitch: Embroidery and the Making of the Feminine. London: I.B. Tauris \& Co Ltd, 2012

Payen-Appenzeller, Pascal. La Broderie. Paris: Armand Colin, 1994.

Preston, Jesse and Ryan Ritter. "Cleanliness and Godliness: Mutual Association between two kinds of Personal Purity," Journal of Experimental Social Psychology 48, (2012), 1365-1368.

Project Gutenberg Ebook, Chats on Old Lace and Needlework, (2008), http://www.gutenberg.org/files/26120/26120-h/26120-h.htm. (accessed 24 November, 2014).

Proust, Marcel Du côté de chez Swann.

http://ebooks.adelaide.edu.au/p/proust/marcel/p96d/chapter2.html (accessed 28 January 2015).

Reynolds, Anna. In Fine Style. London: Royal Collection Trust, 2013.

Ribeiro, A. Dress in Eighteenth-Century Europe 1715-1789. Yale: Yale University Press, 2002.

—_Dress and Morality. Oxford: Berg, 2003. 
— The Art of Dress: Fashion in England and France 1750-1820. Yale: Yale University, 1995.

Richelieu, Armand Jean du Plessis, Cardinal, duc de. The Political Testament of Cardinal Richlieu, translated by H.B. Hill, University of Winsconsin Press, 2003.

Roche, Daniel. France in the Enlightenment. Translated by Arthur Goldhammer. London: Havard University Press, 1998.

_ L La Culture des Apparences. Translated by Jean Birrell. Paris: Libraire Arthème Fayard, 1989.

— Revolutionary Appearance or the Revolution of Appearances. http://www.library.vanderbilt.edu/Quaderno/Quaderno2/Q2.C8.Roche.pdf. (accessed 23 December 2015).

Rousseau, Jean-Jacques. Emile ou l'éducation. Translated by Allan Bloom. Basic Books, 1979.

— Considérations sur le Gouvernement de Pologne, Geneve, 1772.

Saint-Aubin, C.G. de. L'Art du Brodeur. Paris: De L'Imprimerie de L.F. Delatour, 1770.

Savary des Bruslons, Jacques. Dictionnaire universel de commerce, 3 vols (Paris: Veuve Estienne, 1741).

Scarpa, Marie. L'éternelle jeune fille: une ethnocritque du 'Rêve' de Zola. Paris: Éditions Champion, 2009.

Sheridan, Geraldine. "Views of Women at Work by the Royal Academicians: The Collective Descriptions des Arts et Metiers (1761-1789)." Studies in EighteenthCentury Culture. vol. 32, 2003, 155-191. Access provided by Victoria University of Wellington, 25 Aug 2014. 
Standen, Edith A. "The Grandeur of Lace." The Metropolitan Museum of Art Bulletin 16, 5 (1958): 156-62.

Steele, Valerie. Paris Fashion: A Cultural History. Oxford: Oxford University Press, 1988.

Synge, Lanto. Art of Embroidery. Woodbridge: Antique Collector's Club, 2001.

Tobin, Maureen Daly Goggin and Beth Fowkes, (eds.) Women and the Material Culture of Needlework and Textiles, 1750-1950. Surrey: Ashgate Publishing Limited, 1997.

http://www.thefashionlaw.com/is-givenchy-really-a-couture-house/ (accessed 28 March 2015)

Trouille, Mary Seidman. Sexual Politics in the Enlightenment. New York: State University of New York Press, 1997.

Vanity Fair, Toujours Couture, www.vanityfair.com/style/features/2009/09/couture200909 (accessed 26 January, 2015).

http://www.vmfpatrimoine.org/wp-content/uploads/2011/02/Rapport_C_DUMAS_metiers-dart-2009.pdf (acessed 5 February, 2015).

Vinciolo, Federico. Les singuliers et nouveaux pourtraicts. Stanley Applebaum, (trans.) New York: Dover Publications, 1971.

Vigarello, Georges. Le Propre et le Sale: L’hygiène du corps depuis le Moyen Âge. Paris: Éditions Seuil, 1985.

"Voeux du Congrès du Costume Régional à Nice," MNATP, Fonds Charles Brun, Boîte 14, Dossiers Divers: Le Costume Régional, "Articles de Journaux de 1914 à 1937." 
Walsh, Elizabeth C. "Gros point de Venise: Lace and its representation, 1660-1702." PhD diss., University of East Anglia, 2009.

Watt, Judith. Vogue on Schiaparelli. London: Quadrille Publishing Limited, 2012.

Wearden, Jennifer and Clare Browne. "Stitches and Techniques." In Samplers from the Victoria and Albert Museum, 129-135. London: V\&A Publications, 1999.

White, Palmer. Haute Couture Embroidery: the Art of Lesage. Paris: Vendome Press, 1998.

Young, Patrick. "Fashioning Heritage: Regional Costume and Tourism in Brittany, 1890-1937." Journal of Social History, Spring 2009, no. 42, 3, (2009).

Zola, E. Le Rêve. Paris: Bibliothèque-Charpentier, 1913. 